\title{
INFILTRAÇÃO MARGINAL EM RESTAURAÇÕES CLASSE V DE RESINA COMPOSTA: INFLUÊNCIA DA BASE E DA TÉCNICA DE FOTOATIVAÇÃO
}

\section{Nádia da Rocha Svizero}

Dissertação apresentada à Faculdade de Odontologia de Bauru, da Universidade de São Paulo, como parte dos requisitos para obtenção do título de Mestre em Odontologia, na área de Dentística.

(Edição Revisada)

Bauru

2003 


\section{INFILTRAÇÃO MARGINAL EM RESTAURAÇÕES \\ CLASSE V DE RESINA COMPOSTA: INFLUÊNCIA DA \\ BASE E DA TÉCNICA DE FOTOATIVAÇÃO}

\section{Nádia da Rocha Svizero}

Dissertação apresentada à Faculdade de

Odontologia de Bauru, da Universidade

de São Paulo, como parte dos requisitos

para obtenção do título de Mestre em

Odontologia, na área de Dentística.

Orientador: Prof. Dr. Mário Honorato da

Silva e Souza Júnior

Bauru

2003 


\section{Svizero, Nádia da Rocha}

Sv39i Infiltração marginal em restaurações classe $\mathrm{V}$ de resina composta: influência da base e da técnica de fotoativação / Nádia da Rocha Svizero. Bauru, 2003.

139p. : il.; $30 \mathrm{~cm}$

Dissertação (Mestrado) - Faculdade de Odontologia de Bauru. USP.

Orientador: Prof. Dr. Mário Honorato da Silva e Souza Júnior.

Autorizo, exclusivamente para fins acadêmicos e científicos, a reprodução total ou parcial desta dissertação, por processos fotocopiadores e outros meios eletrônicos.

Assinatura do autor: 


\section{Nádia da Rocha Svizero}

13 de setembro de 1974

São Paulo - S.P

$1992-1995$

$1996-1998$

$1997-2003$

$2001-2003$

Associações
Nascimento

Curso de Odontologia - Universidade do Sagrado Coração - Bauru - SP

Curso de Especialização em Dentística no Hospital de Reabilitação de Anomalias CrânioFaciais - Bauru (Centrinho - USP)

Professora da Disciplina de Dentística da Universidade do Sagrado Coração (USC) Bauru

Curso de Pós-Graduação em Dentística, nível de Mestrado, na Faculdade de Odontologia de Bauru, USP

GBPD - Grupo Brasileiro dos Professores de Dentística

IADR - International Association for Dental

Research

SBPqO - Sociedade Brasileira de Pesquisa

Odontológica 


\section{Dedico este trabalho:}

\section{A Deus,}

por permanecer ao meu lado e guiar os meus passos,

iluminar a minha vida e dar forças para vencer os obstáculos.

"A cada pôr do sol existem muitas razões para dizer: Obrigada, meu Deus, por suas dádivas, antes de tudo, por cada dia da minha vida".

\section{Aos meus pais Armando e Nadir}

Obrigada porque acreditaram que o amor gera a vida e por eu ser fruto dessa união...

Agradeço pelo incentivo, por tantos exemplos de humildade e honestidade;

pelos momentos em que juntos sofremos ou que felicidade partilhamos;

pelo amor incondicional com que sempre me acolheram; pelas preces nos momentos

de dificuldades e agradecimentos nas situações de alegria;

por partilharem comigo as conquistas e as derrotas;

pelas vezes que enxugaram as minhas lágrimas com palavras e gestos de carinho;

por acreditarem que eu venceria mais esta batalha...

\section{Ao meu irmão Vitor}

Obrigada pelo apoio e incentivo,

pelo carinho, amizade e solidariedade nos momentos que mais precisei.

Você é um irmão muito querido! 


\section{Ao Paulo}

Nesta Faculdade nossos destinos se cruzaram e o que inicialmente era amizade em amor se transformou...

Você que soube como me fazer feliz;

soube me ouvir e compreender,

participou e se alegrou,

acreditou e confiou.

Obrigada pela paciência e cumplicidade durante a fase de elaboração deste trabalho.

Agradeço o marido maravilhoso que você é, cuja força está em sua gentileza e compreensão; companheiro que me encorajou a ser tudo o que posso ser, que é meu consolo e alegria.

Obrigada, acima de tudo, pelos sonhos, esperanças e amor que juntos partilhamos.

Amo você !! 


\section{Agradecimentos Especiais}

\section{Ao meu orientador: Prof. Dr. Mário Honorato da Silva e Souza Júnior}

Agradeço pela compreensão e confiança, pois, mesmo à distância, acreditou no meu trabalho. Seus ensinamentos, humildade, apoio e orientação colaboraram para o meu crescimento. Muito obrigada!!!

\section{Ao Prof. Dr. Ricardo Marins de Carvalho}

Obrigada pelo exemplo de simplicidade, dignidade, generosidade e pela amizade transmitida. Agradeço pela oportunidade de aprendizado e por acreditar na minha capacidade. Sua dedicação e disponibilidade foram essenciais para o desenvolvimento deste trabalho.

Acima de tudo, muito obrigada pelo incentivo, confiança e por ter ajudado a transformar um grande sonho em realidade...

Palavras ou gestos jamais serão suficientes para expressar o meu carinho e admiração.

\section{À Prof. Dra. Maria Teresa Atta}

Obrigada pelo incentivo, auxílio e pela grande colaboração na execução deste trabalho. Obrigada por ter caminhado comigo, transmitindo grandes conhecimentos; por ser um verdadeiro exemplo de dedicação profissional e humildade pessoal. Seu carinho e incentivo iluminaram vários momentos da minha vida, com toques de amor e alegria.

"Agradeço a solidez da sua amizade e a ternura das suas palavras" 


\section{Meus Agradecimentos}

Aos professores do Departamento de Dentística: Mário Honorato da Silva e Souza Júnior, Carlos Eduardo Francischone, Ricardo Marins de Carvalho, Maria Teresa Atta, Eduardo Batista Franco, Áquira Ishikiriama, José Carlos Pereira, Maria Fidela de Lima Navarro, José Mondelli e Rafael Lia Mondelli

Verdadeiros exemplos de dedicação e sabedoria. Agradeço pela oportunidade de convivência e pelos ensinamentos que muito colaboraram para o meu crescimento profissional.

Ao Prof. Dr. Carlos Eduardo Francischone, pela confiança em mim depositada e pelo incentivo na carreira docente.

Ao Prof. Dr. José Carlos Pereira, pelo carinho com que sempre me recebeu e por todo ensinamento transmitido.

A Prof. Dra. Maria Fidela de Lima Navarro, diretora desta Faculdade, pela constante dedicação ao ensino e à pesquisa.

\section{Aos meus queridos amigos: Terezinha, Eduardo, Natália e Flávia}

Muito obrigada pela sincera amizade e pelas infinitas situações em que me auxiliaram para a realização deste trabalho.

Aos meus colegas do Mestrado: Terezinha, Natália, Eduardo, Bruno, Flávia, Luiz, Léo, Diego, Anuradha, Renato e Anderson; agradeço pelos momentos de convivência e pelas conquistas que juntos alcançamos.

Às minhas queridas amigas: Maria Teresa, Silvana, Cecília, Lucirene, Carol, Débora, Sueli e Cláudia - muito obrigada pela amizade, pelos momentos de descontração e por terem partilhado comigo esta caminhada de crescimento pessoal e profissional. Vocês são muito especiais!

À Universidade do Sagrado Coração, pelo incentivo e confiança em mim depositados. 
Aos demais amigos da Universidade do Sagrado Coração: Laerte, Renato, Leda, Sara, Ester e Myriam - agradeço por todos os momentos de solidariedade, amizade e compreensão. A paciência de vocês foi essencial para que este momento se realizasse.

Aos funcionários do Departamento de Dentística da FOB: Nelson, Júnior, Dito, Zuleica, Karen, Zilei, Rita, Ângela, Eloísa e Elisabeth - agradeço pelo carinho com que me receberam e por todas as ocasiões em que me auxiliaram.

Às minhas amigas Linda Wang e Fernanda Garcia, agradeço pela amizade, presença e incentivo nos momentos de alegrias e de dificuldades.

À Celiane e Fernanda Bijella, pelos momentos nos quais se dispuseram a me auxiliar, colaborando para a execução da parte prática deste estudo.

Ao Prof. José Roberto Lauris, pela dedicação e orientação na análise estatística dos resultados deste trabalho.

Aos funcionários da Pós-Graduação: Giane, Aurélio, Ana e Cleusa - obrigada pela paciência, carinho e dedicação.

Aos funcionários da Biblioteca, pela prontidão no atendimento e pelo carinho com que sempre me receberam.

À minha prima e amiga Graziele, pela ajuda na formatação deste trabalho e por partilharmos juntas cada momento de nossas vidas.

Aos meus avós, tios e primos: agradeço pelo incentivo e amor transmitidos, os quais diretamente colaboraram para a apresentação deste trabalho.

A todos os amigos que, direta ou indiretamente, torceram e acreditaram em mim. 
Nesta caminhada aprendi:

que se aprende, errando

que amigos conquistamos, mostrando o que somos

que verdadeiros amigos sempre ficam conosco até o fim

que quando penso saber de tudo, ainda não aprendi nada

que um só dia pode ser mais importante que muitos anos

que o que realmente importa é a paz interior

E, finalmente, aprendi que não se pode morrer, para se aprender a viver...

Cada dia é um novo começo, uma nova oportunidade para aprendermos mais sobre nós mesmos, nos importarmos mais com os outros, para rir mais do que antes, para realizar mais do que pensávamos que poderíamos, para ser mais do que éramos antes. 


\section{SUMÁRIO}

Lista de Abreviaturas e Símbolos ......................................................... xi

Lista de Figuras ....................................................................................

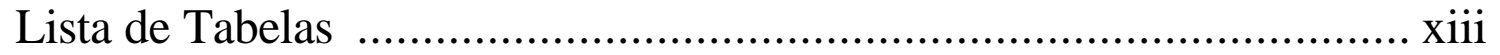

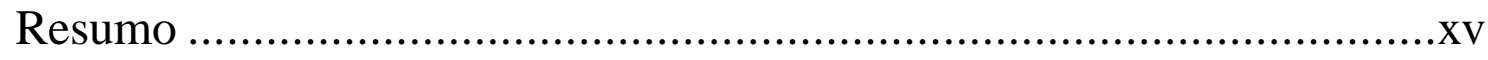

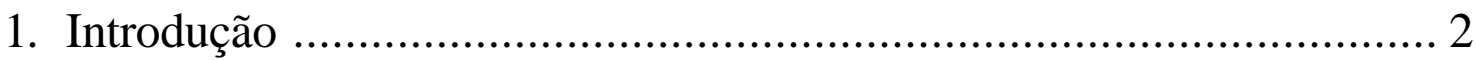

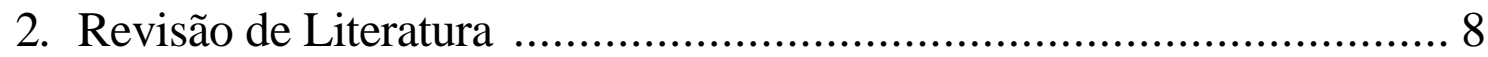

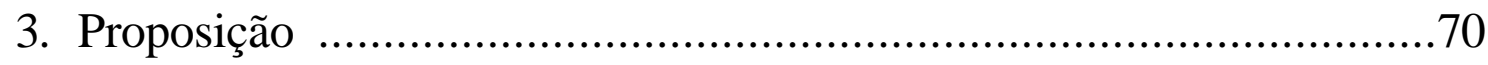

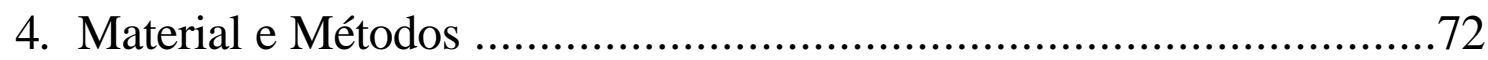

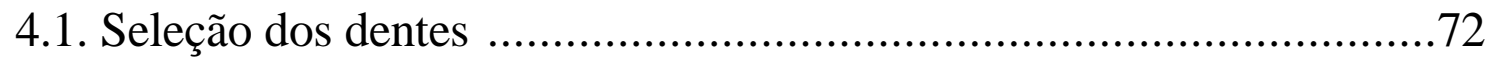

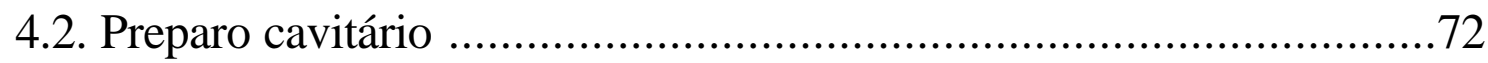

4.3. Materiais e procedimentos restauradores ........................................74

4.4. Ciclagem térmica e Infiltração por corante ......................................81

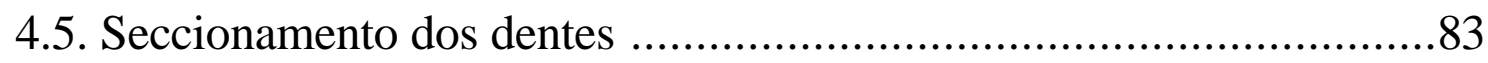

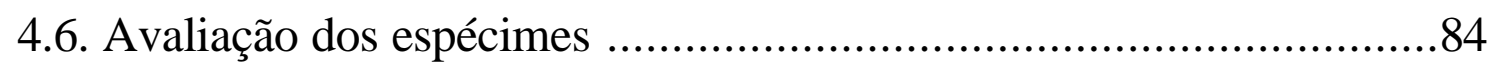

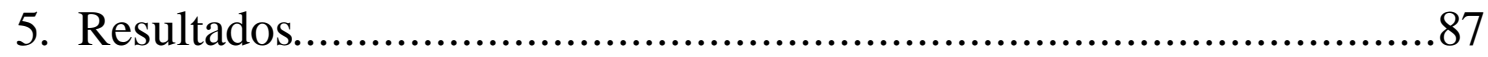

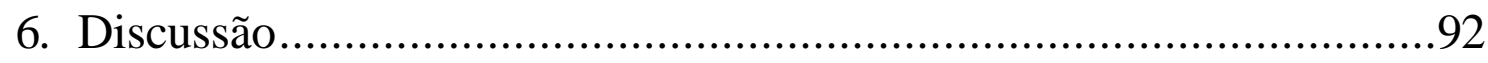

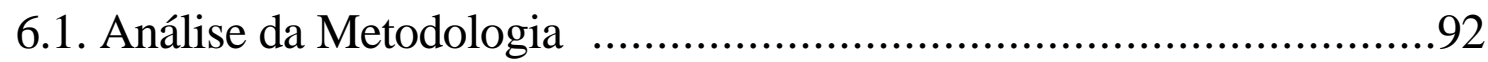

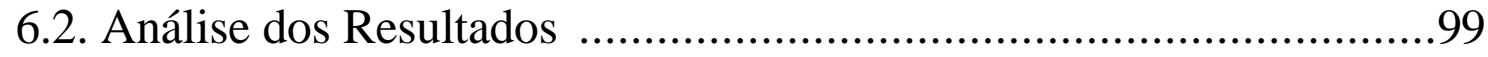

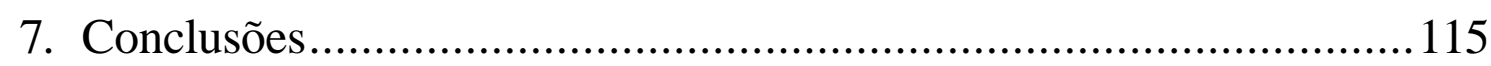

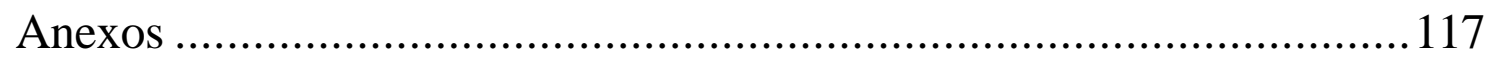

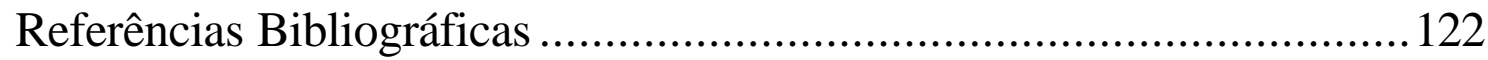

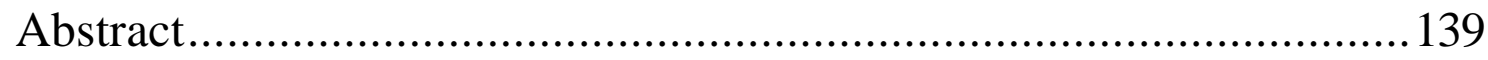




\section{LISTA DE ABREVIATURAS E SÍMBOLOS}

mm: milímetros

$\mathrm{cm}^{2}$ : centímetro quadrado

mW: miliWatt

$\mathrm{mW} / \mathrm{cm}^{2}$ : miliWatt por centímetro quadrado

${ }^{\circ} \mathrm{C}$ : grau Celsius

$\%:$ porcentagem

CET: coeficiente de expansão térmica

$\mathrm{RC}$ : resina composta

CIV: cimento de ionômero de vidro

CIVMR: cimento de ionômero de vidro modificado por resina

PVC: polivinit-chloridre

MEV: microscópio eletrônico de varredura

$\mu \mathrm{m}$ : micrômetro

MOD: mésio-ocluso-distal

s: segundos

MPa: Mega Pascal

nm: nanômetro 


\section{LISTA DE FIGURAS}

Figura 1 - Dentes incisivos inferiores bovinos selecionados para a pesquisa 73

Figura 2 - Desenho esquemático das dimensões do preparo cavitário .73

Figura 3 - Preparo cavitário 73

Figura 4 - Materiais utilizados no estudo 74

Figura 5 - Aparelhos fotopolimerizadores Optilight Digital e Apollo 95E.... 75

Figura 6 - Aparelhos fotopolimerizadores Elipar Trilight E VIP .75

Figura 7 - Representação esquemática: A base de cimento de ionômero de vidro/ resina composta; B- resina composta

Figura 8 - Máquina utilizada para ciclagem térmica dos espécimes 82

Figura 9 - Diferenciação entre os grupos experimentais (A) com exposição da interface adesiva (B) .82

Figura 10 - Inclusão dos espécimes em tubos de PVC .83

Figura 11 - Espécime incluído em resina epóxica 83

Figura 12 - Seccionamento longitudinal dos espécimes para obtenção dos cortes 84

Figura 13 - Escaneamento do corte de maior infiltração, juntamente com uma régua milimetrada .85

Figura 14 - Distribuição das médias de infiltração marginal (mm) das técnicas de fotoativação em função da base utilizada .88

Figura 15 - Distribuição das médias de infiltração marginal $(\mathrm{mm})$ das bases em função da técnica de fotoativação utilizada. 88

Figura 16 - Penetração do corante pela interface adesiva não ultrapassando a base de ionômero de vidro 112

Figura 17 - Padrão de infiltração marginal em relação à disposição dos túbulos dentinários.... 


\section{LISTA DE TABELAS}

Tabela 1 - Materiais utilizados na pesquisa 74

Tabela 2 - Procedimentos restauradores realizados nos diferentes grupos experimentais .....76

Tabela 3 - Técnicas de fotoativação e intensidades de luz emitidas pelos diferentes aparelhos fotopolimerizadores 80

Tabela 4 - Médias das infiltrações marginais (mm) e desvio padrão dos grupos experimentais em função da técnica de fotoativação e base 87

Tabela 5- Análise de Variância a dois critérios para comparação entre técnica de fotoativação e base 89

Tabela 6 - Médias e desvio padrão dos valores de infiltração marginal para as técnicas de fotoativação ao nível de significância de $5 \%$ .89

Tabela 7 - Médias e desvio padrão dos valores de infiltração marginal para as bases de cimento de ionômero de vidro ao nível de significância de 5\% .90 


\section{RESUMO}

Avaliou-se a infiltração marginal em cavidades classe $\mathrm{V}$ restauradas com resina composta, utilizando-se diferentes bases de cimentos de ionômero de vidro e diferentes técnicas de fotoativação. As cavidades foram confeccionadas na face vestibular da raiz de 120 dentes bovinos, apresentando $4 \mathrm{~mm}$ de altura, $3 \mathrm{~mm}$ de largura e $1,5 \mathrm{~mm}$ de profundidade. Os dentes foram divididos em 12 grupos, de acordo com o tipo de base (cimento de ionômero de vidro modificado por resina ou convencional) e com a técnica de fotoativação (convencional, rampa, pulso e alta intensidade). Grupos 1, 4, 7 e 10- Single Bond + Z100; grupos 2, 5, 8 e 11- CIVMR (Vitrebond) + Single Bond + Z100; grupos 3, 6, 9 e 12- CIV convencional (Ketac Bond) + Single Bond + Z100. Os grupos 1, 2 e 3 foram fotoativados pela técnica convencional e os demais grupos pelas técnicas em rampa $(4,5$ e 6$)$, por pulso $(7,8,9)$ e alta intensidade $(10,11,12)$. A base de cimento de ionômero de vidro apresentou-se com $0,5 \mathrm{~mm}$ de espessura e a resina composta foi inserida em um único incremento. As técnicas de fotoativação, com diferentes intensidades de luz, foram empregadas da seguinte forma: $450 \mathrm{~mW} / \mathrm{cm}^{2}$ por $40 \mathrm{~s}$ (convencional), 100 a $800 \mathrm{~mW} / \mathrm{cm}^{2}$ por $15 \mathrm{~s}+800 \mathrm{~mW} / \mathrm{cm}^{2}$ por $25 \mathrm{~s}$ (rampa); $200 \mathrm{~mW} / \mathrm{cm}^{2}$ por $3 \mathrm{~s}+3$ minutos espera $+30 \mathrm{~s} \mathrm{a} 600 \mathrm{~mW} / \mathrm{cm}^{2}$ (pulso); $1600 \mathrm{~mW} / \mathrm{cm}^{2}$ por 3s (alta intensidade). Após o acabamento e polimento das restaurações, os espécimes foram submetidos à termociclagem $\left(500\right.$ ciclos a $5^{\circ} \mathrm{C}$ e $55^{\circ} \mathrm{C}, 60 \mathrm{~s}$ em cada banho) e imersos em fucsina básica a $0,5 \%$ por $4 \mathrm{~h}$. As restaurações foram seccionadas e, após a seleção do corte de maior infiltração, as imagens foram digitalizadas para a avaliação da penetração do corante, em milímetros, através do programa de computação Image Tool. A análise estatística, realizada pela ANOVA a dois critérios e pelo teste de Tukey, não mostrou diferença estatisticamente significativamente entre as técnicas de fotoativação convencional e graduais (rampa e pulso). A técnica de alta intensidade revelou maior infiltração marginal, quando comparada às técnicas convencional, rampa e pulso. Não foi observada diferença significante entre as duas bases de cimento de ionômero de vidro utilizadas, porém, na sua ausência, observaram-se índices significativamente maiores de infiltração. Concluiu-se que as técnicas de fotoativação gradual (rampa e pulso) não foram capazes de minimizar a infiltração marginal, quando comparadas à técnica convencional. A utilização de uma base de cimento de ionômero de vidro sob a resina composta minimiza a infiltração marginal, enquanto que o emprego da técnica de fotoativação com alta intensidade de luz proporciona uma maior 
infiltração, não contribuindo para uma adequada integridade marginal em restaurações classe $\mathrm{V}$ de resina composta, com margens localizadas em dentina. 
1 - INTRODUÇÃO 


\section{1 - INTRODUÇÃO}

Desde a sua introdução na década de 70 , as resinas compostas fotopolimerizáveis, juntamente com os sistemas adesivos, revolucionaram a Odontologia restauradora, devido à contínua evolução na sua composição, resultando em uma melhora nas propriedades mecânicas e no resultado estético. O aprimoramento das propriedades mecânicas foi proporcionado pelas modificações realizadas na composição, tipo, formato e quantidade de carga inorgânica, bem como na parte orgânica, proporcionando a este material um bom desempenho clínico ${ }^{71}$.

Apesar da constante evolução, as resinas compostas ainda apresentam limitações, tais como baixa resistência ao desgaste e contração de polimerização ${ }^{3,70,84,115}$. A contração é uma característica inerente às resinas compostas e ocorre durante a polimerização destes materiais $^{21,157}$, através de uma aproximação molecular que acontece para a formação da cadeia polimérica, o que é representado na prática por uma diminuição no volume da restauração ${ }^{132}$. Assim, quanto maior a conversão dos monômeros em polímeros, maior a contração de polimerização $^{113}$.

Dependendo da magnitude da força gerada por esta contração, a possível ruptura das ligações adesivas existentes entre a estrutura dentária e o ma terial restaurador poderá resultar em falhas adesivas e na formação de fendas marginais ${ }^{23,52,57,108,132}$. Desta forma, a contração de polimerização das resinas compostas pode comprometer a adaptação marginal da restauração, originando aberturas microscópicas nas margens cavitárias e permitindo a passagem de bactérias, fluidos, substâncias químicas, moléculas e íons, definida como microinfiltração ${ }^{1,68,131,146}$.

Esta infiltração acontece com maior freqüência na parede cervical de restaurações classe $\mathrm{V}^{6,32,58,80,83,85,106,125}$, principalmente onde há ausência de esmalte. A localização das margens cavitárias em dentina ou cemento pode acarretar em um maior potencial para a infiltração marginal ${ }^{128}$, devido às variações regionais de morfologia e fisiologia deste substrato, determinando uma não uniformidade de adesão ${ }^{22,62,79}$. Além destes fatores, a concentração de esforços na interface dente-restauração é relevante, uma vez que a rigidez relativamente alta da estrutura dentária e das resinas compostas dificulta a assimilação das tensões geradas durante a contração de polimerização ${ }^{132}$. Desta maneira, um adequado vedamento marginal é requerido, principalmente nesses tipos de cavidades, pois a sua falha 
pode contribuir para a ocorrência de infiltração marginal, sensibilidade pós-operatória e cárie secundária ${ }^{93}$.

Alguns fatores podem minimizar os efeitos da contração de polimerização, atenuando a geração de tensões na interface adesiva, tais como a utilização de bases cavitárias, como o cimento de ionômero de vidro, e a modulação da fotoativação, a qual permite que as moléculas busquem um posicionamento mais favorável durante a polimerização, diminuindo a tensão interna no material e na interface ${ }^{45,132}$. Outro fator a ser analisado é a configuração cavitária, pois quanto menor a relação existente entre o número de superfícies aderidas e de superfícies livres voltadas para a fonte polimerizadora, maior a facilidade de relaxamento das tensões oriundas da contração de polimerização, favorecendo, assim, a interface adesiva $^{23,45,132}$. A técnica de inserção incremental da resina composta também favorece o relaxamento do material pelo aumento da área de superfície livre do mesmo, devendo-se considerar ainda que, quanto maior o seu volume, maior a contração e seus possíveis efeitos $^{45,132}$.

A busca por materiais que proporcionassem menor infiltração marginal e boa retenção levou ao emprego dos cimentos de ionômero de vidro sob restaurações de resina composta, sendo a utilização desses materiais proposta por diversos autores ${ }^{9,41,59,64,65,80,83,93,100,125,144,146}$, principalmente em cavidades com margens localizadas abaixo da junção amelocementária ${ }^{87,101,130}$. A associação do cimento de ionômero de vidro à resina composta foi proposta devido às suas características de adesividade ao esmalte e à dentina ${ }^{96,130,146}$, biocompatibilidade $^{92,96}$, liberação de flúor na interface e margens da restauração ${ }^{86,92,96}$ e baixo coeficiente de expansão térmica linear, o que favorece a estabilidade do material ${ }^{83,96,125}$. A utilização de uma camada intermediária ${ }^{81}$ com um material de baixo módulo de elasticidade ${ }^{34}$, ou seja, de maior resiliência, como os cimentos ionoméricos, permitiria um alívio das tensões provenientes da contração de polimerização ${ }^{51}$ e também daquelas oriundas da própria mastigação. Por esses motivos, a técnica mista tem sido bastante utilizada e difundida ${ }^{8,9,59,64,80,125,146}$.

A capacidade adesiva dos cimentos de ionômero de vidro convencionais à dentina deve-se, em parte, a um processo dinâmico de troca iônica entre o material e a estrutura dentária. Porém, esses materiais apresentam desvantagens como curto tempo de trabalho, longo tempo de presa, sensibilidade técnica e suscetibilidade à contaminação precoce ${ }^{26}$.

Com o objetivo de superar tais limitações, mas preservando as boas propriedades do material, surgiram os cimentos de ionômero de vidro modificados por resina, os quais 
apresentam estética e propriedades mecânicas melhoradas, além de proporcionarem um maior tempo de trabalho e controle do tempo de presa ${ }^{26,128,144}$. Nestes materiais, denominados híbridos, ocorre tanto a reação ácido-básica quanto uma reação fotoativada de polimerização dos radicais livres ${ }^{26}$, conferindo uma retenção micromecânica ${ }^{55}$ pela presença de componentes resinosos na sua composição. Algumas pesquisas têm mostrado superioridade desses materiais em relação aos convencionais no que se refere à infiltração marginal, ${ }^{9}{ }^{144}$, enquanto outras não demonstram diferença entre ambos ${ }^{17,55,130}$. Contudo, apesar de vários estudos mostrarem que os cimentos de ionômero de vidro reduzem o problema da microinfiltração, são ainda incapazes de impedi-la completamente 9 9,32,47,58,80,93,125,133,134,146.

Adicionalmente à introdução de novos materiais restauradores, novas técnicas de fotoativação, utilizando diferentes intensidades de luz, foram propostas como meios eficazes de diminuir a contração de polimerização e a conseqüente infiltração marginal.

Para reduzir o tempo clínico despendido e aumentar a velocidade do processo de polimerização da resina composta, além dos tradicionais sistemas de luz halógena, fontes que utilizam alta intensidade de luz (aproximadamente de $1.440 \mathrm{~mW} / \mathrm{cm}^{2}$ a $2.400 \mathrm{~mW} / \mathrm{cm}^{2}$ ) foram introduzidas no mercado, diferenciando-se pelo tipo de fonte de energia, variação na faixa do comprimento de onda e intensidade de luz que emitem ${ }^{12,16,27,28,35,113}$. Esses aparelhos, denominados de arco plasma de xenônio, têm sido avaliados sob vários aspectos, inclusive quanto ao grau de contração que induzem na resina composta e à conseqüente integridade marginal que proporcionam ${ }^{16,25,103,137}$, uma vez que ocorre uma rápida polimerização em um curto tempo de irradiação. Apesar do aumento na velocidade de polimerização, a literatura relata que altas intensidades de luz induzem ao aumento da tensão interna do material restaurador e à conseqüiente infiltração marginal ${ }^{70,148}$. No entanto, a discussão passa a ser mais complexa, à medida que outros autores não observaram danos na integridade marginal quando da utilização de altas intensidades de luz ${ }^{61}$.

A ruptura das ligações adesivas pode ocorrer mediante uma rápida reação de polimerização, podendo esta também ser induzida pela técnica de fotoativação constante, geralmente realizada por aparelhos convencionais (lâmpadas halógenas de quartzotungstênio), com intensidades de luz em torno de 400 a $650 \mathrm{~mW} / \mathrm{cm}^{2}$ 46,70,75,131. Assim, uma redução na velocidade de polimerização, através do controle da intensidade de luz durante os estágios iniciais da reação, poderia contribuir para uma melhor adaptação marginal das resinas compostas às paredes cavitárias ${ }^{157}$. 
Uma reação de polimerização mais lenta pode ser realizada através do controle da fotoativação, iniciando-se a mesma com uma baixa intensidade de luz e completando o processo com alta intensidade ${ }^{15,27,50,57,66,70,88,119,132,147}$. Este procedimento, conhecido como técnica de fotoativação gradual, além de propiciar melhores resultados de adaptação marginal, mantém as propriedades mecânicas do material ${ }^{38,57,70,72,88,147,148}$. Assim, se a intensidade de luz for reduzida inicialmente, um menor número de radicais livres serão formados e, conseqüentemente, a reação de polimerização será mais lenta, prolongando o escoamento do material e reduzindo os efeitos da contração ao nível da interface adesiva ${ }^{76,113,132}$. Quando o material alcançar o ponto gel, momento a partir do qual não pode mais dispor do escoamento viscoso, ou seja, torna-se rígido ${ }^{113}$, a resina poderá ser submetida à alta intensidade de luz, para que atinja o grau de conversão necessário para suportar as exigências mecânicas a que será submetida.

Nos últimos anos, os fabricantes têm produzido aparelhos fotoativadores com programas que permitem o escalonamento da intensidade de luz, possibilitando a utilização de diferentes técnicas graduais de fotoativação ${ }^{28}$. As mais conhecidas e divulgadas são: em passos, em rampa e em pulsos ${ }^{113}$. O aumento da intensidade em passos significa que uma dose reduzida de potência é disponibilizada, por um determinado período, para a superfície da resina. Logo em seguida, o aparelho eleva essa potência para níveis máximos, que são mantidos até o final do ciclo. Na técnica em rampa, há o aumento gradual da intensidade de luz até atingir o nível máximo, o qual também se mantém por um determinado período, até que o grau de conversão total seja alcançado. Por último, o aumento da potência em pulsos, também denominado de pulso tardio, implica na emissão de uma dose reduzida de luz por alguns segundos (3-5 segundos), seguida de um período de espera (3-5 minutos), para, em seguida, expor a resina composta à máxima potência de luz, completando a reação de conversão ${ }^{113}$. Como visto, são inúmeras as alternativas para diminuir a velocidade da reação de polimerização. É importante entender que o princípio básico é a redução inicial da densidade de potência, seguida de uma elevação a níveis adequados, para assegurar um satisfatório grau de conversão do material ${ }^{147}$ e obtenção de uma melhor qualidade marginal.

Esses novos conceitos de fotoativação, associados à utilização de materiais de baixo módulo de elasticidade, sob restaurações de resina composta, especialmente em cavidades com margens em dentina, têm permitido ao profissional a escolha por diferentes procedimentos clínicos. Contudo, é necessária a execução de pesquisas para elucidar o 
método ou a associação de técnicas mais eficientes para a obtenção de um adequado vedamento na interface dente-restauração.

Assim, considerando que a contração de polimerização pode ser influenciada pela presença de uma base elástica no fundo cavitário e pela modulação da fotoativação, objetivouse avaliar a infiltração marginal em restaurações classe $\mathrm{V}$ de resina composta, utilizando-se diferentes bases de cimento de ionômero de vidro e diferentes técnicas de fotoativação. 


\section{2 - REVISÃO DE LITERATURA}

$\boldsymbol{K I D D}^{68}$, em 1976, definiu microinfiltração como a passagem de bactérias, fluidos, moléculas ou íons entre a parede cavitária e o material restaurador, o que pode resultar em problemas tais como descoloração marginal, hipersensibilidade e aparecimento de cáries secundárias. Dentre as técnicas desenvolvidas para avaliar a infiltração marginal, a autora citou a utilização de corantes, isótopos radioativos, ar comprimido, uso de bactérias, análise de ativação de nêutrons, cáries artificiais, microscopia eletrônica de varredura e ciclagem térmica. O emprego de corantes orgânicos foi definido como o método mais antigo, porém o mais comumente utilizado para a detecção da microinfiltração. Comentou que a percolação marginal decorre, provavelmente, da diferença de coeficiente de expansão térmica entre o dente e o material restaurador, justificando a importância das variações de temperatura na adaptação marginal. Assim, os procedimentos de ciclagem térmica são utilizados, apresentando geralmente ciclos com temperaturas de $4^{\circ} \mathrm{C}$ e $60^{\circ} \mathrm{C}$ ou $15^{\circ} \mathrm{C}$ e $45^{\circ} \mathrm{C}$, enquanto que o tempo de imersão nos banhos pode variar de segundos a horas, sendo que muitas pesquisas utilizam tempos de 30 ou 60 segundos. Afirmou que os testes laboratoriais que analisam a microinfiltração são de suma importância para a avaliação dos materiais, contudo os testes in vivo são considerados ainda os que apresentam maior fidelidade.

Os mesmos métodos para a análise da microinfiltração foram também descritos por SHORTALL ${ }^{126}$, em 1982, através de uma revisão de literatura. O autor enfatizou que diversas técnicas podem ser utilizadas para avaliar a adaptação marginal dos materiais restauradores às paredes cavitárias, dentre eles: imersão em substâncias corantes, marcadores químicos, traçadores radioativos, ar pressurizado, cárie artificial, análise de ativação de nêutron, microscopia eletrônica de varredura, ciclagem térmica ou mecânica. Quanto ao teste laboratorial, onde se utilizam corantes orgânicos para o traçado da infiltração, foi considerado que, apesar de ser um dos métodos mais antigos, também é um dos mais utilizados pelos pesquisadores devido à facilidade que propicia. $\mathrm{O}$ autor comentou que a desvantagem inerente a esse teste é a sua subjetividade no momento da quantificação da infiltração, já que é baseado em valores pré-determinados (escores). Citou que as temperaturas utilizadas na literatura durante a ciclagem térmica apresentam-se entre $0^{\circ} \mathrm{C}$ e $68^{\circ} \mathrm{C}$; o tempo de imersão pode variar de segundos a horas e a quantidade de ciclos de 1 a 5000. Considerou ainda a importância dos testes laboratoriais para a determinação da microinfiltração, até que as possíveis causas e 
conseqüências da mesma possam ser melhor definidas, podendo ou ño serem confirmadas posteriormente através dos testes in vivo.

Buscando-se um possível substituto para os dentes humanos nos testes de adesão, a força adesiva entre dentes humanos e bovinos foi comparada por NAKAMICHI; IWAKU; FUS $\boldsymbol{A} \boldsymbol{Y} \boldsymbol{A} \boldsymbol{A} \boldsymbol{A}^{95}$, em 1983, utilizando-se três cimentos de policarboxilato, um cimento de ionômero de vidro, um fosfato de zinco e duas resinas compostas. Nos dentes humanos, as superfícies de esmalte e dentina foram aplainadas, obtendo-se áreas somente em dentina superficial, enquanto que, nos dentes bovinos, ambos os substratos foram aplainados, expondo-se áreas em dentina superficial e profunda. Assim, avaliaram a adesão com relação à profundidade e ao tempo de armazenamento, utilizando dentes recém-extraídos com pouco mais que cinco dias e armazenados a mais de seis meses. Após a obtenção dos espécimes, os mesmos foram submetidos aos testes de resistência à tração. Observaram que a resistência adesiva ao esmalte e à camada superficial da dentina não se apresentou estatisticamente diferente entre dentes bovinos e humanos, contudo as médias encontradas nos dentes bovinos foram ligeiramente menores nas duas situações. A adesão à dentina bovina diminuiu consideravelmente com o aumento da profundidade e dentes com maior tempo de armazenamento mostraram maior adesão a este substrato, quando comparados aos dentes recém-extraídos. Concluíram que os dentes bovinos podem ser utilizados como substitutos aos dentes humanos nos testes de adesão, desde que seja avaliado o esmalte ou a camada superficial da dentina.

Em 1985, GORDON et al. $^{58}$ compararam a infiltração marginal em restaurações de resina composta, inseridas sobre uma base de ionômero de vidro, em cavidades de classe $\mathrm{V}$. Selecionaram-se vinte molares humanos extraídos e os preparos foram realizados na face vestibular e lingual de cada dente. Um pré-tratamento com ácido poliacrílico a $40 \%$ foi feito nas superfícies internas das cavidades e, posteriormente, o cimento de ionômero de vidro convencional Ketac Bond foi aplicado nas paredes axial e cervical, deixando-se o cavosuperficial gengival exposto. Após o condicionamento ácido do esmalte e do cimento de ionômero de vidro, e aplicação do sistema adesivo, os dentes foram divididos em quatro grupos de acordo com o tipo de resina composta a ser utilizada: Herculite, Prisma Fil, Silux, Visio Fil. Posteriormente, os dentes foram termociclados e imersos em solução de nitrato de prata. Em todos os grupos foi encontrada menor penetração do corante nas margens oclusais, 
quando comparada às margens gengivais. Segundo os autores, uma explicação para este fato seria que a contração de polimerização e a expansão térmica da resina composta e do ionômero de vidro podem ter excedido a capacidade de adesão dentinária, aumentando, desta forma, as fendas marginais, especialmente nas margens localizadas em dentina. Apesar de todos os materiais testados apresentarem infiltração, a combinação Ketac Bond/ Silux mostrou significante menor microinfiltração nas margens cervicais e oclusais. No entanto, os espécimes não apresentaram infiltração entre o ionômero de vidro e a resina composta. Os autores concluíram que a utilização do ionômero de vidro sob a resina composta é importante, uma vez que a ocorrência de infiltração nas margens dentinárias é mais freqüente.

CRIM; CHAPMA $\boldsymbol{N}^{31}$, em 1986, avaliaram a infiltração marginal em cavidades de classe V, com margens localizadas em esmalte ou dentina, utilizando-se duas diferentes técnicas restauradoras. Foram realizados preparos cavitários em 40 dentes, onde, nas faces vestibulares, as margens localizaram-se em esmalte, enquanto que as margens dos preparos linguais foram estendidas abaixo da junção amelo-cementária. Os dentes foram restaurados em incremento único ou em dois incrementos, com uma resina composta de micropartículas. Após a restauração, os espécimes foram submetidos à ciclagem térmica (1.500 ciclos) e imersos em fucsina básica por 24 horas. Cada dente foi seccionado longitudinalmente no centro das restaurações e a infiltração foi analisada através de escores. Observoutse que ambas as técnicas de inserção da resina composta (incremental e única) não diferiram significativamente, entretanto, a técnica de incremento único apresentou tendência a um menor grau de infiltração marginal. De acordo com os autores, a inserção incremental não é mais efetiva em minimizar a infiltração cervical, quando comparada com a técnica que utiliza um único incremento.

Em 1987, CRIM; SHA $\boldsymbol{Y}^{32}$ testaram se a presença de uma base de ionômero de vidro, sob restaurações de resina composta em cavidades de classe V, mostra-se eficaz no controle da infiltração marginal. Os preparos foram confeccionados no terço cervical das faces vestibulares e linguais de molares humanos, com margens gengivais localizadas abaixo da junção amelo-cementária. Selecionaram-se 10 dentes, que foram divididos em dois grupos de cinco e restaurados da seguinte forma: (1) base de ionômero de vidro Ketac Bond/ Visiobond/ Visio-Fil; (2) base de Ketac Bond/ Scotchbond/ Silux; (3) Visio-Bond/ Visio-Fil; (4) Scotchbond/ Silux; (5) Ketac Bond como material restaurador. Os dentes restaurados foram 
armazenados em água por 24 horas e submetidos a 100 ciclos de termociclagem nas temperaturas de $37^{\circ} \mathrm{C}(23 \mathrm{~s}), 12^{\circ} \mathrm{C}(4 \mathrm{~s}), 37^{\circ} \mathrm{C}(23 \mathrm{~s})$ e $54^{\circ} \mathrm{C}(4 \mathrm{~s})$. Em seguida, foram colocados em solução de fucsina básica por 24 horas e seccionados longitudinalmente no centro das restaurações para a avaliação da infiltração, através de um microscópio com 50X de aumento. Os resultados revelaram que o Scotchbond reduziu significativamente a infiltração nas margens dentinárias, comparado ao Visiobond. O ionômero de vidro Ketac Bond não resistiu à microinfiltração, quando utilizado como material restaurador, e foi ineficaz em prevenir maiores infiltrações em associação ao adesivo Visio-Bond, apresentando severa infiltração na margem gengival. Assim, o cimento de ionômero de vidro não foi capaz de prevenir a infiltração marginal quando utilizado conjuntamente com o sistema adesivo, concluindo-se que a redução da microinfiltração foi uma função exclusiva do sistema adesivo e não da base de ionômero de vidro.

Mediante estudos prévios, os quais sugerem que uma das formas de controlar ou reduzir a microinfiltração na interface adesiva é através da utilização de materiais com baixo coeficiente de expansão térmica, BULLARD; LEINFELDER; RUSSEL ${ }^{18}$ propuseram, em 1988, a estudar a relação existente entre a extensão de microinfiltração e o coeficiente de expansão térmica de diferentes materiais, quando submetidos a mudanças de temperatura. Cavidades de classe V foram preparadas na superfície vestibular de 60 molares humanos, com margens em esmalte e seis materiais, com diferentes coeficientes de expansão térmica, foram selecionados para a restauração das mesmas (ionômero de vidro, amálgama, resina composta posterior, óxido de zinco e eugenol, resina composta de micropartículas, resina acrílica). Os dentes restaurados foram termociclados em solução de fucsina básica a $0,5 \%$, em banhos de 1 minuto a $5^{\circ} \mathrm{C}$ e $55^{\circ} \mathrm{C}$ (125 ciclos). Após o seccionamento dos espécimes, os resultados demonstraram diferença significante entre os materiais, considerando que o cimento de ionômero de vidro foi o que apresentou menor infiltração marginal. Os autores relataram que quanto maior a diferença de coeficiente de expansão térmica entre dente e material restaurador, maior a pressão exercida na interface. Assim, concluíram que existe uma forte correlação entre coeficiente de expansão térmica e grau de microinfiltração. O cimento de ionômero de vidro é capaz de reduzir a infiltração marginal devido ao seu baixo coeficiente de expansão térmica, além de minimizar o aparecimento de cáries secundárias pela liberação de flúor. Assim, o coeficiente de expansão térmica deve ser considerado como um dos fatores responsáveis pela infiltração diante de outros a serem analisados. 
A infiltração marginal em cavidades de classe $\mathrm{V}$, restauradas com diferentes resinas compostas inseridas sobre diferentes bases de cimentos de ionômero de vidro, foi avaliada por GARCIA-GODOY; MALONE ${ }^{53}$, em 1988. Os preparos foram realizados nas faces vestibulares e linguais de 30 molares humanos, com margens localizadas em esmalte. Para a realização dos procedimentos restauradores, os dentes foram divididos em 6 grupos experimentais, com 5 dentes cada (10 restaurações), utilizando-se duas marcas comerciais de resinas compostas e duas diferentes bases de ionômero de vidro. Os grupos 1 e 4 foram restaurados somente com as resinas compostas Fulfil e Occlusin; os grupos 2 e 5 com base de cimento de ionômero de vidro GC Lining e resina composta Fulfil ou Occlusin; os grupos 3 e 6 com base de ionômero de vidro Ketac Bond e resina composta Fulfil ou Occlusin. Os dentes foram posteriormente submetidos à ciclagem térmica e imersos em solução corante de fucsina básica por 24 horas. O corte longitudinal pelo centro das restaurações não demonstrou infiltração na margem oclusal em nenhum dos espécimes, entretanto algumas amostras exibiram infiltração na margem cervical, fato este atribuído a possível presença de esmalte aprismático nesta região. A utilização do cimento de ionômero de vidro não foi capaz de impedir a microinfiltração, contudo os autores concluíram que a utilização deste material sob a resina composta pode prevenir ou minimizar as cáries secundárias, devido à liberação de flúor que proporciona.

SCHWARTZ; ANDERSON; PELLEU ${ }^{125}$, em 1990, verificaram a infiltração na margem gengival de restaurações do tipo sanduíche (ionômero de vidro + resina composta) em cavidades de classe $\mathrm{V}$, utilizando diferentes técnicas de inserção da resina composta. Os resultados foram comparados com restaurações realizadas somente com resina composta (grupo controle). As cavidades foram confeccionadas nas faces vestibulares e linguais de 44 molares humanos, com margens acima e abaixo da junção amelo-cementária. Dividiram-se os preparos em dois grupos, onde primeiramente a superfície dentinária foi condicionada com o líquido do Durelon (ESPE) por 10 segundos, para posterior aplicação do cimento de ionômero de vidro convencional Ketac Bond (ESPE). Em um grupo, a resina composta de micropartículas (Silux) foi inserida em um único incremento e, no outro grupo, em dois incrementos. As cavidades do grupo controle foram restauradas somente com duas camadas de resina composta. Os dentes foram armazenados a $37^{\circ} \mathrm{C}$ por 24 horas e as restaurações polidas, permanecendo, posteriormente, em solução salina por mais 14 dias. Os espécimes foram submetidos a 400 ciclos de ciclagem térmica a $5^{\circ} \mathrm{C}$ e $55^{\circ} \mathrm{C}$, com 30 segundos em cada 
banho. A seguir, foram imersos em nitrato de prata e seccionados longitudinalmente para avaliação através de escores. Os resultados mostraram que as restaurações realizadas com ionômero de vidro e resina composta infiltraram significativamente menos que as restaurações do grupo controle, contudo diferença significante não foi observada entre os dois tipos de restaurações sanduíche. Através deste estudo, os autores concluíram que não há diferença entre a inserção única da resina composta ou em dois incrementos, quando se associam o ionômero de vidro e a resina composta. A utilização conjunta desses dois materiais torna-se uma opção restauradora eficaz em lesões localizadas abaixo da junção amelo-cementária, devido à redução da microinfiltração, ao potencial cariostático e ao benefício estético que proporcionam.

O propósito do estudo de HOLTAN et al ${ }^{65}$, em 1990, foi examinar e comparar a microinfiltração de restaurações de resina composta em cavidades de classe V, utilizando uma base de cimento de ionômero de vidro fotopolimerizável, a qual foi aplicada até ou aquém da margem cavo-superficial. Os preparos cavitários foram confeccionados nas faces opostas de trinta e um molares extraídos, localizados abaixo e acima da junção amelo-cementária. Um preparo foi utilizado como controle e outro como experimental. No primeiro grupo, aplicourse o cimento de ionômero de vidro Vitrabond (3M), estendendo-se o mesmo até a margem cavosuperficial e, no segundo, este material foi aplicado aquém da margem. Em seguida, o esmalte foi condicionado, o sistema adesivo Scotchbond 2 aplicado e a resina composta Silux Plus inserida em um único incremento. Os dentes foram termociclados a $5^{\circ} \mathrm{C}$ e $55^{\circ} \mathrm{C}$, por 1 minuto em cada banho, totalizando 500 ciclos. Após a imersão em nitrato de prata por 2 horas, os espécimes foram seccionados para separar os dois grupos e reseccionados no centro das restaurações para análise dos resultados. A colocação da base de cimento de ionômero de vidro até o cavo-superficial não melhorou a microinfiltração, quando comparado ao grupo que o utilizou aquém da margem. Considerando o potencial à fratura do cimento de ionômero de vidro quando exposto ao meio bucal, os autores recomendaram a utilização deste material aquém da margem cavo-superficial associado à resina composta.

MATHIS et al. ${ }^{83}$, em 1990, avaliaram o selamento marginal quando o cimento de ionômero de vidro foi utilizado sob a resina composta, em cavidades de classe V. Doze molares humanos foram selecionados e os preparos foram realizados na face vestibular e lingual de cada dente, com as margens oclusal e cervical localizadas em esmalte e dentina, 
respectivamente. Em cada dente, um dos preparos foi restaurado com cimento de ionômero de vidro e resina composta e outro somente com resina composta. Os dentes foram termociclados em temperaturas de $5^{\circ} \mathrm{C}$ e $55^{\circ} \mathrm{C}$ em banhos de 1 minuto, perfazendo um total de 1.700 ciclos. Após o vedamento, os dentes foram imersos em azul de metileno, lavados em água destilada e seccionados longitudinalmente na direção vestíbulo-lingual. As margens oclusais e cervicais dos espécimes foram avaliadas por escores, de acordo com a penetração do corante. Não foi observada infiltração significante nas margens oclusais, porém, nas margens cervicais, a infiltração apresentou-se significativamente reduzida quando o cimento de ionômero de vidro foi utilizado sob a resina composta. Também não foi observada a penetração do corante além do cimento de ionômero de vidro, sugerindo que a utilização deste material, abaixo da resina composta, pode significativamente diminuir a infiltração nas margens cervicais em restaurações de classe $\mathrm{V}$. Os autores concluíram que a redução na microinfiltração, principalmente nas margens cervicais, resultou da utilização da base de ionômero de vidro, uma vez que sua adesão à dentina minimiza a infiltração. Além disso, os efeitos da contração de polimerização e expansão térmica da resina composta são reduzidos, devido à menor quantidade de resina presente na cavidade.

Em 1990, TJAN; $\boldsymbol{D} \boldsymbol{U} \boldsymbol{N} \boldsymbol{N}^{144}$ avaliaram e compararam a microinfiltração nas margens cervicais de restaurações classe $\mathrm{V}$ de resina composta, forradas com os cimentos de ionômero de vidro fotoativado ou convencional. Oitenta cavidades foram preparadas nas faces mesial e distal de 40 molares humanos extraídos, com margens localizadas em esmalte e dentina. Os dentes foram aleatoriamente divididos em 4 grupos com 20 dentes cada. Grupo 1: ácido poliacrílico a $10 \%$ para condicionamento da superfície dentinária $+0,5 \mathrm{~mm}$ de Ketac Bond (ESPE)/ Visiomolar (ESPE) (controle); grupo 2: XR Ionomer/ Herculite (Kerr); grupo 3: ácido poliacrílico a 10\% + 0.5mm de XR Ionomer/ Herculite; grupo 4: Vitrabond/ P50 (3M). Posteriormente, os dentes foram termociclados em $0,5 \%$ de solução de fucsina básica, nas temperaturas de $4^{\circ} \mathrm{C}$ e $55^{\circ} \mathrm{C}$ com banhos de imersão de 1 minuto, perfazendo um total de 300 ciclos. A análise estatística não indicou diferença entre os grupos 2 e 4, os quais utilizaram bases do cimento de ionômero de vidro fotoativado, além de mostrar significante menor infiltração que o grupo controle. Assim, verificourse que ambos os cimentos de ionômero de vidro fotoativados mostraram-se mais eficientes em minimizar a infiltração, quando comparados ao convencional, no entanto, não foram encontradas diferenças significantes entre os dois materiais fotoativados utilizados. Os autores concluíram que a utilização de uma 
base de cimento de ionômero de vidro fotoativado reduz a infiltração marginal em cavidades classe $\mathrm{V}$ restauradas com resina composta, principalmente nas margens localizadas em dentina. Atribuíram este resultado a uma adesão forte e imediata do cimento de ionômero de vidro modificado por resina à dentina, a qual é capaz de resistir às forças geradas pela contração de polimerização da resina composta.

No mesmo ano, KEMP-SCHOLTE; DAVIDSON ${ }^{67}$ testaram a capacidade de selamento marginal de alguns sistemas adesivos e a combinação destes com diferentes materiais de base, os quais foram avaliados quanto à sua flexibilidade, como um mecanismo de compensar as tensões de contração das resinas compostas. Preparos de classe V cilíndricos foram realizados nas faces vestibulares e linguais de 96 dentes bovinos, com margens localizadas em esmalte e dentina. Os dentes foram divididos em 12 grupos de 8 e restaurados mediante diferentes combinações entre os materiais: 1- Scotchbond $1+$ Silux; 2- Scotchbond $1+$ Silux (dois incrementos); 3- Scotchbond $1+$ Silux + selamento das margens com sistema adesivo; 4 Scotchbond $2+$ Silux; 5- Scotchbond $2+$ camada intermediária (Silux Enamel Bond Resin) + Silux; 6- ionômero de vidro químico (Fuji lining cement) + Scotchbond $1+$ Silux; 7- ionômero de vidro químico (Fuji lining cement) + Scotchbond $2+$ Silux ; 8 ionômero de vidro químico (GI lining cement) + Scotchbond $1+$ Silux; 9 - Scotchbond $2+$ ionômero de vidro fotoativado (Vitrabond) + Silux; 10- Scotchbond $2+$ ionômero de vidro fotoativado (Ioline) + Silux; 11- Scotchbond 2 + camada grossa de ionômero de vidro fotoativado (Iocomp) recobrindo toda a dentina cavitária perdida + Silux; 12- Tenure Bond + camada fina do ionômero de vidro fotoativado (Zionomer Paste), cobrindo toda a superfície dentinária exposta + Silux. Todos os materiais foram manipulados de acordo com as instruções dos fabricantes, sendo que, nos grupos acima descritos, a resina composta foi inserida em incremento único, com exceção do grupo 2, no qual o material foi inserido de forma incremental. Metade dos espécimes de cada grupo recebeu 600 ciclos de termociclagem por 2 minutos a $5^{\circ} \mathrm{C} \mathrm{e} 60^{\circ} \mathrm{C}$. Posteriormente, os espécimes foram seccionados e réplicas foram feitas para a análise da integridade marginal no microscópio eletrônico de varredura. Os resultados mostraram que a termociclagem não apresentou influência significante na adaptação marginal. As tensões provenientes da contração de polimerização também foram avaliadas e observou-se um alívio de 20-50\% das mesmas, devido à presença de um material flexível intermediário. Pôde-se verificar que, com a aplicação de uma camada intermediária de uma resina fluida ou de um cimento de ionômero de vidro fotopolimerizável entre o agente 
de união e a resina composta, a adaptação marginal foi completa e perfeita (grupos 5, 9, 10 e 12). Concluiu-se que a utilização de uma camada intermediária pode compensar, em parte, as tensões da contração de polimerização que poderiam exceder a resistência adesiva, preservando a integridade marginal em restaurações de classe V.

Trabalhos laboratoriais são freqüentemente realizados para avaliar o desempenho dos materiais restauradores e seu comportamento clínico. Através de uma revisão de literatura, $\boldsymbol{R E T I E F ^ { 1 0 9 }}$, em 1991, analisou os diversos fatores a serem considerados quando da realização dos testes de adesão. Devido à dificuldade na obtenção de dentes humanos extraídos, o autor comentou, de acordo com a literatura, sobre a possível substituição desses pelos dentes bovinos para estudos laboratoriais. Para a avaliação dos testes de microinfiltração, a ADA estipulou que, para materiais adesivos dentinários, as cavidades deveriam localizar-se exclusivamente em dentina; a resina deveria ser inserida pela técnica incremental durante os procedimentos restauradores e os dentes deveriam permanecer armazenados em água, por pelo menos 24 horas previamente à ciclagem térmica. Os tempos de imersão nos banhos quente e frio variam nos trabalhos, porém o autor recomendou não exceder 15s, uma vez que imersões mais prolongadas não seriam suportáveis intraoralmente. Assim, os testes laboratoriais de adesão podem ser avaliados através da resistência adesiva aos substratos, microinfiltração e dimensões da fenda marginal na interface adesiva. Devido à grande variabilidade nas metodologias utilizadas, não se pode comparar os resultados obtidos de diferentes estudos laboratoriais, porém são considerados parâmetros, apesar desses resultados não poderem ser extrapolados às situações clínicas.

A adesão à dentina dos cimentos de ionômero de vidro modificado por resina (Vitrabond) e convencional (3M), indicados para bases cavitárias, foi comparada por MITR $\boldsymbol{A}^{90}$, em 1991. Utilizaram-se dentes bovinos, nos quais foram aplicados um dos cimentos de ionômero de vidro (modificado por resina ou convencional), o sistema adesivo e a resina composta $(\mathrm{P} 30)$. Os espécimes foram termociclados e testados quanto à resistência adesiva ao cisalhamento. Os resultados mostraram que a resistência à dentina bovina, imediatamente e após $24 \mathrm{~h}$ de armazenamento em água destilada, foi de $7 \pm 2 \mathrm{MPa}$ e $12 \pm 3 \mathrm{MPa}$ para o Vitrabond e $2 \pm 1 \mathrm{MPa}$ e $4 \pm 2 \mathrm{MPa}$ para o convencional, respectivamente, mostrando diferenças estatisticamente significantes. Observou-se que a adesão imediata à dentina do ionômero de vidro modificado por resina foi significativamente maior, comparada ao 
ionômero de vidro convencional. Os autores associaram a alta adesão do Vitrabond às suas boas propriedades físicas, sugerindo seu alto potencial para a utilização sob restaurações de resina composta.

Em busca de uma melhor adaptação marginal da resina composta à estrutura dentária, através de um método que permitisse um maior escoamento do material durante sua

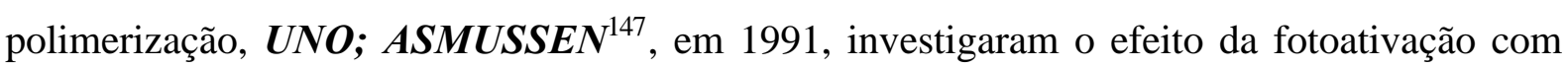
baixa intensidade de luz na adaptação marginal da resina composta em cavidades localizadas em dentina. Após o desgaste das superfícies vestibulares e linguais, cavidades cilíndricas foram confeccionadas na dentina de molares humanos extraídos. Em seguida, os preparos foram restaurados com resina composta (Silux Plus) em um único incremento e a superfície do material restaurador foi coberta com uma matriz, para que a fotoativação fosse realizada. Um transformador foi acoplado ao aparelho fotopolimerizador para permitir a redução da intensidade de luz ao nível desejado, reduzindo, assim, a velocidade de polimerização da resina composta. Os grupos foram divididos, considerando que 5 cavidades foram confeccionadas para cada condição a ser testada: 1 - 220V a 60s (baseline 1); 2- 220V a 30s (baseline 2); grupo A $-110 \mathrm{~V}$ por $5 \mathrm{~s} / 0 \mathrm{~V}$ por $25 \mathrm{~s} / 220 \mathrm{~V}$ por $30 \mathrm{~s}$; grupo B-110V por $10 \mathrm{~s} / 0 \mathrm{~V}$ por $20 \mathrm{~s} / 220 \mathrm{~V}$ por $30 \mathrm{~s}$; grupo $\mathrm{C}-110 \mathrm{~V}$ por $20 \mathrm{~s} / 0 \mathrm{~V}$ por $10 \mathrm{~s} / 220 \mathrm{~V}$ por $30 \mathrm{~s}$; grupo D- $110 \mathrm{~V}$ por $30 \mathrm{~s} / 220 \mathrm{~V}$ por $30 \mathrm{~s}$; grupo $\mathrm{E}-110 \mathrm{~V}$ por $60 \mathrm{~s}$. Observou-se que quando a resina composta foi irradiada por $30 \mathrm{~s}$ a $110 \mathrm{~V}$, seguida de 30 s a $220 \mathrm{~V}$, a adaptação marginal mostroutse significativamente melhor, com redução na largura e extensão das fendas marginais. Porém, um melhor grau de adaptação foi obtido no grupo E, o qual utilizou somente baixa intensidade de luz. Isto resultou em valores aceitáveis de resistência adesiva à dentina, mediante testes também realizados neste estudo. Os autores concluíram que uma pré-polimerização do material com baixa intensidade de luz, seguida da intensidade máxima, permite maior escoamento e diminuição da tensão de contração do mesmo, resultando em uma melhor adaptação marginal.

Para avaliar a microinfiltração, quando da utilização da técnica do sanduíche, MOUNT; PAPAGEORGIOU; MAKINSON ${ }^{93}$, em 1992, confeccionaram cavidades de classe $\mathrm{V}$ nas faces vestibulares e linguais de 24 molares. As margens cavitárias localizaram-se em esmalte e dentina, respectivamente. Os grupos controle foram restaurados somente com ionômero de vidro convencional (Chemfil II) ou modificado por resina (Fuji II). Os dentes 
que foram restaurados pela técnica do sanduíche receberam uma base de ionômero de vidro convencional Ketac Bond (toda margem dentinária) ou modificado por resina Vitrebond (0,5mm de espessura). Após a aplicação da base, fez-se o condicionamento do esmalte e do cimento de ionômero de vidro, aplicou-se o sistema adesivo (Visiobond) e as cavidades foram restauradas com resina composta (Superlux Solar) em dois incrementos. Os dentes foram armazenados em água por duas semanas e termociclados a $5^{\circ} \mathrm{C}$ e $55^{\circ} \mathrm{C}$ por 30 segundos em cada banho, perfazendo 500 ciclos. Posteriormente à imersão no corante, os dentes foram seccionados no sentido vestíbulo-lingual. Os resultados mostraram não existir infiltração em nenhuma das margens cavitárias dos espécimes dos grupos controle. Nos grupos onde o cimento convencional foi aplicado com pouca espessura, houve deslocamento do mesmo da dentina, enquanto o Vitrebond não se deslocou da dentina, mesmo em pequena espessura. Os autores concluíram que o sucesso obtido com o ionômero de vidro convencional utilizado como base deve-se a uma espessura adequada do material. Contudo, o modificado por resina pode ser inserido em uma fina camada. Desta forma, a pequena infiltração marginal observada na técnica do sanduíche referiu-se à contração de polimerização da resina composta.

TAYLOR; LYNCH ${ }^{142}$, em 1992, em uma revisão de literatura sobre as metodologias de algumas técnicas utilizadas para avaliar a microinfiltração, analisaram o emprego de ar pressurizado, culturas de bactérias, radioisótopos, microscopia eletrônica de varredura, estudos eletroquímicos, análise de ativação de nêutrons, ciclagem térmica e mecânica, traçadores químicos e penetração de corantes na interface dente/restauração. Os autores relataram que tais métodos são capazes de demonstrar a microinfiltração, porém verificaram que o uso de corantes para avaliar a microinfiltração constitui-se uma das técnicas mais utilizadas. Este método, associado a secções do dente, permite analisar toda a extensão da interface entre o material restaurador e o dente, além de demonstrar a infiltração em cores contrastantes com as estruturas dentárias e material restaurador, sem a necessidade de reações químicas ou exposições a radiações maléficas.

No mesmo ano, $\boldsymbol{S I D H U}^{128}$ verificou a infiltração marginal na interface adesiva de cavidades classe $\mathrm{V}$ em forma de cunha, utilizando cimentos de ionômero de vidro como materiais restauradores. Os preparos foram realizados na junção amelo-cementária das faces vestibulares e linguais de 60 dentes, com margens em esmalte e dentina ou cemento. As cavidades foram divididas em três grupos $(n=40)$ e restauradas com ionômero de vidro 
convencional (Fuji II-controle) ou com os fotoativados (XR-Ionomer e Fuji Lining LC). Metade dos espécimes de cada grupo foram submetidos a 500 ciclos de ciclagem térmica a $5^{\circ} \mathrm{C}$ e $55^{\circ} \mathrm{C}$ por 30 segundos. Posteriormente, foram imersos no corante por 24 horas e seccionados longitudinalmente para a análise da infiltração. Os resultados revelaram que a ciclagem térmica não afetou significativamente o selamento dos três materiais testados. Apesar da efetividade de ambos os tipos de cimentos ionoméricos, diferenças significantes foram observadas entre os grupos, com menor infiltração do corante na interface dentina ionômero de vidro híbrido. Contudo, não foram observadas diferenças significantes entre os dois cimentos híbridos testados, concluindo que ambos apresentam efetiva adesão à dentina em cavidades de classe $\mathrm{V}$.

A utilização de uma base de cimento de ionômero de vidro tem sido sugerida para a redução da microinfiltração, particularmente nas margens gengivais de restaurações classe V. Desta forma, PUCKETT et al. ${ }^{106}$, em 1992, compararam a infiltração marginal de três resinas compostas híbridas, inseridas sobre uma base de cimento de ionômero de vidro, utilizando técnicas de inserção única e incremental. Sessenta incisivos bovinos foram divididos em 6 grupos experimentais, com 10 dentes cada. Cavidades de classe V foram confeccionadas e restauradas com as referidas combinações de sistema adesivo/ resina composta: Bondlite/ Herculite XR; Scotchbond 2/ P50; Pertac Bond/ Pertac Hybrid. Todos os dentes receberam uma base de 0,5mm de cimento de ionômero de vidro Ketac Bond (ESPE), considerando que a dentina não foi condicionada previamente com ácido poliacrílico e não foi realizado o condicionamento ácido sobre este material. Após a realização das restaurações, através das técnicas única e incremental (três incrementos), os espécimes receberam o acabamento e foram armazenados a $37^{\circ} \mathrm{C}$ em água destilada por 24 horas. Em seguida, realizaram-se 100 ciclos em temperaturas de $4^{\circ} \mathrm{C}$ e $58^{\circ} \mathrm{C}$, com banhos de imersão de 1 minuto. Após a imersão em uma solução de radioisótopo $\mathrm{Ca}^{45}$ por 2 horas, os espécimes foram seccionados para a avaliação da microinfiltração através de escores. Quando da utilização de diferentes técnicas de inserção da resina composta, observaram-se diferenças significantes somente para a resina composta P50, na qual a técnica incremental melhorou significativamente a microinfiltração. Verificou-se que a resina composta Pertac Hybrid exibiu mais infiltração, quando comparada às outras duas, independentemente da técnica de inserção utilizada. Os autores comentaram que este resultado pode ser devido à expansão térmica apresentada por esta resina composta, sugerindo ser o maior fator que contribuiu para a microinfiltração. 
DOUGLAS; FUNDINGSLAND ${ }^{42}$ avaliaram, em 1992, as diferenças entre três materiais utilizados como forramento ou base sob restauração de resina composta, através do teste de microinfiltração. Terceiros molares foram utilizados para a confecção de 30 preparos de classe V, cujas margens localizaram-se em esmalte e dentina, respectivamente. As cavidades foram divididas em 3 grupos, com 10 dentes cada, e diferentes materiais de base foram aplicados nas paredes axial e gengival: grupo 1- TimeLine (fotopolimerizável), grupo 2- ionômero de vidro convencional (Ketac Bond), grupo 3- ionômero de vidro modificado por resina (Vitrebond). Em seguida, o sistema adesivo foi aplicado e a restauração realizada com resina composta (P50) em um único incremento. Posteriormente, os dentes foram termociclados em $5^{\circ} \mathrm{C}$ e $55^{\circ} \mathrm{C}$ por 30 segundos em cada banho, totalizando 500 ciclos e, em seguida, imersos em solução de nitrato de prata. Após o seccionamento dos espécimes, os resultados não revelaram infiltração nas margens em esmalte, porém todas as margens dentinárias apresentaram certo grau de penetração do corante. $\mathrm{O}$ grupo 1 apresentou maior infiltração comparado aos grupos 2 e 3, contudo não houve diferença significante entre esses últimos. Os autores concluíram que os cimentos de ionômero de vidro Ketac Bond e Vitrebond, utilizados como bases, são os de escolha para margens susceptíveis à cárie, uma vez que apresentam efeito cariostático e são capazes de minimizar a microinfiltração.

O mecanismo de adesão dos cimentos de ionômero de vidro convencional (Glass Ionomer Liner) e modificado por resina (Vitrebond) à dentina bovina foi investigado por $\boldsymbol{L I N}$; McINTYRE; DAVIDSO ${ }^{74}$, em 1992. Neste estudo foram realizados testes de resistência adesiva, análise da morfologia de superfície através do M.E.V. e confocal, além de medidas das trocas químicas nas áreas adesivas, por espectroscopia fotoelétrica de raios- $\mathrm{X}$ e de massa secundária. Os resultados revelaram que os maiores valores de resistência adesiva à dentina foram obtidos com o Vitrebond, imediatamente após a fotoativação e após 24 horas. Através da microscopia de varredura e confocal, observou-se evidente retenção mecânica do cimento ionomérico nos túbulos dentinários, mostrando-se esta mais efetiva com o Vitrebond. Pela espectroscopia de massa secundária foi possível verificar o processo de trocas iônicas entre os cimentos e a superfície dentinária. A espectroscopia fotoelétrica de raios- $\mathrm{X}$ revelou que as características de adesão foram significativamente afetadas pela fotopolimerização e pela estrutura química do polímero. 
WENDT; MCINNES; DICKINSON ${ }^{153}$, em 1992, avaliaram o efeito da ciclagem térmica na microinfiltração de restaurações de resina composta. Cavidades MOD foram confeccionadas em 50 molares humanos, com uma das margens cervicais localizada em cemento e a outra em esmalte. Os dentes foram restaurados com resina composta e divididos em 5 grupos: A- sem termociclagem e imersos em fucsina básica por 24h, B- sem termociclagem e imersos em fucsina por $4 \mathrm{~h}$; C- termociclagem $\left(250\right.$ ciclos a $5^{\circ} \mathrm{C}$ e $55^{\circ} \mathrm{C}$ por $15 \mathrm{~s})$ e imersos na fucsina por $24 \mathrm{~h}$; D- termociclagem e imersos no corante por $4 \mathrm{~h}$. Os resultados mostraram não existir aumento significante da microinfiltração nas restaurações que foram submetidas à termociclagem, quando comparadas as não termocicladas.

Considerando que não existe um método padronizado para avaliar a adaptação dos materiais restauradores às paredes cavitárias, TAYLOR; LYNCH ${ }^{143}$, em uma revisão de literatura realizada em 1993, abordaram diversos fatores que exercem efeito na adaptação marginal das restaurações. Assim, algumas características devem ser analisadas, tais como: tamanho e formato cavitário, localização das margens da cavidade, técnica de inserção do material restaurador, escolha do material, método de fotoativação, presença de forramento ou base, acabamento e polimento. Comentaram que as cavidades devem ser o mais idênticas possíveis para eliminar variações, pois o comportamento do material é influenciado pelo seu volume e, no caso das resinas compostas, deve ser considerado que quanto maior o volume do material, maior a contração que ocorre durante a polimerização. O formato cavitário também exerce influência na adaptação dos materiais, uma vez que os maiores valores de tensão, provenientes da contração de polimerização, são esperados em cavidades de classe I e V por apresentarem altos fatores de configuração cavitária. Conseqüentemente, essas tensões causam efeitos em maior magnitude nas margens dentinárias, locais onde a resistência adesiva é menor, quando comparada à obtida no esmalte. Também, a inserção do material restaurador em incrementos minimiza os efeitos da contração e, conseqüentemente, melhora a adaptação na interface dente-restauração. Comentaram ainda que os materiais restauradores apresentam diferentes propriedades, assim como diferentes capacidades para aderirem-se à dentina, o que influencia na obtenção de um adequado vedamento marginal. Este também pode ser afetado pela presença de algum material utilizado como forramento ou base cavitária, pois se o material empregado apresentar alta resistência adesiva à dentina, mas pobre afinidade com o material restaurador, uma fenda poderá se formar entre a base e a restauração. Desta forma, duas situações podem ser encontradas: a adesão base-restauração apresentar-se superior à 
adesão base-dentina e vice-versa. Diferentes técnicas de acabamento e polimento utilizadas constituem-se um importante fator a ser analisado, pois os diversos métodos que podem ser empregados relacionam-se à capacidade de resistência à infiltração dos materiais restauradores. Assim, os autores ressaltaram que a adaptação marginal pode ser avaliada tanto in vitro quanto in vivo por uma variedade de metodologias existentes, porém a padronização torna-se importante para a análise correta dos resultados.

Em 1993, com o intuito de aproveitar as propriedades favoráveis do cimento de ionômero de vidro e da resina composta, ARAÚUJO; MELLO; MENDES $\boldsymbol{S}^{8}$ avaliaram a infiltração marginal em restaurações realizadas com resina composta, com cimento de ionômero de vidro e com a associação desses dois materiais. Cavidades de classe V foram preparadas em 60 dentes humanos no limite amelo-cementário e foram divididas em seis grupos, de acordo com os materiais utilizados: 1- Ionômero de vidro XR Ionomer + XR Bond + Herculite (Kerr); 2- ionômero de vidro Bondex + AMRD + Adaptic P (Johnson \& Johnson); 3- Prisma Bond III + APH (Dentsply); 4- XR Bond + Herculite (Kerr); 5- ionômero de vidro experimental restaurador (Johnson \& Johnson); 6- ionômero de vidro restaurador Chelon Fil (ESPE). Terminadas as restaurações, os dentes foram cobertos com três camadas de esmalte de unha e a fluoresceína a $2 \%$ foi empregada durante a ciclagem térmica. A seguir, os dentes foram seccionados no sentido vestíbulo-lingual e fixados em lâminas de vidro para leitura em lupa estereoscópica. Os grupos 1, 2 e 5 não apresentaram infiltração marginal (0\%). Os grupos 3 e 4 revelaram menor porcentagem de dentes com infiltração marginal (20\% e 30\%) quando comparados ao grupo 6, o qual apresentou os maiores valores de infiltração (50\%). Apesar dos melhores resultados obtidos com a associação ionômero de vidro/ resina composta, os autores salientaram que os estudos realizados in vitro não reproduzem exatamente as condições presentes na boca, devendo-se, portanto, ser feita com cuidado a extrapolação dos resultados para as condições in vivo.

No ano de 1993, MARTIN; O'ROURKE ${ }^{80}$ examinaram, in vitro, quatro diferentes métodos de inserção da resina composta em cavidades de classe $\mathrm{V}$, quando inseridas sobre uma base de ionômero de vidro. Trinta e seis pré-molares receberam preparos nas faces vestibulares e linguais, com margens acima e abaixo da junção amelo-cementária. Em todas as cavidades uma base de ionômero de vidro (Vitrabond/3M) foi colocada e, a seguir, o esmalte foi condicionado, porém o cimento de ionômero de vidro e a dentina não receberam 
este procedimento. Aplicourse o adesivo Scotchbond 2 e os preparos foram restaurados, utilizando-se quatro técnicas de inserção: incremento único, inserção em dois incrementos verticais sobrepostos; inserção em dois incrementos verticais (o $1^{\circ}$ adaptado nas paredes gengival e axial e o $2^{\circ}$ cobrindo o $1^{\circ}$ e alcançando a parede oclusal); inserção em dois incrementos verticais (o $1^{0}$ contra a parede axial e margem oclusal e o $2^{\mathrm{o}}$ cobrindo o $1^{\mathrm{o}}$ e alcançando a parede gengival). Posteriormente, os dentes foram termociclados em $5^{\circ} \mathrm{C}$ e $55^{\circ} \mathrm{C}$ por um minuto, completando 500 ciclos. Os espécimes foram imersos em fucsina básica por 24 horas, incluídos em resina epóxica e seccionados para análise da microinfiltração. Nenhuma das técnicas de inserção utilizadas vedou completamente as margens oclusais ou gengivais, contudo, para todas as técnicas, as margens em esmalte mostraram menor infiltração do corante. O melhor vedamento dentinário foi alcançado com a técnica incremental, onde a porção gengival foi inserida primeiramente. $\mathrm{Na}$ maioria dos casos onde foi observada infiltração na margem dentinária, esta não ultrapassou a base utilizada, sugerindo que a alta aderência inicial dos cimentos de ionômero de vidro fotopolimerizáveis à dentina preveniu uma maior penetração do corante. Também, os autores relataram que o cimento de ionômero de vidro modificado por resina é suficiente para superar as tensões da contração de polimerização que tendem a romper o selamento nas margens cervicais.

MANGUM et $\boldsymbol{a l}^{78}{ }^{78}$, em 1994, compararam a extensão de microinfiltração, quando da utilização da técnica de inserção incremental ou única da resina composta, em preparos de classe V e cervicais de erosão/ abrasão. Trinta molares humanos receberam na face vestibular preparos de classe V (grupo 1) e trinta, simulando preparos cervicais de erosão/ brasão (grupo 2), com margens localizadas abaixo da junção amelo-cementária. Metade das cavidades de cada grupo foi restaurada com um único incremento de resina composta e utilização de uma matriz de compressão e, a outra metade, foi restaurada pela técnica incremental (três incrementos). As restaurações foram submetidas a 50 ciclos de termociclagem, em temperaturas de $35^{\circ} \mathrm{C}(20 \mathrm{~s}), 5^{\circ} \mathrm{C}(5 \mathrm{~s}) 35^{\circ} \mathrm{C}(20 \mathrm{~s})$ e $50^{\circ} \mathrm{C}(5 \mathrm{~s})$. Procedeu-se, a seguir, a imersão dos dentes em nitrato de prata e seccionaram-se os mesmos longitudinalmente para a avaliação em um microscópio com aumento de 25 vezes. A utilização da técnica de inserção única, juntamente com a matriz de compressão, reduziu a infiltração marginal nas margens cervicais, tanto nos preparos de classe $\mathrm{V}$ quanto nos de erosão/ abrasão. Os autores comentaram que um único incremento de resina composta, inserido sob pressão, reduz a contração de polimerização do material durante a fotoativação, 
minimizando, conseqüentemente, a microinfiltração. Concluíram que a menor penetração do corante quando comparado aos grupos restaurados de forma incremental, mostra facilidade, menor tempo de trabalho e redução da microinfiltração nas margens cervicais.

$\boldsymbol{R E T I E F ^ { 1 0 }}{ }^{10}$ em 1994, relatou que todas as resinas compostas sofrem contração de polimerização, resultando em forças de tensão na interface dente-restauração. Citou que as propriedades da resina composta, a contração de polimerização, os diferentes coeficientes de expansão térmica entre o dente e a restauração e a absorção de água determinam a dimensão da fenda e da microinfiltração nas restaurações de resina composta. $\mathrm{O}$ tamanho da cavidade também exerce significante influência na dimensão da fenda marginal. $\mathrm{O}$ autor afirmou que nenhum sistema adesivo é capaz de eliminar completamente a microinfiltração e que a tensão mastigatória contribui para o aumento da mesma. Entretanto, a infiltração marginal pode ser minimizada com a inserção da resina composta pela técnica incremental, bem como com o prolongamento para os procedimentos de acabamento e polimento, o que favorece a expansão higroscópica, permitindo uma melhor adaptação marginal.

Em 1994, RUEGGEBERG; CAUGHMAN; CURTIS ${ }^{114}$ propuseram-se a estudar o impacto de várias intensidades de luz e a duração do tempo de exposição sobre a polimerização da resina composta em diferentes profundidades (superfície, $1 \mathrm{~mm}, 2 \mathrm{~mm}$, $3 \mathrm{~mm}$ ). Os tempos de exposição foram de 20, 40, 60 e 80 s e a variação de luz foi obtida através da utilização de filtros, atingindo-se $587 \mathrm{~mW} / \mathrm{cm}^{2}, 400 \mathrm{~mW} / \mathrm{cm}^{2}$ e $233 \mathrm{~mW} / \mathrm{cm}^{2}$. A intensidade máxima foi de $800 \mathrm{~mW} / \mathrm{cm}^{2}$. Foram utilizadas duas resinas compostas (P50 e Silux Plus) em dois matizes (universal e cinza). Os resultados indicaram que, na superfície, a polimerização não foi grandemente afetada nem pela duração, nem pela intensidade de luz. Em profundidades maiores que $2 \mathrm{~mm}$, ocorreu inadequada polimerização do material. Observaram que a polimerização é muito susceptível às mudanças na intensidade de luz e no tempo de exposição. De acordo com os autores, um tempo de exposição de 60s e uma intens idade mínima de $400 \mathrm{~mW} / \mathrm{cm}^{2}$ de luz são recomendados para a polimerização da resina composta, não devendo ser utilizadas intensidades inferiores a $233 \mathrm{~mW} / \mathrm{cm}^{2}$. A espessura das camadas de resina composta não deve exceder $2 \mathrm{~mm}$, sendo $1 \mathrm{~mm}$ o ideal para uma adequada polimerização do material. 
A microinfiltração de três sistemas adesivos foi avaliada por REEVES $\boldsymbol{e t} \boldsymbol{a l}{ }^{108}$, em 1995, para determinar se os substratos bovinos são comparáveis aos humanos nos estudos de infiltração marginal. Foram realizadas cavidades de classe V em 30 dentes humanos e 30 bovinos, com margens localizadas abaixo e acima da junção amelo-cementária. As restaurações foram realizadas com os sistemas adesivos Scotchbond Multi Purpose, Prisma Universal Bond 3 e o All Bond 2, juntamente com a resina composta APH (incremento único). Após restaurados, os dentes foram armazenados em água por 3 dias, termociclados e mantidos em água por mais quatro dias a $37^{\circ} \mathrm{C}$. Posteriormente, foram colocados em isótopo de ${ }^{45} \mathrm{Ca}$ por 2 horas, seccionados e a infiltração marginal avaliada. Os resultados não revelaram diferença significante entre os sistemas adesivos no substrato humano, porém maior infiltração foi demonstrada na margem gengival utilizando-se o Scotchbond MP no dente bovino. Comparando-se os materiais, não foram observadas diferenças estatisticamente significantes nos índices de infiltração marginal entre os substratos humano e bovino. Pode-se observar que nenhum dos sistemas adesivos utilizados foi totalmente capaz de resistir às forças exercidas durante a polimerização e/ ou termociclagem, especialmente na margem gengival. Segundo os autores, os resultados deste estudo sugerem que os dentes bovinos podem substituir os humanos em testes de microinfiltração realizados in vitro.

Em 1995, ROSSOMANDO; WENDT JUNIOR ${ }^{112}$ avaliaram a infiltração marginal de alguns materiais restauradores, utilizando diferentes tempos de imersão dos espécimes durante a ciclagem térmica. Os autores propuseram-se a testar materiais que oferecessem diferentes condutibilidades térmicas, como o amálgama e a resina composta. Cavidades de classe $\mathrm{V}$ foram preparadas em 90 terceiros molares extraídos, com margens aquém e além da junção amelo-cementária, e três técnicas restauradoras foram avaliadas: apenas resina composta, adesivo e resina e amálgama com adesivo. Após restaurados os 30 dentes de cada grupo, os mesmos foram subdivididos em 3 grupos de 10 espécimes, para serem ou não submetidos à ciclagem térmica. Os grupos experimentais foram submetidos a 5.000 ciclos de termociclagem, em temperaturas de $5^{\circ} \mathrm{C}$ e $55^{\circ} \mathrm{C}$, com diferentes durações nos banhos: $10 \mathrm{~s}$ e 60s de imersão em fucsina básica. O grupo controle foi apenas imerso em solução de fucsina básica, em um tempo correspondente à imersão dos grupos experimentais. Quando os espécimes foram submetidos a ciclos com banhos de 10s, duração mais compatível clinicamente, não se observou aumento da microinfiltração nas restaurações de resina composta. Contudo, observaram que o grau de infiltração para as três técnicas restauradoras 
foi maior para os grupos submetidos a um tempo maior de imersão em cada banho (60s). Quando o menor tempo de estresse térmico foi utilizado (10s), não ocorreu diferença estatística quando comparado aos grupos controle. Os autores atribuíram tais resultados à baixa condutividade térmica das resinas compostas e afirmaram que o potencial de infiltração é aumentado com um desafio térmico mais prolongado. Desta forma, a maior duração do estresse térmico é capaz de anular as propriedades de isolamento térmico do material.

$\boldsymbol{A R} \boldsymbol{A} \boldsymbol{U} \boldsymbol{U} \boldsymbol{O} \boldsymbol{O}$ et $\boldsymbol{a l} .^{9}$, em 1995, avaliaram a adaptação dos cimentos de ionômero de vidro convencional e fotopolimerizável à dentina e à resina composta, através do teste de infiltração marginal. Preparos de classe V foram realizados nas faces vestibulares e linguais de vinte molares humanos extraídos. Todas as superfícies dentinárias foram condicionadas com ácido poliacrílico a $25 \%$ e os dentes foram divididos em 2 grupos com 20 cavidades cada. Grupo 1: CIV fotopolimerizável (Vitrabond) + RC; grupo 2: CIV convencional (Ketac Bond) + RC. Em ambos os grupos, metade das cavidades foram condicionadas com ácido fosfórico apenas nas paredes de esmalte, enquanto a outra metade recebeu o condicionamento do esmalte e do cimento de ionômero de vidro. Posteriormente, todos os dentes foram termociclados no corante e seccionados para avaliação da infiltração marginal. Os autores verificaram que não houve infiltração entre a resina composta e o ionômero de vidro fotopolimerizável (Vitrabond-3M) quando este foi condicionado, enquanto que, no grupo não condicionado, a infiltração ocorreu em 60\% das amostras. Com a utilização do ionômero convencional (Ketac Bond) nas duas condições experimentais, com e sem condicionamento, a infiltração marginal ocorreu em cerca de $40 \%$ e $30 \%$ das amostras, respectivamente. A freqüência de infiltração marginal entre os cimentos de ionômero de vidro e a dentina foi menor com o Vitrabond. Concluíram que o cimento de ionômero fotopolimerizável demonstrou melhor interação com a resina composta quando condicionado com ácido, e também com a dentina, quando comparado com o convencional, pois a infiltração marginal neste último mostroutse sempre presente, independente do tratamento recebido.

Um estudo in vitro foi realizado por BRACKETT $\boldsymbol{e t} \boldsymbol{a l} .^{17}$, em 1995, para avaliar a infiltração marginal de um cimento de ionômero de vidro convencional e de dois modificados por resina, em cavidades de classe V. Os preparos cavitários foram localizados na junção amelo-cementária e confeccionados nas superfícies vestibulares e linguais de 15 incisivos bovinos, os quais foram restaurados com o ionômero de vidro convencional (Ketac Fil) ou 
com os modificados por resina (Photac-Fil e Fuji II LC), sendo que 10 restaurações foram realizadas para cada material. Após o armazenamento por uma semana, os dentes foram submetidos a 200 ciclos de termociclagem a $5^{\circ} \mathrm{C}$ e $55^{\circ} \mathrm{C}$, com banhos de um minuto em cada temperatura. Em seguida, foram imersos no corante por 4 horas e seccionados para a análise da infiltração. Os resultados não mostraram infiltração severa do corante em nenhum dos espécimes, nem diferença significante entre os materiais testados, concluindo que os cimentos de ionômero de vidro modificados por resina apresentaram adaptação marginal equivalente ao quimicamente ativado.

Procurando abordar os fatores importantes para a obtenção de uma adequada polimerização do material, CAUGHMAN; RUEGGEBERG; CURTIS ${ }^{24}$, em 1995, realizaram uma revisão de literatura com o intuito de estabelecer alguns parâmetros. Mediante os vários fatores que podem afetar a polimerização dos compósitos, os autores recomendaram a utilização de aparelhos fotopolimerizadores de qualidade e que os mesmos sejam avaliados periodicamente, para irradiar uma intensidade de luz adequada. Sugerem que a intensidade de luz deve ser aferida com a utilização de radiômetro e que a intensidade mínima aceitável está compreendida entre $280 \mathrm{~mW} / \mathrm{cm}^{2}$ e $300 \mathrm{~mW} / \mathrm{cm}^{2}$. Para isso, é importante que os profissionais permaneçam atentos aos sinais de degradação do bulbo, refletor e da fibra óptica do aparelho. Adicionalmente, a resina composta seria um fator a ser considerado, uma vez que partículas de carga entre 0,01 a 1 micron reduzem a penetração de luz devido à dispersão, assim como o emprego de matizes mais escuros, os quais afetam negativamente a transmissão de luz. Comentaram ainda que cada incremento de resina composta não deve ultrapassar $2 \mathrm{~mm}$ e que a distância entre a ponta ativa do aparelho e a superfície da resina pode ser de até $6 \mathrm{~mm}$, quando 60s de exposição forem utilizados.

A proposta de UNTERBRINK; MUESSNER ${ }^{148}$, em 1995, foi avaliar o efeito de diferentes intensidades de luz na formação de fendas marginais, no desenvolvimento do módulo e da resistência flexural e na profundidade de polimerização de dois sistemas restauradores. As cavidades foram confeccionadas na dentina vestibular de 48 incisivos bovinos, os quais foram divididos de acordo com os diferentes procedimentos restauradores e intensidades de luz a serem utilizados: 1- Syntac/ Tetric/ 250mW/ $\mathrm{cm}^{2}$; 2- Syntac/ Tetric/ $450 \mathrm{~mW} / \mathrm{cm}^{2}$; 3- Scotchbond MP/ Tetric/ $250 \mathrm{~mW} / \mathrm{cm}^{2}$; 4- Scotchbond MP/ Tetric/

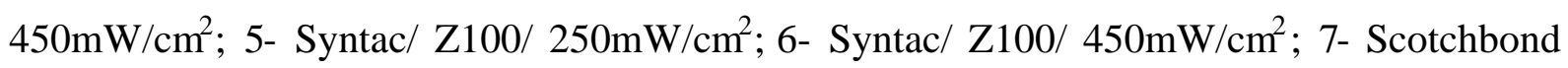


MP/ Z100/ 250mW/cm²; 8- Scotchbond MP/ Z100/ 450mW/ $\mathrm{cm}^{2}$. Em todos os grupos, a resina composta foi inserida em incremento único e btoativada por 40 segundos. A análise marginal mostrou que a resina composta Z100, quando utilizada tanto com o Scotchbond MP quanto com o Syntac, apresentou maior formação de fenda marginal quando fotoativada com alta intensidade de luz. A Tetric revelou melhor adaptação marginal comparada a Z100, quando utilizada com ambos os sistemas adesivos e com ambas as intensidades de luz. A resistência e o módulo flexural de ambas as resinas compostas foram inferiores quando fotoativadas com baixa intensidade de luz, após 30 minutos e 24 horas. Diferenças não foram encontradas na contração volumétrica ou profundidade de polimerização, relacionada ao método de fotoativação, para os dois materiais testados. Em um tempo de fotoativação de 40 segundos, os materiais foram igualmente polimerizados a uma profundidade de 4,5mm, independente da intensidade de luz utilizada. Concluiu-se que a utilização da alta intensidade de luz pode ocasionar inferior integridade marginal, devido a maior tensão de contração gerada, e que o desenvolvimento do módulo de elasticidade pode ser influenciado pela intensidade de luz.

Considerando que a intensidade de luz e o tempo de exposição constituem fatores importantes para um adequado grau de conversão da resina composta e, conseqüentemente, para a longevidade da restauração, FEILZER $\boldsymbol{e t} \boldsymbol{a l} .^{46}$, determinaram, em 1995, a influência da intensidade de luz na integridade da interface adesiva de restaurações de resina composta em cavidades de classe V. Este estudo também avaliou a influência da intensidade de luz na contração de polimerização e o efeito da utilização de uma camada intermediária elástica. Vinte e quatro pré-molares e caninos humanos receberam preparos classe V nas superfícies vestibulares e linguais, com margens cervicais localizadas abaixo da junção amelocementária. Os dentes foram divididos em 3 grupos: 1- sistema adesivo/ camada intermediária (Protect Liner)/ resina composta; 2- sistema adesivo/ resina composta; 3- sistema adesivo/ camada intermediária (Protect Liner) como material restaurador. Para cada grupo, metade dos espécimes foi fotoativada com $250 \mathrm{~mW} / \mathrm{cm}^{2}$ e metade com $650 \mathrm{~mW} / \mathrm{cm}^{2}$ de intensidade de luz. Após a ciclagem térmica $\left(400\right.$ ciclos a $\left.15^{\circ} \mathrm{C}-65^{\circ} \mathrm{C}\right)$, os espécimes foram seccionados no sentido vestíbulo-lingual e impressões foram feitas para a análise das réplicas no microscópio eletrônico de varredura. Os resultados mostraram continuidade aceitável na interface adesiva para ambas as intensidades utilizadas, contudo a utilização de baixa intensidade de luz mostrou-se significativamente melhor para a integridade marginal, quando comparada à alta 
intensidade. Segundo os autores, isto se deve à extensão do estado visco-elástico e à conseqüente redução do desenvolvimento das tensões de contração. Diferenças estatísticas não foram encontradas entre os grupos, pois a presença da camada intermediária elástica entre a parede cavitária e a resina composta (grupo 1), ou a restauração realizada com este material (grupo 3), não influenciou na integridade marginal obtida. A contração de polimerização para as duas condições analisadas foi similar, sugerindo semelhante grau de conversão e propriedades dos materiais. Concluíram que a utilização de baixas intensidades de luz, ao contrário da alta intensidade, contribui para uma melhor integridade marginal em restaurações realizadas em cavidades de classe $\mathrm{V}$.

BURROW $\boldsymbol{e t}$ al. ${ }^{20}$, em 1996, investigaram a resistência adesiva de diferentes sistemas adesivos (All Bond 2, Super Bond D Liner Plus, Clearfil Liner Bond II e ProBond) à dentina bovina coronária e radicular. Adicionalmente, a estrutura da camada híbrida formada por cada um dos sistemas foi analisada. A superfície do esmalte dos dentes bovinos foi lixada até a exposição da dentina coronária e radicular. Uma área de adesão de $3 \mathrm{~mm}$ de diâmetro foi demarcada e os procedimentos de adesão foram realizados, segundo as instruções dos fabricantes dos sistemas adesivos; exceto para o Super Bond D-Liner Plus, onde o primer foi deixado no local por 60s previamente à secagem com ar. Posteriormente à fotoativação dos sistemas adesivos, uma fina camada de resina composta (Photo Clearfil Bright) foi aplicada e polimerizada. Os espécimes permaneceram armazenados em água deionizada por $24 \mathrm{~h}$. Os testes de resistência adesiva foram realizados, utilizando uma máquina de ensaios universal. Os espécimes foram avaliados ao MEV e mostraram diferenças na micromorfologia da superfície das fraturas das dentinas coronária e radicular para cada sistema adesivo. Os resultados revelaram baixa resistência adesiva à dentina coronária quando comparada à radicular com o sistema adesivo All Bond 2, enquanto o Liner Bond II mostrou o oposto. Os sistemas ProBond e Super-Bond D-Liner Plus não mostraram diferença significante entre dentina coronária e radicular. As camadas híbridas formadas com os sistemas adesivos All Bond 2, Liner Bond II e Super Bond D Liner Plus foram observadas e não revelaram diferença aparente entre os dois tipos de dentina avaliados. No caso do ProBond, a smear layer não foi removida e pareceu que o primer infiltrou, promovendo hibridização. As diferenças na resistência adesiva pareceram estar relacionadas às diferenças nos mecanismos de adesão de cada material, assim como a possíveis variações nos substratos dentinários 
coronário e radicular. Os autores concluíram que a adesão ao substrato dentinário bovino é possível, quando utilizado um adequado sistema adesivo para cada situação clínica específica.

Em 1996, SJÖDIN; UUSITALO; VAN DIJKE $\boldsymbol{N}^{134}$ avaliaram a microinfiltração dos cimentos de ionômero de vidro convencional (Chemfil II/Dentsply e Baseline/ Dentisply), modificados por resina (Fuji II LC/GC e Vitremer/3M), de um compômero (K71, produto experimental do Dyract) e de uma resina composta (Herculite XRV/Kerr), em cavidades classe V e classe II (sanduíche), com margens cervicais localizadas abaixo e acima da junção amelo-cementária. Cinqüenta dentes foram utilizados para os preparos de classe $\mathrm{V}$ nas faces vestibulares e linguais, os quais foram restaurados com os materiais acima citados. Outros cinqüenta dentes receberam preparos de classe II, sendo que quatro grupos foram restaurados utilizando-se uma base de Fuji II LC, K71, Vitremer ou Baseline + resina, e um último grupo foi restaurado somente com resina composta. Depois de restaurados, os dentes foram termociclados, colocados em azul de metileno a $5 \%$ por 24 horas e seccionados para avaliação, utilizando o critério de escores. Nas cavidades de classe V, a infiltração marginal foi mais severa na margem cervical do que na oclusal. O Baseline e Herculite XRV apresentaram maior infiltração; o compômero K71 e o Fuji II LC mostraram-se mais eficazes para minimizar a infiltração nas margens localizadas em dentina, comparados ao Vitremer e Chemfill. Nas restaurações tipo sanduíche, realizadas nas cavidades de classe II, o cimento de ionômero convencional demonstrou maior infiltração que os modificados por resina, porém as diferenças não foram significantes. Os resultados sugerem que a adesão inicial obtida, após a fotoativação do ionômero de vidro modificado por resina, é mais forte que a apresentada pelos convencionais. Verificourse que as diferentes técnicas restauradoras não foram capazes de resistir à microinfiltração nas margens localizadas em esmalte ou dentina, porém, as margens dentinárias exibiram maiores índices de infiltração, sendo que pesquisas clínicas ainda são necessárias para afirmar o comportamento clínico dos materiais.

DÉJOU; SINDRES; CAMPS ${ }^{39}$, em 1996, compararam métodos estatísticos empregados para avaliação in vitro da eficiência do selamento de restaurações adesivas, através do teste de microinfiltração. Cavidades de classe $\mathrm{V}$ foram preparadas em molares e pré-molares humanos e os dentes foram restaurados com 13 diferentes sistemas restauradores. Posteriormente, foram submetidos a 100 ciclos de temociclagem a $5^{\circ} \mathrm{C}$ e $55^{\circ} \mathrm{C}$ por 30 s, imersos na fucsina básica a $0,5 \%$ por 24 horas e seccionados para avaliação. Registraram-se 
cinco critérios de avaliação: média dos resultados de penetração do corante de cada dente fatiado (três fatias e seis interfaces), a mediana, a moda, penetração máxima do corante e a porcentagem de dentes em cada grupo sem infiltração. Os autores relataram que a avaliação da máxima penetração do corante para cada dente apresentou-se como o melhor critério. Contudo, os resultados destas metodologias de infiltração marginal são dependentes dos critérios de avaliação selecionados e dos materiais restauradores utilizados.

A influência da utilização da base de cimento de ionômero de vidro modificado por resina na infiltração marginal de restaurações de resina composta, em cavidades classe $\mathrm{V}$, foi avaliada por TRUSHKOWSKY; GWINNETT ${ }^{146}$, em 1996. As cavidades foram preparadas no terço cervical das faces vestibular e lingual de 35 dentes extraídos, os quais foram aleatoriamente divididos em sete grupos, com cinco dentes cada. Grupo 1 (controle): Scotchbond Multi-Purpose (SMP) / Z100 (técnica incremental); grupo 2- base com Fuji LC a 0.5mm de espessura + SMP + Z100; grupo 3- base com Fuji II LC (1,0mm) + SMP + Z100; grupo 4- base com Vitrebond $(0,5 \mathrm{~mm})+\mathrm{SMP}+\mathrm{Z100}$; grupo 5- base com Vitremer $(1,0 \mathrm{~mm})$ + SMP + Z100; grupo 6- Fuji II LC; grupo 7- Vitremer. Os dentes foram submetidos a 1.500 ciclos de termociclagem nas temperaturas de $5^{\circ} \mathrm{C}$ e $55^{\circ} \mathrm{C}$, com banhos de imersão de 30 segundos e, em seguida, imersos em solução de nitrato de prata. Após o seccionamento longitudinal pelo centro de cada restauração, a penetração do corante na interface adesiva foi analisada nas margens cervicais e oclusais, através de escores. Os resultados revelaram que todos os grupos demonstraram mínima ou ausência de infiltração tanto nas margens cervicais, quanto nas oclusais, não apresentando diferenças significantes na infiltração marginal entre eles. Porém, mínima infiltração foi observada na margem gengival quando o CIVMR foi utilizado sob as restaurações de resina composta, quando comparado ao grupo controle. Concluíram que a utilização do cimento de ionômero de vidro modificado por resina, sob restaurações de resina composta, não foi capaz de resistir à infiltração marginal em ambas as margens, apresentando-se indiferente em relação aos demais grupos.

No ano de 1996, ABOUSHALA; KUGEL; HURLE $\boldsymbol{Y}^{1}$ investigaram a capacidade de selamento do cimento de ionômero de vidro quando utilizado como base em restaurações classe II de resina composta. As cavidades foram confeccionadas em 30 dentes humanos posteriores, sendo os mesmos divididos em 3 grupos $(n=10)$ : a- resina composta; b- base de ionômero de vidro fotopolimerizável nas paredes pulpar e axial (somente em dentina) + resina 
composta; c- ionômero de vidro fotopolimerizável nas paredes pulpar e axial, estendido até a margem cavo-superficial + resina composta. Os espécimes foram termociclados, imersos em fucsina básica a $0,5 \%$ por 24 horas e seccionados para análise através de escores. Não foram observadas diferenças entre as restaurações de resina composta (a) e aquelas que receberam uma base de ionômero de vidro aplicado somente em dentina (b). Os resultados indicaram que a aplicação da base de ionômero de vidro sob a resina composta foi efetiva em reduzir a infiltração marginal quando a mesma foi estendida até a margem cavo-superficial (c). Os autores concluíram que a aplicação do cimento de ionômero de vidro até a margem cavosuperficial inibe a microinfiltração em restaurações de classe II, realizadas in vitro.

O selamento marginal de restaurações classe II de resina composta, de acordo com a localização das margens cervicais, foi verificado por SCHUCKAR; GEURTSEN ${ }^{124}$, em 1996. Cavidades MOD foram confeccionadas em 60 molares humanos extraídos, com as margens cervicais da caixa proximal localizadas $1 \mathrm{~mm}$ acima da junção amelo-cementária (1), 0,5mm acima (2), na junção (3a, b) e 0,5mm abaixo do limite amelo-cementário (4a, b). Todas as cavidades foram forradas com cimento de ionômero de vidro e restauradas com resina composta. Nos grupos $3 b$ e $4 b$, o sistema adesivo foi aplicado nas caixas proximais previamente à resina composta. Metade dos espécimes de cada grupo foram termociclados $\left(5^{\circ} \mathrm{C}\right.$ e $55^{\circ} \mathrm{C}, 2000$ ciclos) e os cinco dentes restantes permaneceram como controle. Os espécimes foram imersos no corante, seccionados e avaliados quanto à adaptação cervical. $\mathrm{O}$ melhor selamento das margens foi obtido no grupo 1, seguido pelo 4b, 2, 3b, 4a e 3a. Os resultados mostraram que a ciclagem térmica resultou em significante deterioração do vedamento marginal nos grupos 2, 4a e 4b. Os autores concluíram que a aplicação de um adesivo dentinário pode melhorar o selamento marginal proximal das resinas compostas, localizadas próximas à junção amelo-cementária. Adicionalmente, a adaptação marginal é significativamente dependente da localização das margens cavitárias.

CARVALHO et $\boldsymbol{a l}^{23}{ }^{23}$, em 1996, revisaram os fatores que propiciam à resina composta um maior alívio das tensões provenientes da contração de polimerização. Inicialmente, mostraram a importância do fator de configuração cavitária, afirmando que o relaxamento das tensões está em função da deformação elástica do material e do seu escoamento para superfícies livres. Destacaram que as cavidades tipo caixa possuem uma maior área de superfície aderida, o que limita o escoamento do material e, quanto menor esta capacidade, 
maior a tensão proveniente da contração de polimerização. Os autores descreveram que as resinas quimicamente ativadas apresentam uma reação de polimerização mais lenta, permitindo um maior tempo para alívio das tensões, comparada às resinas fotopolimerizáveis. Afirmaram que, quanto maior a concentração de matriz orgânica na composição de uma resina composta, maior será a tendência para a absorção de água, o que parcialmente compensa a contração de polimerização. Comentaram ainda sobre soluções para redução da competição existente entre resistência de união à dentina e as forças da contração de polimerização, enfatizando inicialmente sobre a necessidade do desenvolvimento de agentes adesivos dentinários capazes de efetuar uma imediata resistência de união, superior às forças de contração de polimerização. A colocação de um material, com baixo módulo de elasticidade entre a resina composta e a dentina, teria a finalidade de absorver a tensão proveniente da contração de polimerização ou, até mesmo, advinda da própria mastigação. Adicionalmente, sugerem a utilização da técnica de inserção incremental, a qual reduz o volume de resina que contrai durante a polimerização, assim como diminui o fator $\mathrm{C}$, uma vez que a porção de resina colocada possuirá grande quantidade de área livre para aliviar a tensão gerada pela contração de polimerização. Os autores concluíram que o sucesso clínico das restaurações de resina composta está no entendimento destes fatores, os quais podem reduzir as forças de contração de polimerização.

ARAÚJO; ARAÚJO; MENDES ${ }^{7}$, em 1996, propuseram-se a verificar, através de testes de infiltração marginal, se as diferentes intensidades de luz emitidas interferem no selamento marginal das restaurações de resina composta. Sessenta restaurações de classe V foram realizadas nas faces vestibulares de dentes posteriores extraídos, os quais foram divididos em 6 grupos. Foram restaurados com a resina composta Z100 e fotoativados com seis aparelhos fotopolimerizadores, que emitiram diferentes intensidades de luz: 1$50 \mathrm{~mW} / \mathrm{cm}^{2}$, 2- $180 \mathrm{~mW} / \mathrm{cm}^{2}, 3-450 \mathrm{~mW} / \mathrm{cm}^{2}, \quad 4-600 \mathrm{~mW} / \mathrm{cm}^{2}, \quad 5-600 \mathrm{~mW} / \mathrm{cm}^{2}$, 6$800 \mathrm{~mW} / \mathrm{cm}^{2}$. Os dentes foram submetidos à termociclagem no corante e, em seguida, foram seccionados para a avaliação através de escores. O grupo 1 apresentou a menor infiltração marginal gengival, enquanto que maior infiltração do corante foi observada no grupo 6. Os autores justificaram que a intensidade de luz utilizada no grupo 1 foi insuficiente e que a absorção de água pela resina composta pode ter aumentado, devido à polimerização incompleta do material. Com isso, a fenda ocasionada pela contração de polimerização teria sido fechada pela expansão da resina, proporcionando uma melhor adaptação marginal. Os 
maiores valores de infiltração verificados no grupo 6 foram atribuídos à alta intensidade de luz utilizada; afinal, o grau de polimerização pode ter sido muito grande, sugerindo aumento na contração de polimerização. Verificaram que aparelhos fotopolimerizadores com alta intensidade de luz promovem uma completa polimerização das resinas compostas, porém, induzem a maior contração de polimerização, com conseqüente infiltração marginal. Intensidades entre $180 \mathrm{~mW} / \mathrm{cm}^{2}$ a $600 \mathrm{~mW} / \mathrm{cm}^{2}$ mostraram-se mais adequadas para o selamento de restaurações de resina composta. Os autores concluíram que a intensidade de luz teve influência na infiltração marginal da parede cervical, sendo que os maiores níveis ocorreram com a intensidade de luz mais intensa.

Um método alternativo de polimerização é a exposição gradual da resina composta à fonte de luz, o que parece permitir o escoamento do material, resultando em uma melhor adaptação marginal. GORACCI; MORI; MARTINIS ${ }^{57}$, em 1996, compararam a adaptação da resina composta à dentina após a fotoativação do material de forma convencional e gradual. Cavidades de classe $\mathrm{V}$ foram confeccionadas em pré-molares humanos extraídos e restauradas com o sistema adesivo Scotchbond Multi-Purpose e a resina composta Z100 de forma incremental. No primeiro grupo (A), todas as camadas foram fotoativadas pela técnica convencional (40s a $250 \mathrm{~mW} / \mathrm{cm}^{2}$ ), enquanto que, no segundo grupo (B), foi utilizada a técnica de fotoativação lenta na primeira camada de resina. Para isso, um aparelho regulador foi adicionado ao convencional para permitir o aumento gradual da intensidade de luz emitida em uma faixa de 30 a $250 \mathrm{~mW} / \mathrm{cm}^{2}$ em 4 minutos. Posteriormente, réplicas de resina foram confeccionadas para serem observadas através do microscópio eletrônico de varredura. $\mathrm{O}$ grupo A não apresentou fendas na interface esmalte-resina, porém o exame da interface dentina-resina revelou a presença de fendas de aproximadamente $10 \mu \mathrm{m}$. Este resultado devese à contração proveniente da polimerização iniciada pela fotoativação convencional, que gerou tensão concentrada nas áreas de união mais frágeis. Em contraste, nos espécimes em que a primeira camada de resina foi polimerizada gradualmente (B), uma continuidade estrutural foi observada entre o material restaurador e a dentina; afinal, a tensão gerada pela contração não foi suficiente para romper as ligações adesivas entre material restaurador e estrutura dentária. Os autores concluíram que é possível melhorar a adaptação das resinas compostas à superfície dentinária através da redução na velocidade de polimerização, representando, desta forma, uma solução aos problemas de adesão em restaurações de resina composta. 
Através de uma revisão de literatura, DAVIDSON; FEILZEE ${ }^{36}$, em 1997, discutiram os problemas relacionados com a contração de polimerização dos materiais e a tensão gerada por essa contração. Relataram que a contração ocorre durante a polimerização das resinas compostas e dos cimentos de ionômero de vidro, porém, seus efeitos podem ser minimizados mediante a utilização de bases cavitárias e da modulação da fotoativação. Adicionalmente, existe uma relação direta entre fator $\mathrm{C}$ e desenvolvimento das tensões, ou seja, quanto maior esse fator, maior o desenvolvimento das tensões da contração. Comentaram que o emprego de uma base cavitária com um material de baixo módulo de elasticidade, como o cimento de ionômero de vidro, contribuiria para a distribuição mais homogênea dessas tensões. Também, a redução da intensidade de luz inicial proporcionaria uma lenta reação de polimerização do material, permitindo um melhor escoamento do mesmo e, conseqüentemente, uma melhor integridade marginal. Os autores concluíram que é importante o conhecimento dos problemas relacionados à contração de polimerização, com o intuito de buscar técnicas que minimizem os efeitos por ela gerados.

MEHL; HICKEL; KUNZELMANN ${ }^{88}$, em 1997, investigaram a influência de diferentes condições de fotoativação inicial, seguidas por uma fotoativação final com máxima intensidade de luz, sobre a formação de fendas marginais. Adicionalmente, avaliaram o efeito destas técnicas de fotoativação sobre as propriedades físicas (módulo flexural, resistência flexural e microdureza) de duas resinas compostas. Para avaliação da qualidade marginal, cavidades de classe $\mathrm{V}$ foram preparadas com margens acima e abaixo da junção amelocementária, em 32 molares humanos extraídos. As cavidades foram restauradas com a resina composta Tetric em um único incremento e dividiram-se os dentes em 4 grupos, onde diferentes intensidades de luz iniciais foram aplicadas. A intensidade máxima de luz (100\%) de $450 \mathrm{~mW} / \mathrm{cm}^{2}$ ( $0 \mathrm{~mm}$ de distância) foi utilizada para a fotoativação por 60s das restaurações do grupo 1, enquanto que os grupos 2, 3 e 4 foram fotoativados por 20s com intensidades iniciais correspondentes a 70, 50 e 37\%, seguidas por uma intensidade final máxima (100\%) por 40s. As intensidades de luz utilizadas variaram mediante o controle da distância entre a superfície do material e a fonte de luz. Os dentes foram termociclados $\left(500\right.$ ciclos a $5^{\circ} \mathrm{C}$ e $55^{\circ} \mathrm{C}$ por $30 \mathrm{~s}$ ) e réplicas foram preparadas para a avaliação das fendas marginais, através de microscopia eletrônica de varredura. Adicionalmente, os dentes foram imersos no corante e as restaurações seccionadas para a avaliação da infiltração. O estudo in vitro da análise marginal demonstrou que a fotoativação inicial com $56 \%$ e $70 \%$ de intensidade de luz por 20 s, seguida 
por $100 \%$ (intensidade máxima) por 40s, proporcionou integridade marginal significativamente melhor quando comparada com o uso de alta intensidade de luz somente. Os resultados também indicaram que uma fotoativação inicial com menor intensidade de luz não influenciou na microdureza e aumentou o módulo e a resistência flexural. Os autores concluíram que a fotoativação inicial com baixa intensidade de luz, seguida de uma intensidade máxima final, é considerado um método confiável para a obtenção de uma melhor integridade marginal, associada a melhores propriedades físicas do material.

A influência da intensidade de luz e a variação no tempo de irradiação na eficácia da polimerização de dois tipos de resina composta foram avaliadas por DAVIDSON-KABAN et $\boldsymbol{a l} \mathbf{l}^{38}$, em 1997. Verificou-se ainda o efeito da intensidade reduzida de luz na preservação da adaptação interna às paredes da cavidade. Neste estudo, foram utilizadas as resinas compostas de micropartículas (Silux Plus) e a híbrida (P50). Para a avaliação da adaptação interna, foram realizadas cavidades de classe $\mathrm{V}$ em dentes bovinos, localizadas em dentina, com dimensões de 1,5 $\mathrm{mm}$ de profundidade, 3,5 $\mathrm{mm}$ de largura e 2,5 $\mathrm{mm}$ de altura. Os materiais restauradores foram fotoativados com duas densidades de potência: $700 \mathrm{~mW} / \mathrm{cm}^{2}$ por $60 \mathrm{~s}$ e $10 \mathrm{~s}$ e a $175 \mathrm{~mW} / \mathrm{cm}^{2}$ por $60 \mathrm{~s}$. Após 24 horas de armazenamento, os procedimentos de acabamento e polimento foram realizados e os espécimes seccionados vestíbulo-lingualmente através da restauração. Obtiveram-se réplicas que foram analisadas em M.E.V. Pela análise dos resultados, observou-se que não houve diferença estatística na adaptação interna entre os dois tipos de resinas compostas utilizadas. Para a resina microparticulada, houve um número significativamente maior de defeitos visíveis quando se utilizou uma densidade de potência de $700 \mathrm{~mW} / \mathrm{cm}^{2}$, quando comparada a uma densidade de $175 \mathrm{~mW} / \mathrm{cm}^{2}$ em um tempo de irradiação de 60 segundos. Quando se alterou o tempo de exposição de 60s para 10s, houve uma diminuição significante no número de defeitos visíveis para a resina híbrida, mas não para a de micropartículas. Além disso, observou-se que, quando se reduziu a densidade de potência, houve um menor grau de conversão dos monômeros, mas, apesar disto, foi possível se obter boas propriedades mecânicas e uma boa adaptação às paredes da cavidade.

Revisando sobre os diferentes métodos para detecção da microinfiltração, $\boldsymbol{A L} \boldsymbol{A N I}$; $\boldsymbol{T O H}^{3}$, em 1997, relataram que o uso de corantes orgânicos é um método antigo e comum para detectar a infiltração marginal in vitro, além da sua facilidade de aquisição, baixo custo e por não ser tóxico. Os autores mostraram a variedade de resultados quanto à influência da 
termociclagem sobre a microinfiltração, relacionando também as temperaturas utilizadas e a duração dos banhos. Recomendaram que os testes de microinfiltração, realizados em restaurações adesivas, sejam feitos somente após 24 horas do armazenamento dos espécimes, para permitir que a sorpção de água aconteça. Os autores finalizaram, afirmando a inexistência de um método eficaz e ideal para avaliação da microinfiltração, contudo, a utilização de corantes, é considerado um dos mais práticos, confiáveis e aceitos.

FRIEDL et al ${ }^{51}$, em 1997, compararam a qualidade marginal de cavidades de classe II restauradas com resina composta ou associada ao cimento de ionômero de vidro (técnica sanduíche). Utilizaram-se 48 molares humanos, nos quais as cavidades foram confeccionadas e restauradas com os seguintes materiais: grupo 1- Scotchbond MP/ Z100 (3M); grupo 2 Probond/ Prisma TPH (Dentsply); grupo 3- Vitremer na parede gengival/ Scotchbond MP/ Z100 (3M); grupo 4 - Dyract/ Probond/ Prisma TPH (Dentsply). As margens foram avaliadas quanto à adaptação marginal, antes e após o tratamento termomecânico $\left(5.000\right.$ ciclos a $5^{\circ} \mathrm{C}$ e $55^{\circ} \mathrm{C}$ por 30 segundos; $72,5 \mathrm{~N}$ ), através de microscopia eletrônica de varredura e também quanto à microinfiltração, antes e após a termociclagem. Os dentes foram divididos em quatro grupos de doze, onde seis espécimes de cada grupo foram avaliados por M.E.V e os seis restantes, pelo método de penetração do corante. A carga termomecânica não apresentou influência significante na microinfiltração, mas mostrou significante influência na formação de fendas. Assim, o grupo 1 apresentou maiores fendas marginais nas margens cervicais antes e após a ciclagem termomecânica, em comparação aos outros grupos. Segundo os autores, este grupo foi mais susceptível à termociclagem, apresentando mais fendas marginais em dentina que a técnica do sanduíche (Vitremer + Z100). Porém, não houve diferença estatisticamente significante entre os grupos testados na interface dentina/ material restaurador quanto à microinfiltração. Os autores concluíram que a técnica sanduíche promove boa adaptação marginal, podendo ser uma alternativa para as restaurações com resina composta.

Para avaliar a possibilidade de substituição dos dentes humanos pelos bovinos e suínos, em testes laboratoriais de adesão, CORADAZZI et al.$^{30}$, em 1998, compararam a resistência ao cisalhamento de um sistema adesivo em esmalte e dentina de dentes humanos, bovinos e suínos, após 24 horas e 7 dias de estocagem em água. Foram utilizados 60 prémolares humanos, 60 incisivos bovinos e 30 molares suínos, os quais foram divididos de 
acordo com o tipo do dente, a superfície a ser testada e o período de observação. Após a planificação das superfícies com discos de lixa e a aplicação do sistema adesivo Prisma Universal Bond 3, um cilindro foi fixado sobre essas superfícies para limitar a área e a matriz foi preenchida com resina composta. Após os testes de resistência ao cisalhamento, os resultados revelaram que a resistência adesiva no esmalte humano não apresentou diferença significante em relação ao esmalte bovino, entretanto, ambos apresentaram diferenças em relação ao esmalte suíno. A resistência adesiva na dentina humana, bovina e suína não apresentou diferenças significantes entre si após 24 horas e 7 dias. Os autores concluíram que o esmalte e dentina bovinos são uma alternativa para o substrato humano em testes de adesão.

Em 1998, TOLIDIS; NOBECOURT; RANDALL ${ }^{145}$ examinaram a contração de polimerização volumétrica de cinco marcas comerciais de resinas compostas (Tetric Ceram, Prodigy, Z100 MP, Solitaire, Aeliteflo). Os materiais foram avaliados isoladamente (grupo A) e associados a uma base de cimento de ionômero de vidro modificado por resina - Vitrebond (grupo B). Vinte corpos de prova de cada grupo foram obtidos e a contração volumétrica foi medida através da subtração da espessura original pela espessura final. A espessura dos materiais avaliados foi de $2 \mathrm{~mm}$ para as resinas compostas e $0,5 \mathrm{~mm}$ para o ionômero de vidro. Os resultados demonstraram que as resinas compostas apresentaram uma contração de polimerização significativamente menor quando em contato com o CIVMR (Vitrebond), comparado ao grupo no qual a resina foi polimerizada isoladamente. A contração de polimerização das resinas compostas foi reduzida em torno de $41 \%$ na presença da base de ionômero de vidro. Os autores concluíram que a utilização de uma base de CIVMR reduz significativamente a contração de polimerização volumétrica das resinas compostas, uma vez que é capaz de absorver parte da tensão proveniente da contração de polimerização.

A resistência adesiva de cimentos de ionômero de vidro modificados por resina, no período de tempo de 1 minuto a 24 horas após a fotoativação, foi avaliada por MIYAZAKI et $\boldsymbol{a l} .^{91}$, em 1998. Utilizaram dentes bovinos, nos quais foram lixadas as superfícies vestibulares, a fim de expor a dentina para os testes de adesão. Delimitou-se uma área na dentina, através de fita adesiva com $4 \mathrm{~mm}$ de diâmetro. A superfície foi tratada com os condicionadores/primers, de acordo com as instruções dos fabricantes dos cimentos de ionômero de vidro Fuji II LC e Vitremer. Em seguida, com auxílio de moldes de vinil (4mm de diâmetro e $2 \mathrm{~mm}$ de altura), os materiais foram inseridos e adaptados à dentina previamente 
tratada. Os espécimes dos grupos controle foram restaurados com cimento de ionômero de vidro convencional (Fuji II) e com resina composta (Optibond/ Herculite XRV). As resistências adesivas foram testadas após 1, 5, 10, 30 e 60 minutos e após 2, 5 e 24 horas de armazenamento em água por $37^{\circ} \mathrm{C}$. Os resultados mostraram que a resistência adesiva à dentina de todos os materiais testados aumentou com um tempo de armazenamento prolongado, e que a proporção de aumento foi diferente entre os materiais. O primeiro aumento significante de resistência adesiva foi observado para o Fuji II LC e Optibond com 10 minutos, para o Fuji II com 20 minutos e para o Vitremer com 60 minutos. A resistência adesiva do CIVMR foi maior que a obtida com o convencional; o Fuji II LC apresentou o valor mais alto de todos os materiais testados. A resistência adesiva inicial do cimento de ionômero de vidro modificado por resina foi somente de $50 \%$ da resistência alcançada em 24 horas. Os autores concluíram que a resistência adesiva inicial, nos períodos seguidos à polimerização dos materiais, pode ter implicações clínicas se as restaurações forem submetidas imediatamente a tensões.

KORAN; KURSCHNER ${ }^{70}$, em 1998, propuseram-se a avaliar comparativamente o desenvolvimento, grau e profundidade de polimerização, a contração, viscosidade e dureza de superfície de uma resina composta, quando fotoativada através de duas técnicas. A primeira delas compreendeu a técnica de dois passos, sendo que as densidades de potência utilizadas foram: grupo $1-150 \mathrm{~mW} / \mathrm{cm}^{2}$ por 10 segundos $+500 \mathrm{~mW} / \mathrm{cm}^{2}$ por mais 30 segundos $(16.500$ $\mathrm{mW} / \mathrm{cm}^{2}$ ); grupo $2-150 \mathrm{~mW} / \mathrm{cm}^{2}$ por 10 segundos $+700 \mathrm{~mW} / \mathrm{cm}^{2}$ por mais 30 segundos $\left(22.500 \mathrm{~mW} / \mathrm{cm}^{2}\right)$. Nos demais grupos foi utilizada a técnica de fotoativação convencional: grupo $3-500 \mathrm{~mW} / \mathrm{cm}^{2}$ por 40 segundos $\left(20.000 \mathrm{~mW} / \mathrm{cm}^{2}\right)$; grupo $4-700 \mathrm{~mW} / \mathrm{cm}^{2}$ por 40 segundos $\left(28.000 \mathrm{~mW} / \mathrm{cm}^{2}\right)$. Os dados obtidos em cada um dos testes foram analisados estatisticamente. Verificoutse que, quando se utilizou a técnica em dois passos, não houve diferença estatística em relação à contração de polimerização, à dureza de superfície ou na concentração de monômeros residuais, quando comparado à técnica convencional. Quanto ao teste de resistência adesiva (cisalhamento), observaram-se maiores valores quando se utilizou a técnica de fotoativação por dois passos. Os menores valores de resistência adesiva foram apresentados pelo grupo que utilizou maior densidade de potência (grupo 4). Sendo assim, os autores concluíram que o escoamento do material é maior quando se utilizou uma redução inicial da densidade de potência, que contribuiu para a redução da tensão de contração na cavidade durante o processo de polimerização. Desta forma, afirmaram que, clinicamente, ao 
se fotoativar o material restaurador utilizando a técnica por dois passos, esta deverá contribuir de forma significativa para uma melhor adaptação marginal.

O vetor de contração das resinas química e fotoativadas e, em particular, a afirmação de que as resinas compostas contraem em direção à luz, foram analisados por VERSLUIS; TANTBIROJN; DOUGLA $\boldsymbol{S}^{152}$, em 1998. Através da análise por elemento finito, os autores observaram que a contração de polimerização não se baseou na teoria de que os vetores de contração são direcionados para o centro do material (resinas químicas) ou para a fonte de luz (fotopolimerizáveis). Desta forma, a direção de contração não foi significativamente afetada pelo direcionamento da fonte de luz, mas determinada pela adesão da restauração à estrutura dentária e pelas superfícies livres. Nas resinas quimicamente e fotoativadas, a contração de polimerização ocorreu em direção ao centro da massa somente quando não se realizaram os procedimentos adesivos. Quando estes procedimentos foram realizados, a contração se dava em direção às superfícies aderidas, mudando-se os vetores de contração. Conseqüentemente, diferenças entre os padrões de contração das resinas auto e fotoativadas foram mínimos. Concluiu-se que as resinas compostas não se contraem em direção à luz, mas esta direção é predominantemente determinada pelo formato cavitário e pela qualidade da adesão. A direção dos vetores de contração, em resposta ao posicionamento da luz, não parece ser um critério apropriado para otimizar a qualidade marginal.

Considerando a hipótese que a fotoativação com uma baixa densidade de potência inicial poderia ser um método eficiente para reduzir as forças de tensão nas margens localizadas em esmalte, $\boldsymbol{K} \boldsymbol{A} \boldsymbol{N} \boldsymbol{C A} ; \boldsymbol{S} \boldsymbol{U} \boldsymbol{H}^{66}$, em 1999, investigaram o efeito da fotoativação por pulso na redução do estresse de uma resina composta, com margens localizadas em esmalte. Este estudo examinou a dureza superficial, resistência à tração diametral e os efeitos dos estresses de polimerização foram avaliados através da penetração do corante em cavidades de classe I $(\mathrm{C}=5)$. Os preparos foram realizados em 30 molares humanos extraídos, os quais foram restaurados com resina composta Z100 pela técnica incremental $(2 \mathrm{~mm})$. O incremento oclusal foi fotoativado através de diferentes densidades de potência e intervalos de tempo: grupo 1- $40 \mathrm{~s}$ a $600 \mathrm{~mW} / \mathrm{cm}^{2}$; grupo $2-40 \mathrm{~s}$ a $100 \mathrm{~mW} / \mathrm{cm}^{2}$; grupo $3-2 \mathrm{~s}$ a $300 \mathrm{~mW} / \mathrm{cm}^{2}+5$ minutos espera $+10 \mathrm{~s}$ a $600 \mathrm{~mW} / \mathrm{cm}^{2}$. Posteriormente, os dentes foram imersos na fucsina básica a $0,5 \%$ por 24 horas e seccionados para a avaliação da penetração do corante na interface esmalte-restauração. A dureza superficial do grupo 3 mostrou-se baixa e a 
resistência à tração diametral não apresentou diferenças significantes entre os grupos. A utilização da baixa densidade de potência resultou em significante menor penetração do corante, porém mínima infiltração foi observada no grupo que utilizou a fotoativação por pulso, acreditando-se ser o resultado de um melhor escoamento da resina composta, devido ao prolongamento do período pré-gel. Concluíram que a técnica de fotoativação por pulso pode ser importante na redução do estresse de restaurações com margens localizadas em esmalte.

$\boldsymbol{Y A M A U T I}^{154}$, em 1999, avaliou a microinfiltração em restaurações de resina composta, utilizando duas técnicas de inserção do material e cinco métodos de fotoativação. Foram confeccionadas cavidades de classe V cilíndricas, nas faces vestibular e/ou lingual de terceiros molares humanos, as quais foram restauradas com Single Bond/ Z100. Os dentes foram divididos em 10 grupos, diferindo-se pela técnica de inserção da resina composta (incremental ou única) e pelas técnicas de fotoativação do material (variação da intensidade de luz). Grupo1- inserção única (I.U) $+560 \mathrm{~mW} / \mathrm{cm}^{2}$ por $40 \mathrm{~s}$; grupo 2- IU e $180 \mathrm{~mW} / \mathrm{cm}^{2}$ por $20 \mathrm{~s}+$ aumento gradual da intensidade por $5 \mathrm{~s}+560 \mathrm{~mW} / \mathrm{cm}^{2}$ por $35 \mathrm{~s}$; grupo $3-\mathrm{IU}+$ $280 \mathrm{~mW} / \mathrm{cm}^{2}$ por $20 \mathrm{~s}+$ aumento gradual por $3 \mathrm{~s}+560 \mathrm{~mW} / \mathrm{cm}^{2}$ por $37 \mathrm{~s}$; grupos 4 , 5 e $6-$ inserção incremental (I.I) e fotoativação de acordo com os grupos 1, 2 e 3, respectivamente; grupo 7- IU com uma distância inicial de $10 \mathrm{~cm}$ entre a ponta ativa do aparelho até atingir a superfície da restauração (distância zero); grupo 8- IU com distância inicial de 5cm; grupos 9 e 10- I.I com fotoativação semelhante aos grupos 7 e 8 . Os espécimes foram submetidos à termociclagem $\left(500 \mathrm{X}, 5^{\circ} \mathrm{C}\right.$ e $55^{\circ} \mathrm{C}$ por $\left.30 \mathrm{~s}\right)$, imersão no corante e seccionamento para avaliação da infiltração. Os resultados demonstraram que as formas de inserção e de fotoativação são fatores independentes no que se refere à infiltração marginal. A técnica incremental demonstrou menor índice de infiltração marginal em relação à inserção em um único incremento. O método de fotoativação gradual, partindo de uma intensidade de luz média $\left(280 \mathrm{~mW} / \mathrm{cm}^{2}\right)$ até atingir uma intensidade máxima, demonstrou os menores valores de infiltração, com conseqüente melhor selamento marginal. A técnica de fotoativação gradual, de forma geral, apresentou menores índices de infiltração comparada à técnica convencional, mostrando eficácia em reduzir a microinfiltração.

$\boldsymbol{L} \boldsymbol{O} \boldsymbol{S C H} \boldsymbol{E}^{76}$, em 1999, investigou se os bons resultados de adaptação marginal alcançados com a técnica de fotoativação em três incrementos, preconizada por Lutz em 1986, são atribuídos somente aos efeitos do direcionamento da polimerização ou se a redução da 
intensidade de luz também é considerada um fator relevante. Cavidades de classe II tipo slot foram confeccionadas, com margens cervicais localizadas $0,5 \mathrm{~mm}$ acima da junção amelocementária, as quais foram restauradas com a resina composta Herculite XR em três incrementos. Foram utilizadas matrizes metálicas, estabilizadas com cunhas de madeira, quando a fotoativação foi realizada por oclusal e matrizes de poliéster, estabilizadas com cunhas refletivas, quando a fotoativação foi realizada através da técnica de Lutz (por cervical, vestibular e lingual). Foram comparadas técnicas de fotoativação em alta e baixa intensidade, sendo que a mesma densidade de potência foi irradiada sobre os incrementos tanto pela polimerização por oclusal, quanto pela polimerização em três passos. Para isto, foram utilizados fotodetectores para que se padronizasse a intensidade de luz irradiada sobre cada incremento de resina, tanto na fotoativação por oclusal quanto na de três passos. O tempo de exposição da luz foi de 60 segundos para cada incremento. Após o armazenamento dos dentes em água por 21 dias e a termociclagem $\left(2000\right.$ ciclos a $5^{\circ} \mathrm{C}$ e $\left.55^{\circ} \mathrm{C}\right)$, réplicas foram produzidas para a avaliação das margens das restaurações, através do microscópio eletrônico de varredura. Os resultados nas margens oclusais e verticais mostraram que a adaptação foi considerada satisfatória e não houve diferença significante entre os grupos. Nas margens cervicais, observou-se a influência de uma contração rápida e de grande magnitude com altas intensidades de luz. Após a termociclagem, verificou-se um aumento de defeitos marginais em ambos os grupos fotoativados em baixa intensidade de luz, justificado em função da polimerização pós-irradiação. A intensidade de luz foi um fator significante, enquanto que a técnica incremental não teve influência significante. $\mathrm{O}$ autor concluiu que os bons resultados encontrados com a fotoativação através da técnica dos três passos não devem ser atribuídos ao efeito da fotoativação guiada, mas à polimerização com intensidade de luz reduzida.

Os efeitos da intensidade de luz e tempo de exposição têm sido relacionados com a formação de fendas marginais em restaurações de resinas compostas. Desta maneira, $\boldsymbol{S M A L L} \boldsymbol{L}^{135}$, em 1999, mencionou que novos aparelhos fotopolimerizadores têm surgido no mercado, enfatizando os lançamentos mais recentes das lâmpadas de arco plasma e dos lasers. Comentou que muitos pesquisadores têm verificado que a alta intensidade de luz proporcionada pode causar problemas diversos, como maior contração da resina e infiltração marginal, enquanto que a fotoativação das resinas com baixa intensidade inicial, seguida de alta intensidade, resulta em uma melhor adaptação marginal. A controvérsia seria se a luz deveria ser aplicada de modo contínuo, como recomendado previamente, ou seqüencialmente 
com diferentes intensidades. Pesquisas demonstraram que o escoamento da resina é maior quando do emprego de baixas intensidades iniciais, reduzindo, assim, a tensão de contração durante a polimerização e proporcionando melhor integridade marginal. Afirmou ainda que se as paredes cavitárias são tratadas adequadamente com os sistemas adesivos, quando a resina composta for fotoativada, será direcionada para as paredes e não para a fonte de luz. Contudo, este conceito é influenciado pelo formato da cavidade e pela tensão que ocorre no material durante a polimerização. $\mathrm{O}$ autor concluiu sugerindo que, durante a aquisição de um aparelho, deve ser considerada a sua capacidade de ajuste do tempo e da intensidade para a obtenção de melhores resultados.

YOSHIKAWA et al ${ }^{159}$, em 1999, testaram a hipótese de que a resistência de união da resina composta em cavid ades tipo caixa (Classe I) seria reduzida em função da configuração cavitária e da profundidade dentinária, utilizando o teste de microtração. Em um grupo foram utilizados terceiros molares, nos quais um corte ao nível do esmalte oclusal objetivou a remoção do mesmo e a exposição de dentina superficial $(\mathrm{C}=1)$. Em outro grupo, cavidades de $3 \mathrm{~mm}$ de comprimento por $4 \mathrm{~mm}$ de largura foram preparadas com uma profundidade de $2 \mathrm{~mm}$ abaixo da superfície planificada $(\mathrm{C}=3)$. Para realizar a adesão em dentina profunda sem paredes, ou seja, em dentina plana $(\mathrm{C}=1)$, as paredes cavitárias de outro grupo foram removidas, pela secção das paredes verticais da Classe I simulada. Os adesivos utilizados foram o Clearfil Liner Bond II System (LBII), One-Step (OS) e Super-Bonded D Liner (DL), seguidos das restaurações com a resina composta (Clearfil Photo Posterior). Após o armazenamento em água por 24 horas, os dentes foram seccionados em fatias verticais $(0,7 \mathrm{~mm}$ de espessura), paralelas ao longo eixo do dente e, em seguida, montadas no aparelho de teste para serem submetidas à tração de $1 \mathrm{~mm} / \mathrm{min}$. na máquina de teste universal. De acordo com os resultados, pôde-se observar que todos os grupos apresentaram alta resistência de união em dentina superficial, mas o OS e DL apresentaram uma significante queda na resistência em dentina profunda com $\mathrm{C}=1$. Quando o fator $\mathrm{C}$ foi aumentado para 3 , houve uma queda na resistência de união para todos os materiais (21 a 35\%), mas estatisticamente significante somente com o DL. Concluíram que alguns sistemas adesivos não se aderem adequadamente em dentina profunda, sendo mais susceptíveis às tensões de contração desenvolvidas em cavidades que apresentam alto fator $\mathrm{C}$. 
Diversos materiais restauradores, que têm surgido no mercado, necessitam ser fotoativados através de aparelhos destinados para este fim. Por esse motivo, TATE; PORTER; DOSCH ${ }^{141}$, em 1999, enfatizaram que os aparelhos fotopolimerizadores sejam averiguados quanto à intensidade de luz emitida, com o intuito de proporcionarem adequada polimerização do material. Para isso, sugeriram que a intensidade irradiada seja aferida rotineiramente, utilizando-se um radiômetro. Comentaram que fatores tais como espessura, tamanho das partículas e cor do material restaurador, assim como o fator $\mathrm{C}$ e a distância entre superfície do material e fonte de luz podem afetar a transmissão da luz através do mesmo. Adicionalmente, variações na intensidade de luz podem também ser causadas por fatores como alteração de voltagem, degradação do bulbo da lâmpada ou do filtro, fratura de filamentos da fibra óptica flexível, contaminação por restos de resina composta na ponta do aparelho e quebra dos componentes deste aparelho. Desta forma, os autores concluíram que o monitoramento e manutenção freqüentes dos aparelhos fotopolimerizadores são necessários para assegurarem uma adequada polimerização do material restaurador.

SILVA E SOUZA JÚNIOR; GONÇALVES; MONDELLI ${ }^{133}$, em 1999, avaliaram o efeito da interposição do ionômero de vidro modificado por resina entre a estrutura dentária e a resina composta, submetendo os dentes restaurados às tensões térmica e mecânica, previamente à inserção no corante, para determinar o grau de infiltração marginal. Cavidades de classe II (MOD) foram realizadas em 60 pré-molares, com as margens gengivais localizadas em esmalte. Os dentes foram divididos em dois grupos, os quais foram restaurados com o Scotchbond Multi-Uso/ Z100 ( $\mathrm{n}=30)$ ou com o Optibond/ Herculite XRV ( $\mathrm{n}=30)$. Em todos os dentes, o ionômero de vidro Vitrebond foi aplicado em uma das caixas proximais. Posteriormente, os dentes foram subdivididos em três grupos $(n=20)$ : a- não foram submetidos a nenhum tipo de tensão (controle); b- submetidos à ciclagem térmica (500 ciclos, $5^{\circ} \mathrm{C}$ e $55^{\circ} \mathrm{C}$ por $15 \mathrm{~s}$ ); c- submetidos à tensão mecânica. Todos os espécimes foram imersos em fucsina básica a $0,5 \%$ por 24 horas, lavados e seccionados para avaliar a extensão da penetração do corante através de escores. Verificoutse que os dentes restaurados com o Optibond/ Herculite XRV apresentaram menores índices de infiltração marginal, comparados aos restaurados com o Scotchbond/ Z100. Os espécimes submetidos à tensão térmica não apresentaram aumento nos níveis de infiltração em relação ao grupo controle, para ambos os sistemas avaliados. As restaurações realizadas com o sistema Optibond/ Herculite XRV, quando submetidas ao estresse mecânico, apresentaram significante maior infiltração do 
corante nas caixas que não receberam a interposição do ionômero de vidro Vitrebond. Concluíram que o estresse térmico não foi capaz de induzir a uma maior infiltração marginal quando comparado aos espécimes não termociclados e que o cimento de ionômero de vidro deve ser utilizado como material intermediário, principalmente nas restaurações de resina composta em dentes posteriores.

O objetivo do estudo de MUENCH; SILVA; BALLESTER ${ }^{94}$, em 2000, foi avaliar os substratos dentinários humano e bovino nos testes de resistência adesiva de três sistemas adesivos (Prime\&Bond, Single Bond e Etch\&Prime 3.0). Foram utilizados molares humanos extraídos, incisivos bovinos e molares humanos isentos de cárie, adquiridos cinco anos após a exumação dos corpos. Neste último grupo, os dentes foram armazenados secos por 6 meses e, posteriormente, reidratados em água destilada por 30 dias previamente aos procedimentos adesivos. Após a confecção dos espécimes com os sistemas adesivos acima referidos e a resina composta $\mathrm{TPH}$, realizaram-se os testes de resistência adesiva. Os resultados não mostraram diferenças na resistência adesiva entre os substratos dentinários humano e bovino, independente do sistema adesivo utilizado. Os autores concluíram que nem o tipo de substrato dentinário (humano ou bovino), nem a forma de armazenamento tiveram influência significante na resistência adesiva à tração.

Em 2000, SILVA et al. ${ }^{130}$, avaliaram a infiltração marginal em cavidades de classe V restauradas com um cimento de ionômero de vidro convencional, dois híbridos e um compômero. Foram realizados 40 preparos no total nas faces vestibulares e linguais de dentes humanos, com margens localizadas em esmalte e cemento, respectivamente. Realizaram-se 10 restaurações com cada tipo de material: convencional (Vidrion R), híbridos (Vitremer e Variglass) e compômero (Dyract). Os dentes foram termociclados no corante e seccionados para avaliação do grau de infiltração. Não houve diferença estatisticamente significante entre os materiais para o grupo esmalte, contudo, para o grupo cemento, observaram-se diferenças significantes, onde o convencional e o híbrido (Vitremer) apresentaram os melhores resultados, sem diferença significante entre eles.

$\boldsymbol{H A G G E} \boldsymbol{e t} \boldsymbol{a l} .^{59}$, em 2000, avaliaram a infiltração marginal de restaurações de resina composta com interposição de cinco materiais intermediários. Preparos de classe II foram realizados em 60 molares, com margens gengivais localizadas $1 \mathrm{~mm}$ além da junção amelo- 
cementária. Quatro grupos de 12 dentes foram condicionados por 20 segundos, lavados pelo mesmo tempo, e levemente secos. O Prime \& Bond NT (Dentsply) foi aplicado e fotoativado; a resina Surefil foi inserida em 2 incrementos, fotoativados por 40 segundos. Esse tratamento foi repetido em três grupos adicionais, porém, com a inclusão de material intermediário de resina fluida (Revolution/E\&D), de compômero fluido (Dyract Flow/Dentsply) e de resina de polimerização química (Bisfil 2B/Bisco). O quinto grupo de dentes foi condicionado com ácido poliacrílico, por 10 segundos, lavado e seco; o cimento de ionômero de vidro modificado por resina Fuji II LC (GC) foi aplicado e fotoativado para posterior aplicação da resina, como nos grupos acima especificados. Os dentes foram termociclados (1.000 ciclos, $5^{\circ} \mathrm{C}-55^{\circ} \mathrm{C}$ ), selados e imersos em fucsina básica a $5 \%$, por 24 horas. Depois, seccionados para análise da microinfiltração. Os resultados demonstraram que nas restaurações onde o ionômero de vidro modificado por resina foi aplicado como base, a infiltração marginal foi significativamente menor que nos demais grupos. Os autores concluíram que a associação cimento de ionômero de vidro/ resina composta é eficaz para a redução da infiltração marginal.

VERONEZI ${ }^{149}$, em 2000, verificou a influência do número de ciclos no processo de ciclagem térmica para o estudo da infiltração marginal de restaurações de resina composta, além de comparar os métodos de avaliação desta microinfiltração. Foram confeccionadas cavidades circulares em 76 pré-molares, localizadas em cemento e/ ou dentina, as quais foram restauradas com o sistema Scotchbond Multi Purpose Plus e resina composta Z100. Após o polimento, os dentes foram divididos em 4 grupos que se diferenciaram pelo número de ciclos térmicos empregados: 1- não termociclado (controle); 2- 100 ciclos; 3- 200 ciclos; 4 - 1000 ciclos, nas temperaturas de $5^{\circ} \mathrm{C}$ e $55^{\circ} \mathrm{C}$, com imersão de $15 \mathrm{~s}$ em cada banho. Em seguida, todos os dentes foram colocados em fucsina a 0,5\% por 24 horas, incluídos em resina poliestirênica e seccionados para análise da microinfiltração. Os cortes foram avaliados pelos métodos qualitativo (escore) e quantitativos (linear e área), no programa de computador Image Tools. Com base nos resultados, apesar do grupo 1 apresentar menor infiltração do corante, pode-se concluir que a termociclagem não demonstrou influência estatisticamente significante na microinfiltração em restaurações de resina composta, quando comparados os grupos que receberam ciclagem térmica com o não termociclado. Os métodos qualitativo e quantitativos mostraram-se equivalentes para medir a infiltração do corante pela interface adesiva. 
Em uma revisão de literatura realizada por $\boldsymbol{D} \boldsymbol{A} \boldsymbol{V I D S O N}$; de $\boldsymbol{G E} \boldsymbol{E}^{35}$, em 2000, os autores comentaram que a ativação da canforoquinona, o iniciador mais comumente presente nas resinas compostas, é de suma importância para o início da reação de polimerização do material, desde que a irradiação seja feita em um comprimento de onda de 470nm. No entanto, para uma adequada conversão da resina é necessária uma certa quantidade de energia, a qual pode ser aplicada de diferentes formas, sendo dependente das características da fonte de luz e da duração da exposição. Uma completa conversão pode não ser possível nas áreas mais profundas da restauração, principalmente se aparecerem defeitos em algum componente da lâmpada, risco que pode ser minimizado prolongando-se o tempo de exposição à luz. Enfatizaram que a conversão da resina composta está sempre associada à contração do material, contudo, uma forma de moderar as tensões provenientes da mesma é a utilização da fotoativação com baixa seguida de alta intensidade de luz, cuja técnica pode ser aplicada com recentes aparelhos fotopolimerizadores existentes no mercado, como o Elipar (Espe) e o VIP (Bisco). Fontes de arco plasma, como o Apollo 95E, também são citadas por irradiarem alta intensidade de luz contínua, em um estreito comprimento de onda e por um curto tempo de exposição. O emprego de alta intensidade de luz inicial gera uma rápida contração da resina, a qual pode afetar negativamente a integridade marginal das restaurações. Assim, os autores consideraram que é necessário o entendimento dos possíveis efeitos da intensidade de luz sobre a geração das tensões de contração e que uma maior qualidade marginal pode ser obtida, através do uso de bases cavitárias que absorvam essas tensões e da utilização da técnica de fotoativação gradual.

A influência da fotoativação soft-start na integridade marginal de duas resinas modificadas por poliácidos e de uma resina composta foi testada por FRIEDL et al. ${ }^{52}$, em 2000. Sessenta cavidades de classe V tipo caixa foram preparadas na face vestibular, com margem gengival $1 \mathrm{~mm}$ abaixo da junção amelo-cementária. Vinte restaurações foram realizadas com cada um dos três materiais: grupo 1- Prime \& Bond 2.1/ resina composta Spectrum (SP); grupo 2- Prime \& Bond 2.1/ Dyract (DY); grupo 3- OSB Primer/ Hytac (HY), sendo que os mesmos foram inseridos em um único incremento. Diferentes métodos de fotoativação foram utilizados, onde 10 restaurações de cada grupo foram fotoativadas convencionalmente por $40 \mathrm{~s}$ a $800 \mathrm{~mW} / \mathrm{cm}^{2}$ e, as outras 10 restaurações, a $150 \mathrm{~mW} / \mathrm{cm}^{2}$ por $10 \mathrm{~s}$ $+800 \mathrm{~mW} / \mathrm{cm}^{2}$ por 30s. As fendas marginais foram avaliadas antes e após a ciclagem termomecânica $\left(500\right.$ ciclos a $5^{\circ} \mathrm{C}$ e $55^{\circ} \mathrm{C}$ por 30 segundos; $\left.72,5 \mathrm{~N}\right)$, e a microinfiltração foi 
analisada através da penetração do corante (fucsina básica a 0,5\%). Observou-se que o método de fotoativação soft-start (gradual) não proporcionou melhora na adaptação marginal dos diferentes materiais testados, antes e após o tratamento termomecânico. Contudo, após a ciclagem termomecânica, menor ocorrência de fendas foi encontrada nas margens em esmalte para a SP (0\%), comparada a DY $(15,5 \%)$ e HY (44,5\%), mediante a utilização do método gradual de fotoativação. Na interface dentina-restauração, não houve diferença significante entre os materiais $(29,6 \%$ para o SP; $8,5 \%$ para o DY e $21 \%$ para HY) antes e após o tratamento termomecânico, quando da utilização da técnica de fotoativação gradual. Com relação à microinfiltração, a penetração do corante foi maior para a resina composta na interface dentina-material restaurador, enquanto que as resinas modificadas por poliácidos mostraram melhor adaptação marginal, concluindo que se adaptam melhor ao substrato dentinário. Os autores concluíram que a técnica de fotoativação gradual não proporcionou melhora na adaptação marginal da resina composta ou das resinas modificadas por poliácidos, utilizadas em cavidades de classe V.

BRACKETT; HAISCH; COVE $\boldsymbol{Y}^{16}$, em 2000, compararam a microinfiltração de duas resinas compostas fotoativadas com luz halógena ou com a fonte de arco plasma, em cavidades de classe V. Os preparos foram confeccionados nas faces vestibulares e linguais de 16 terceiros molares extraídos, com margens localizadas na junção amelo-cementária. As cavidades foram restauradas com as resinas compostas Z250 e Amelogen pela técnica incremental e fotoativadas por dois diferentes métodos. No primeiro, cada incremento foi fotoativado por 40 segundos com fonte de luz halógena (XL 3000) e, no segundo, cada incremento foi fotoativado por 10 segundos com o aparelho de arco plasma (PAC Light), com potências aproximadas de $450 \mathrm{~mW} / \mathrm{cm}^{2}$ e $1.440 \mathrm{~mW} / \mathrm{cm}^{2}$, respectivamente. Após o armazenamento dos dentes em água durante uma semana, foram termociclados a $5^{\circ} \mathrm{C}$ e $55^{\circ} \mathrm{C}$ em banhos de 1 minuto, perfazendo um total de 2.500 ciclos. Posteriormente, os espécimes foram selados com esmalte de unha, imersos no corante por 4 horas e seccionados longitudinalmente pelo centro das restaurações, para a avaliação da infiltração. Os resultados revelaram ausência de infiltração na interface esmalte - resina composta em todas as amostras analisadas, enquanto que as maiores infiltrações foram observadas nas paredes cavitárias cervicais para cada combinação método de fotoativação/ material restaurador. Porém, observou-se que não houve interação entre material restaurador e método de fotoativação. As restaurações fotoativadas com o sistema arco plasma revelaram maior incidência de 
infiltração. Segundo os autores, isto ocorreu provavelmente devido a uma rápida polimerização, a qual pode ter produzido tensões excessivas nas ligações adesivas, ou a uma incompleta polimerização da resina composta, o que acarretou em uma fraca adesão e conseqüente aumento da microinfiltração. Os autores concluíram que a utilização da fonte de arco plasma parece aumentar o risco de infiltração nas margens dentinárias, enquanto que a adaptação marginal na interface esmalte-resina composta mostra-se adequada, com ambos os métodos de fotoativação.

O aumento na demanda de procedimentos adesivos levou ao desenvolvimento de tecnologias avançadas para a polimerização de certos materiais restauradores. O propósito do estudo de STRITIKUS; $\boldsymbol{O} \boldsymbol{W E N} \boldsymbol{S}^{137}$, em 2000, foi avaliar in vitro a microinfiltração de selantes e restaurações de resina composta, utilizando dois diferentes aparelhos fotopolimerizadores (fonte halógena e fonte de arco plasma). Quarenta e oito dentes foram selecionados e divididos em 4 grupos de 12. No primeiro e terceiro grupos foi aplicado o selante Delton Plus na superfície oclusal, enquanto que o segundo e quarto grupos foram restaurados de forma incremental (incrementos de 1mm), com a resina composta Z100 (3M), em cavidades de classe I oclusais. Os materiais dos grupos 1 e 2 foram fotoativados por 10 segundos com o aparelho Arco Plasma KCP 1000, e os grupos 3 e 4 com a fonte de luz halógena (Ortholux) por 40 segundos. Os dentes restaurados foram armazenados em água destilada por uma semana e, a seguir, realizaram-se 200 ciclos de ciclagem térmica nas temperaturas de $5^{\circ} \mathrm{C}$ e $55^{\circ} \mathrm{C}$. Após a imersão dos mesmos no corante, fez-se o seccionamento longitudinal para análise da microinfiltração por escores. Observou-se que a fotoativação por 10 segundos com o sistema Arco Plasma mostrou-se insuficiente para a polimerização da resina composta, enquanto que os selantes não apresentaram infiltração quando da utilização deste aparelho. Os autores relataram que, possivelmente um maior tempo de exposição com este tipo de aparelho, poderia proporcionar menor microinfiltração. As restaurações de resina composta apresentaram menor infiltração quando fotoativadas com o aparelho convencional. No entanto, estudos precisam ser realizados para avaliar se uma alta intensidade de luz pode ser responsável por altos níveis de contração do material. Assim, esta contração poderia ser responsável pelo aumento da microinfiltração nas restaurações fotoativadas com o aparelho de arco plasma. Sugeriram que o sistema Arco Plasma poderia ser melhor utilizado para polimerizar selantes e/ou possivelmente brackets ortodônticos. A fotoativação convencional mostrou ser a melhor opção para a polimerização de restaurações Classe I de resina composta. 
Um importante estudo foi realizado por $\boldsymbol{E R} \boldsymbol{N S T} \boldsymbol{e t} \boldsymbol{a l}{ }^{43}$, em 2000, no qual examinaram o efeito da fotoativação gradual na redução do estresse de diferentes materiais restauradores fotopolimerizáveis. Para cada material utilizado, um mínimo de 10 espécimes foram confeccionados e fotoativados a $700 \mathrm{~mW} / \mathrm{cm}^{2}$ por $40 \mathrm{~s}$, enquanto que outros 10 espécimes foram fotoativados a $150 \mathrm{~mW} / \mathrm{cm}^{2}$ por $10 \mathrm{~s}$, aumentando automaticamente para $700 \mathrm{~mW} / \mathrm{cm}^{2}$ por $30 \mathrm{~s}$. Os autores observaram que a utilização da técnica gradual reduziu significativamente o estresse na maioria dos materiais testados, cujo mecanismo parece ser devido a um maior escoamento do material durante a fase pré-gel. Entretanto, este efeito parece ser menos efetivo nas resinas que contêm maior concentração de fotoiniciadores ou em materiais que são mais elásticos, como os compômeros.

Considerando que a fotoativação da resina composta gera a contração de polimerização do material, podendo contribuir para o aparecimento da infiltração marginal, DENNISON et al..$^{40}$, em 2000, investigaram o efeito de diferentes intensidades de luz na contração de polimerização de duas resinas compostas: híbrida e de micropartículas. O teste de dureza também foi realizado para avaliar a efetividade de cada intensidade na polimerização do material. Os espécimes foram confeccionados com as resinas TPH e Silux Plus e quatro grupos de doze espécimes foram avaliados quanto à contração de polimerização, de acordo com a intensidade de luz utilizada: intensidade máxima - 100\% por 40s (a), baixa intensidade - $25 \%$ por 40 s (b), aumentos seqüenciais da intensidade de luz - $25 \%$ por $20 \mathrm{~s}+$ $50 \%$ por $10 \mathrm{~s}+100 \%$ por $10 \mathrm{~s}$ (c) e $25 \%$ por $10 \mathrm{~s}+50 \%$ por $10 \mathrm{~s}+100 \%$ por $20 \mathrm{~s}$ (d). Os resultados revelaram diferenças significantes entre a intensidade máxima (maior tensão de contração) e os demais grupos para ambos os materiais, no entanto não foram observadas diferenças entre os três últimos grupos. A utilização da fotoativação seqüiencial (d) mostrou reduzir significativamente a contração de polimerização das duas resinas compostas testadas, sem comprometer a profundidade de polimerização. Os autores afirmaram que as propriedades mecânicas não foram afetadas quando o método seqüencial incluiu pelo menos 20s de irradiação final, com máxima intensidade de luz. Concluíram que a fotoativação gradual foi capaz de reduzir a velocidade da contração de polimerização das resinas compostas sem, no entanto, comprometer a profundidade de polimerização.

Em 2000, BOUSCHLICHER; RUEGGEBERG ${ }^{14}$ avaliaram o desenvolvimento de tensão e o grau de conversão de uma resina composta híbrida, quando submetida a diferentes 
métodos de fotoativação. Confeccionaram-se espécimes de resina composta (Pertac II), os quais foram polimerizados, utilizando-se quatro diferentes técnicas de fotoativação: convencional a $800 \mathrm{~mW} / \mathrm{cm}^{2}$ por $40 \mathrm{~s}$ (STD), aumento gradual de $150 \mathrm{~mW} / \mathrm{cm}^{2}$ até $800 \mathrm{~mW} / \mathrm{cm}^{2}$ por $15 \mathrm{~s}+800 \mathrm{~mW} / \mathrm{cm}^{2}$ por $25 \mathrm{~s}(\mathrm{EXP}), 150 \mathrm{~mW} / \mathrm{cm}^{2}$ por $10 \mathrm{~s}+800 \mathrm{~mW} / \mathrm{cm}^{2}$ por $30 \mathrm{~s}(\mathrm{STEP})$, $400 \mathrm{~mW} / \mathrm{cm}^{2}$ por $80 \mathrm{~s}$ (MED). As forças provenientes da contração de polimerização foram avaliadas e comparadas entre os grupos e o grau de conversão obtido com as técnicas STD, EXP e MED, verificadas em três profundidades (superficial, a $1 \mathrm{~mm}$ e a $2 \mathrm{~mm}$ ). Os resultados mostraram que as forças máximas de contração foram significativamente menores com a utilização da fotoativação em rampa (EXP). A intensidade intermediária (MED) também resultou em um menor desenvolvimento das forças quando comparada ao STD e ao STEP, porém o MED resultou em um maior grau de conversão que o EXP em uma profundidade de $2 \mathrm{~mm}$. A técnica em rampa (EXP) foi capaz de tornar mais lento o grau de conversão do material na superfície e $1 \mathrm{~mm}$ abaixo, contudo apresentou um grau de conversão estatisticamente equivalente à técnica convencional (STD). Os autores concluíram que a menor velocidade de conversão do material observada com a técnica em rampa colaborou para reduzir a tensão proveniente da polimerização, o que não comprometeria as propriedades físicas desses materiais, uma vez que graus similares de conversão foram obtidos entre esta técnica e a convencional.

No mesmo ano, $\boldsymbol{Y A P}$ et $\boldsymbol{a l} .{ }^{156}$ investigaram as mudanças dimensionais das resinas compostas convencional (TPH) e modificada por poliácidos (Dyract) e o efeito da hidratação na contração de polimerização. Foram confeccionados espécimes das duas resinas e, após a fotoativação, a contração de polimerização linear das mesmas foi medida em estado livre, quando armazenadas em água a $37^{\circ} \mathrm{C}$, ou quando deixadas no ar a $26^{\circ} \mathrm{C}$, por um período de um mês. Os resultados mostraram que a reação de polimerização de ambos os materiais foi acompanhada por mudanças dimensionais. Os índices de contração para as duas resinas foram maiores durante a reação de polimerização e continuaram após a remoção da fonte de luz. Quando armazenadas em água, a contração máxima foi observada em uma hora tanto para a TPH quanto para a Dyract, o que foi seguido por uma expansão que ocorreu desde um dia até um mês. A resina modificada por poliácidos apresentou significante menor contração de polimerização que a convencional, após um mês de armazenamento em água. Os autores concluíram que a contração das resinas convencional e modificada por poliácidos continua após a remoção da fonte de luz e é maior em uma hora. Assim, se as restaurações realizadas 
com esses materiais forem polidas imediatamente após a fotoativação, elas deverão ser analisadas após um mês, para determinar se requerem um repolimento.

TAPETY ${ }^{140}$, em 2001, avaliou in vitro a microinfiltração em cavidades classe II restauradas com três sistemas restauradores para dentes posteriores (P60/Single Bond; Solitaire/Gluma One Bond e SureFil/Prime \& Bond 2.1), com interposição de bases (uma resina de baixa viscosidade - Flow-It e um ionômero de vidro modificado por resina Vitremer). Nos grupos controle, nenhuma base foi utilizada. Cavidades MOD foram confeccionadas em 90 dentes pré- molares humanos, com as margens cervicais da caixa distal localizadas $1 \mathrm{~mm}$ aquém do limite amelo-cementário e, da caixa mesial, $1 \mathrm{~mm}$ além deste limite. Os dentes foram divididos em 9 grupos de 10 espécimes, como descritos a seguir: grupos I, II e III: receberam Flow-It como base e foram restaurados com P60, Solitaire e SureFil, respectivamente; grupos IV, V e VI: foram apenas restaurados com as resinas P60, Solitaire e SureFil, respectivamente; grupos VII, VIII e IX: receberam Vitremer como base e foram restaurados com P60, Solitaire e SureFil, respectivamente. As bases foram mantidas na parede gengival ao nível da junção amelo-dentinária na caixa distal, e a $1 \mathrm{~mm}$ do cavosuperficial na caixa mesial. Posteriormente, os dentes foram submetidos ao estresse mecânico (1-17kg, 10x a cada dia/7 dias), imersos em fucsina básica por 24 horas e seccionados para avaliação da infiltração. A área de penetração do corante foi calculada pelo programa de computador Image Tool (UTHSCSA), após o escaneamento dos espécimes. A análise dos resultados demonstrou que as margens em esmalte apresentaram menores áreas infiltradas, independentemente do material utilizado e das associações entre eles. A presença de base não resultou em redução significante da infiltração marginal para as resinas P60 e SureFil, independente da margem avaliada. A resina Solitaire apresentou os maiores níveis de infiltração quando empregada sem a presença de base. Assim, concluiu-se que a presença de base pode minimizar os níveis de infiltração, nas margens em esmalte e dentina, porém está na dependência do sistema restaurador empregado.

Geralmente, em cavidades de classe V, a contração de polimerização das resinas compostas compete com a resistência adesiva dos sistemas adesivos e desafia a integridade marginal, especialmente nas margens localizadas em dentina. Partindo-se desse pressuposto, MANHART et $\boldsymbol{a l} .^{79}$, em 2001, avaliaram a qualidade marginal e a microinfiltração de diferentes sistemas adesivos e suas correspondentes resinas compostas em cavidades de classe 
V. Preparos padronizados foram confeccionados em 90 molares, com margens cervicais em dentina. Os dentes foram aleatoriamente divididos em 9 grupos $(n=10)$, cujas cavidades foram restauradas com diferentes sistemas restauradores: Syntac Sprint/ Tetric Ceram (SS); Syntac Single-Component/ Tetric Ceram (SC); Onestep/ Aeliteflo (OS); Aquaprep + Onestep/ Aeliteflo (AO); Prime \& Bond 2.1/ TPH (PB); Optibond Solo/ Prodigy (OP); Single Bond/ Z100 (SB); Tenure Quik/ Marathon (TQ); Solobond M/ Arabesk (SM). As resinas compostas foram inseridas em um único incremento e fotoativadas por $40 \mathrm{~s}$ de forma gradual. Posteriormente, os dentes foram submetidos à termociclagem $\left(1000\right.$ ciclos a $5^{\circ} \mathrm{C}$ e $55^{\circ} \mathrm{C}$ por 30s em cada banho). Réplicas foram realizadas com resina epóxica para a avaliação da qualidade marginal, em microscópio eletrônico de varredura. Para a análise da microinfiltração, os dentes foram cobertos com esmalte de unha, imersos em azul de metileno e seccionados no sentido vestíbulo-lingual. O SC mostrou maiores porcentagens de margens bem seladas ao MEV quando comparado ao OS e SM, em esmalte e dentina, respectivamente. No esmalte, o Single Bond demonstrou mais margens perfeitas que o SM. A análise de microinfiltração revelou maiores infiltrações em dentina para o TQ, SC, SS, SB, PB e OS. Os autores concluíram que nenhum dos sistemas restauradores testados garantiu um perfeito selamento marginal, tanto na dentina quanto no esmalte em cavidades de classe V.

LUCENA-MARTIN et $\boldsymbol{a l}^{77}$ avaliaram a microinfiltração de restaurações de resina composta em cavidades de classe $\mathrm{V}$, mediante a utilização de diferentes sistemas adesivos, além de estudar a influência da termociclagem e do tempo de imersão no corante. Os preparos foram confeccionados na superfície vestibular de 90 dentes humanos, com margens em esmalte e cemento/dentina. Os dentes foram divididos em 6 grupos de 15 cada para avaliação de seis sistemas adesivos dentinários (One Step, Prime\&Bond 2.0, Syntac Single, Single Bond, Optibond Solo e Syntac Sprint), os quais foram aplicados previamente a inserção da resina composta Degufill Ultra. Cada grupo foi dividido em 3 subgrupos $(n=5)$ : a- os espécimes foram imersos no corante por 7 dias; b- imersão no corante por 31 dias e c- os espécimes foram termociclados $\left(500 \mathrm{X}, 5^{\circ} \mathrm{C}\right.$ e $55^{\circ} \mathrm{C}$ por $\left.30 \mathrm{~s}\right)$ e imersos no corante por 7 dias. Posteriormente, todos os dentes foram seccionados para avaliar a penetração do corante através de escores. Os resultados revelaram que todos os sistemas adesivos apresentaram mínima infiltração nas margens localizadas em esmalte e maior penetração do corante nas margens cervicais. Apesar da ocorrência de infiltração na margem cervical com a utilização de todos os sistemas adesivos, os piores resultados foram encontrados com o Syntac Single e 
Syntac Sprint. O Single Bond e Prime\&Bond mostraram significante maior infiltração do corante nas margens cervicais dos espécimes submetidos à ciclagem térmica. O Optibond Solo demonstrou os melhores resultados nas margens localizadas em dentina sob as três condições experimentais testadas. Concluíram que a adesão ao esmalte não é afetada pelo tempo ou pela termociclagem, independente do sistema adesivo utilizado, no entanto, a adesão à dentina ainda constitui-se um desafio a ser superado.

Para a realização de restaurações de resina composta, é necessária que uma intensidade de luz atue em um comprimento de onda específico para que a polimerização seja efetiva. Diante deste fato, MAZUR et $\boldsymbol{a l}^{84}{ }^{84}$ em 2001, verificaram a relação da variação das diferentes intensidades de luz com o índice de microinfiltração marginal encontrado em restaurações de classe $\mathrm{V}$, através de uma revisão de literatura. De acordo com os diversos resultados encontrados na literatura, os autores enfatizaram que para uma adequada polimerização do material, o comprimento de onda deve se encontrar entre 400nm a 550nm para que atue sobre a canforoquinona. Verificaram que uma intensidade mais baixa de luz proporciona uma polimerização insuficiente do material e a obtenção de propriedades inferiores, porém, isto pode ser compensado com a utilização de um maior tempo de exposição do material à luz. A fotoativação gradual apresentou melhores resultados quando comparada à fotoativação pelo método convencional. Adicionalmente, observaram que a técnica de inserção incremental mostrou menor infiltração marginal quando utilizados incrementos menores que $2 \mathrm{~mm}$ de espessura. Os autores afirmaram que a intensidade de luz é de fundamental importância, pois a provável infiltração marginal, dentre outras conseqüências, está diretamente relacionada à polimerização inadequada do material. Na busca de encontrar a intensidade de luz mais adequada, verificourse que nenhuma definiu um valor específico para baixas ou para altas intensidades de luz utilizadas.

LOPES et al ${ }^{75}$, em 2001, avaliaram o grau de microinfiltração de restaurações classe $\mathrm{V}$ de resina composta, utilizando cinco diferentes técnicas de fotoativação. Cinqüenta preparos classe $\mathrm{V}$, em forma de cunha, foram confeccionados nas faces vestibulares, com margens localizadas $1 \mathrm{~mm}$ abaixo e acima do limite amelo-cementário. As cavidades foram restauradas com o sistema adesivo Excite (Vivadent) e com um único incremento da resina composta Tetric Ceram (Vivadent). Os dentes foram divididos em 5 grupos $(n=10)$ e as diferentes técnicas de fotoativação foram realizadas com o aparelho VIP (Bisco). G1: 
convencional/baixa intensidade $\left(300 \mathrm{~mW} / \mathrm{cm}^{2} / 40 \mathrm{~s}\right) ; \mathrm{G} 2$ : $\operatorname{rampa}\left(300 \mathrm{~mW} / \mathrm{cm}^{2} / 20 \mathrm{~s}+\right.$ $\left.550 \mathrm{~mW} / \mathrm{cm}^{2} / 20 \mathrm{~s}\right) ; \mathrm{G} 3$ : pulso/alta intensidade $\left(550 \mathrm{~mW} / \mathrm{cm}^{2} / 5 \mathrm{~s}+5\right.$ minutos espera + $\left.550 \mathrm{~mW} / \mathrm{cm}^{2} / 35 \mathrm{~s}\right) ; \mathrm{G} 4$ : convencional/alta intensidade $\left(550 \mathrm{~mW} / \mathrm{cm}^{2} / 40 \mathrm{~s}\right) ; \mathrm{G} 5$ : pulso/baixa intensidade $\left(300 \mathrm{~mW} / \mathrm{cm}^{2} / 5 \mathrm{~s}+5\right.$ minutos espera $\left.+300 \mathrm{~mW} / \mathrm{cm}^{2} / 35 \mathrm{~s}\right)$. Posteriormente, os dentes receberam 250 ciclos de termociclagem a $5^{\circ} \mathrm{C}$ e $55^{\circ} \mathrm{C}$, com banhos de 30 segundos, para serem, em seguida, imersos no corante. Um seccionamento longitudinal foi realizado na porção central das restaurações, para a observação em um estereoscópio. Os resultados revelaram que para ambas as margens (esmalte e dentina) houve menor infiltração com a utilização da técnica de pulso/ baixa intensidade (G5) e os piores resultados, nas margens em dentina, foram encontrados com a fotoativação convencional de alta intensidade de luz (G4). Os autores sugeriram que a técnica do pulso com baixa intensidade pode melhorar a capacidade de selamento marginal de restaurações adesivas.

SAHAFI; PEUTZFELDT; ASMUSSEN ${ }^{119}$, em 2001, avaliaram o efeito da fotoativação soft-start na formação de fendas marginais em cavidades localizadas em dentina. Foram confeccionadas cavidades de classe V na superfície radicular de 64 molares humanos extraídos e as mesmas foram distribuídas em 8 grupos. Grupos 1-4: Scotchbond MultiPurpose/ Z100; Grupos 5-8: Optibond FL/ Herculite XRV. O aparelho fotopolimerizador utilizado foi o Elipar Highlight e o tempo de irradiação total foi de 40 segundos para todos os grupos, porém quatro diferentes modos de fotoativação foram seguidos: grupos 1 e 5: 40s a $750 \mathrm{~mW} / \mathrm{cm}^{2}$; grupos 2 e 6: método de passos $\left(10 \mathrm{~s}\right.$ a $100 \mathrm{~mW} / \mathrm{cm}^{2}$ seguidos de $30 \mathrm{~s}$ a $750 \mathrm{~mW} / \mathrm{cm}^{2}$ ). Nestes grupos, a ponta do aparelho permaneceu em íntimo œntato com a superfície da restauração; grupos 3 e 7: 20s com a extremidade da ponta a $2 \mathrm{~cm}$ da superfície da restauração a $100 \mathrm{~mW} / \mathrm{cm}^{2}$, seguidos de $10 \mathrm{~s}$ com a ponta aproximando-se gradativamente, e mais 10s com a ponta em contato com a superfície da restauração; grupos 4 e 8 : nos primeiros 20s foi utilizado um filtro, colocado entre a ponta do aparelho e a superfície da restauração $\left(140 \mathrm{~mW} / \mathrm{cm}^{2}\right)$, e mais $20 \mathrm{~s}$ com a ponta em contato com a restauração. Após 20 minutos do final da irradiação e armazenamento em água, as fendas marginais foram medidas e a contração calculada mediante a largura da fenda. Os resultados revelaram que o Optibond FL/ Herculite XRV mostraram menor contração que o Scotchbond Multi-Purpose/ Z100. Para ambos os sistemas restauradores, as técnicas de fotoativação soft-start avaliadas não resultaram em uma melhor adaptação marginal. Desta forma, concluíram que o método de fotoativação soft-start não foi capaz de melhorar a adaptação marginal das duas resinas 
compostas em cavidades localizadas em dentina, quando comparadas com a fotoativação convencional.

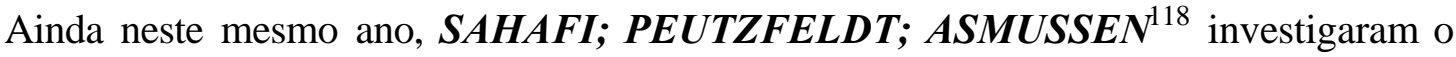
efeito da técnica de fotoativação por pulso tardio na formação de fendas marginais, em cavidades localizadas em dentina. Cavidades cilíndricas foram confeccionadas nas superfícies dentinárias de 48 molares extraídos, os quais foram aleatoriamente divididos em 8 grupos com 6 dentes cada. As restaurações foram realizadas com o Prime\&Bond NT/ Z100 e os materiais fotoativados com os aparelhos Visiolux 2 e Elipar Highlight. As restaurações do grupo 1 (controle) foram expostas a $750 \mathrm{~mW} / \mathrm{cm}^{2}$ por $10 \mathrm{~s}$. As restaurações dos grupos 2,3 e 4 foram inicialmente irradiadas por 1,2 ou $3 \mathrm{~s}$ a $425 \mathrm{~mW} / \mathrm{cm}^{2}$. Após a exposição inicial, foram colocados em água por 5 minutos e receberam uma exposição final de $750 \mathrm{~mW} / \mathrm{cm}^{2}$ por $10 \mathrm{~s}$. Os dentes dos grupos 5, 6, 7 e 8 foram inicialmente expostos a $425 \mathrm{~mW} / \mathrm{cm}^{2}$ por $2 \mathrm{~s}$ e colocados em água por 30s, 1, 3 ou 7 minutos, respectivamente, recebendo uma exposição final de $750 \mathrm{~mW} / \mathrm{cm}^{2}$ por $10 \mathrm{~s}$. Posteriormente, as restaurações foram polidas e a dimensão da fenda marginal foi medida 20 minutos após a exposição final e armazenamento em água. Os grupos 2, 3 e 4 mostraram significante menor contração que o grupo controle. Porém, as exposições iniciais por 1,2 ou $3 \mathrm{~s}$ não mostraram diferença quanto a formação de fendas. Observou-se que a fotoativação pela técnica do pulso tardio, em associação com um tempo de espera de pelo menos 1 minuto entre as exposições inicial e final, reduziu a contração do material em cavidades localizadas em dentina, quando comparada à fotoativação contínua (grupo controle). Um tempo de espera de 30s (grupo 5) resultou em uma contração similar à observada no grupo controle (grupo 1). Os autores concluíram que a técnica do pulso tardio foi efetiva em melhorar a adaptação marginal do material restaurador às paredes dentinárias.

Com o intuito de verificar se a alta irradiação proporcionada pela lâmpada de xenônio danifica a adaptação marginal de restaurações de resina composta, HASEGAWA et al ${ }^{61}$, investigaram, em 2001, o efeito das lâmpadas halógena e de xenônio quanto à adaptação marginal e à profundidade de polimerização, utilizando quatro diferentes marcas comerciais de resinas compostas. Cavidades cilíndricas foram preparadas na dentina de molares humanos extraídos. Em 120 dentes (grupo 1), aplicou-se o sistema adesivo Mega Bond e, em 180 dentes (grupo 2), foi usado um sistema adesivo experimental, previamente à aplicação das resinas compostas Clearfil APX, Estelite, Silux Plus e Z100. Cada um dos grupos foi 
subdividido em três de 40 e três de 60 dentes, respectivamente, sendo que cada material foi irradiado com o Apollo 95E por 3 segundos (lâmpada de xenônio), com o Arco Plasma Curing System por 3 segundos (lâmpada de xenônio) e com uma fonte halógena (Witelite por 40 segundos). As fendas foram medidas e a capacidade de polimerização das três fontes de luz foi avaliada através da medição da profundidade de polimerização das resinas compostas. Para medir a profundidade de polimerização, cinco espécimes foram preparados com cada resina composta, os quais foram fotoativados por 10 segundos com a lâmpada de xenônio e por 60 segundos com a halógena. Os resultados mostraram que a profundidade de polimerização obtida com a lâmpada de xenônio foi significativamente maior que a halógena em todas as resinas testadas, enquanto que a adaptação marginal não mostrou deterioração significante. A formação de fendas marginais das resinas Clearfil, Estelite e Silux Plus utilizadas com os dois sistemas adesivos foi prevenida quando os materiais foram fotoativados tanto com a fonte halógena quanto com a de arco plasma. Quando do emprego da resina Z100, as fendas avaliadas não foram significativamente diferentes com a utilização das três fontes de luz, porém quando comparada com as outras resinas compostas, revelou significante aumento das mesmas. Os autores comentaram que a utilização da lâmpada de xenônio para polimerização da resina composta tem a vantagem de reduzir o tempo clínico sem danificar a integridade marginal, se a superfície dentinária for tratada com um adequado sistema adesivo. Concluíram que a utilização da lâmpada de xenônio proporciona maior profundidade de polimerização que a fonte halógena e a adaptação marginal não se apresenta danificada.

A contração das resinas compostas ocorre durante a polimerização, afetando suas propriedades físicas e a integridade marginal. Considerando que a fotoativação gradual parece minimizar a contração desses materiais, CALDWELL; KULKARNI; TITLE $\boldsymbol{Y}^{21}$, em 2001, compararam a resistência adesiva ao cisalhamento de várias espessuras de resina composta polimerizadas através de duas diferentes técnicas de fotoativação. Terceiros molares foram incluídos em moldes e dois sistemas adesivos (Scotchbond MP ou Single Bond) foram aplicados, de modo que espécimes de 1.5, 3.0 e $4.5 \mathrm{~mm}$ de resina composta (Z100) foram confeccionados para cada sistema adesivo. Também, foram utilizados diferentes métodos de fotoativação para cada espessura de material com o aparelho Elipar Highlight (ESPE): 10s a $150 \mathrm{~mW} / \mathrm{cm}^{2}+30 \mathrm{~s}$ a $700 \mathrm{~mW} / \mathrm{cm}^{2}$ ou $40 \mathrm{~s}$ a $700 \mathrm{~mW} / \mathrm{cm}^{2}$. Posteriormente às restaurações, os dentes foram armazenados em água a $37^{\circ} \mathrm{C}$ por 7 dias. Então, o teste de resistência adesiva ao 
cisalhamento foi realizado e revelou que as diferentes espessuras de resina composta e métodos de fotoativação não mostraram diferença significante, para ambos os sistemas adesivos utilizados. Exceção foi observada com 4,5mm de espessura da resina composta, associada ao Single Bond, a qual apresentou significante menor resistência adesiva. Os resultados revelaram que com maiores espessuras de resina composta, existe uma maior tendência a ocorrer falhas adesivas/coesivas. Também, não foram verificadas diferenças na resistência adesiva quando espessuras de $1,5 \mathrm{~mm}$ e $3 \mathrm{~mm}$ foram fotoativadas por ambos os métodos. Os autores concluíram que a fotoativação do material através a técnica gradual parece não oferecer vantagens sobre a técnica convencional e que os incrementos podem ser fotoativados por ambas as técnicas, desde que não ultrapassem $2 \mathrm{~mm}$ de espessura.

YOSHIKAWA; BURROW; TAGAMI ${ }^{157}$, em 2001, realizaram um estudo para avaliar a influência de diferentes métodos de fotoativação no selamento marginal e adaptação da resina composta às paredes cavitárias, na contração de polimerização e na dureza do material. Preparos cilíndricos de classe $\mathrm{V}$ foram realizados na dentina vestibular de 50 incisivos bovinos. Os dentes foram restaurados com o sistema adesivo Clearfil Photo Bond ou SuperBond D Liner e, em seguida, restaurados com um único incremento de resina composta (Photo Clearfil Bright). As restaurações foram fotoativadas sob três diferentes intensidades de luz iniciais e tempos de exposição, seguidas por uma intensidade máxima final, distribuídas da seguinte forma: $1-600 \mathrm{~mW} / \mathrm{cm}^{2}$ por $60 \mathrm{~s} ; 2-270 \mathrm{~mW} / \mathrm{cm}^{2}$ por $10 \mathrm{~s}+5 \mathrm{~s}$ intervalo + $600 \mathrm{~mW} / \mathrm{cm}^{2}$ por $50 \mathrm{~s} ; 320 \mathrm{~mW} / \mathrm{cm}^{2}$ por $10 \mathrm{~s}+5 \mathrm{~s}$ intervalo $+600 \mathrm{~mW} / \mathrm{cm}^{2}$ por $50 \mathrm{~s} ; 4$ $270 \mathrm{~mW} / \mathrm{cm}^{2}$ por $30 \mathrm{~s}+5 \mathrm{~s}$ intervalo $+600 \mathrm{~mW} / \mathrm{cm}^{2}$ por $30 \mathrm{~s} ; 5-20 \mathrm{~mW} / \mathrm{cm}^{2}$ por $30 \mathrm{~s}+5 \mathrm{~s}$ intervalo $+600 \mathrm{~mW} / \mathrm{cm}^{2}$ por $30 \mathrm{~s}$. Após o armazenamento em água por 24 horas, os espécimes foram submetidos a 300 ciclos de termociclagem, com banhos de $30 \mathrm{~s}$ nas temperaturas de $4^{\circ}$ $\mathrm{C}$ e $60^{\circ} \mathrm{C}$. A avaliação do vedamento marginal e adaptação do material às paredes cavitárias foi realizada através da penetração do corante e seccionamento longitudinal dos espécimes. Os resultados mostraram que o melhor selamento marginal foi obtido no grupo 2 quando comparado às demais situações testadas, pois parece propiciar uma polimerização mais uniforme do material. Todos os outros métodos demonstraram certo grau de abertura marginal, com formação de fendas, mas os piores resultados foram encontrados no grupo 1. A conclusão dos autores foi que a utilização de baixa intensidade de luz $\left(270 \mathrm{~mW} / \mathrm{cm}^{2}\right)$ por $10 \mathrm{~s}$ seguida de alta intensidade $\left(600 \mathrm{~mW} / \mathrm{cm}^{2}\right)$ por 50 s proporciona melhor adaptação da resina 
composta às paredes da cavidade, por permitir a liberação das tensões induzidas pela contração de polimerização.

D'ALPINO et $\boldsymbol{a l} .^{33}$, em 2002, avaliaram a adaptação interna de restaurações de resina composta classe $\mathrm{V}$ às paredes cavitárias, utilizando três diferentes técnicas de fotoativação. As cavidades foram preparadas nas faces vestibulares e linguais de 24 terceiros molares humanos, com margens localizadas acima e abaixo da junção amelo-cementária. As restaurações foram realizadas com um único incremento, utilizando os sistemas Single Bond/ Filtek A110 (3M) e Single Bond/ Z250 (3M) no mesmo dente, nas faces vestibular e lingual. As restaurações de resina composta foram fotoativadas por meio de três técnicas: grupo 1convencional $\left(600 \mathrm{~mW} / \mathrm{cm}^{2} / 60\right.$ segundos); grupo 2- soft-start $\left(200 \mathrm{~mW} / \mathrm{cm}^{2} / 20\right.$ segundos + $600 \mathrm{~mW} / \mathrm{cm}^{2} / 40$ segundos); grupo 3- ativação por pulso $\left(200 \mathrm{~mW} / \mathrm{cm}^{2} / 3\right.$ segundos +3 minutos espera $+600 \mathrm{~mW} / \mathrm{cm}^{2} / 47$ segundos). As secções ve stíbulo-linguais foram polidas, impressas e replicadas e os espécimes foram analisados sob o microscópio eletrônico de varredura, com um aumento de 1000 vezes. A avaliação foi feita por escores de acordo com a presença ou ausência de fendas. Os resultados não mostraram diferenças significantes entre os grupos, embora infiltrações tenham sido observadas em todos. Os autores concluíram que a técnica de fotoativação e o tipo de resina utilizada não influenciaram na adaptação interna às paredes cavitárias.

MAZUR et $\boldsymbol{a l} .^{85}$, em 2002, avaliaram a microinfiltração marginal em cavidades de classe V localizadas em cemento e restauradas com resina composta, utilizando diferentes intensidades de luz, de forma gradual. Foram confeccionadas 64 cavidades em molares humanos extraídos e, para a restauração das mesmas, utilizourse o sistema adesivo Single Bond e a resina P60 pela técnica incremental. A fotoativação do material foi realizada com o aparelho Optilight 600 (Gnatus), utilizando diferentes intensidades de luz e um tempo de 20 segundos para cada incremento de resina composta. Grupo $1-100 \mathrm{~mW} / \mathrm{cm}^{2} / 300 \mathrm{~mW} / \mathrm{cm}^{2} /$ $600 \mathrm{~mW} / \mathrm{cm}^{2}$; grupo 2- $200 \mathrm{~mW} / \mathrm{cm}^{2} / 300 \mathrm{~mW} / \mathrm{cm}^{2} / 600 \mathrm{~mW} / \mathrm{cm}^{2}$; grupo $3-100 \mathrm{~mW} / \mathrm{cm}^{2} /$ $400 \mathrm{~mW} / \mathrm{cm}^{2} / 600 \mathrm{~mW} / \mathrm{cm}^{2}$; grupo 4- $200 \mathrm{~mW} / \mathrm{cm}^{2} / 400 \mathrm{~mW} / \mathrm{cm}^{2} / 600 \mathrm{~mW} / \mathrm{cm}^{2}$; grupo 5$100 \mathrm{~mW} / \mathrm{cm}^{2} / 300 \mathrm{~mW} / \mathrm{cm}^{2} / 500 \mathrm{~mW} / \mathrm{cm}^{2}$; grupo 6- $200 \mathrm{~mW} / \mathrm{cm}^{2} / 300 \mathrm{~mW} / \mathrm{cm}^{2} / 500 \mathrm{~mW} / \mathrm{cm}^{2}$; grupo 7- $100 \mathrm{~mW} / \mathrm{cm}^{2} / 400 \mathrm{~mW} / \mathrm{cm}^{2} / 500 \mathrm{~mW} / \mathrm{cm}^{2}$; grupo $8-200 \mathrm{~mW} / \mathrm{cm}^{2} / 400 \mathrm{~mW} / \mathrm{cm}^{2} /$ $500 \mathrm{~mW} / \mathrm{cm}^{2}$. Após o polimento das restaurações, os dentes foram submetidos a 300 ciclos de termociclagem nas temperaturas de $5^{\circ} \mathrm{C}$ e $55^{\circ} \mathrm{C}$, em banhos de 15 segundos. A seguir, foram 
imersos em solução de nitrato de prata e seccionados para análise da microinfiltração. Após o corte, cada espécime foi escaneado e mediu-se a penetração do corante, em milímetros, através do programa de computador Image Tools. Não houve diferença significante entre os grupos experimentais, apesar das diferentes intensidades de luz utilizadas. Concluiu- se que as diferentes intensidades de luz, aplicadas de forma gradual, não foram capazes de impedir a infiltração marginal na parede cervical de restaurações classe $\mathrm{V}$ de resina composta.

A influência das técnicas de fotoativação por pulso e soft-start na contração pós-gel da resina composta Z100, utilizando o aparelho fotopolimerizador VIP (Bisco), foi investigada por $\boldsymbol{Y A P}$; SOH; SIOW ${ }^{155}$, em 2002. Cinco espécimes foram confeccionados para cada uma das seis técnicas de fotoativação examinadas: $400 \mathrm{~mW} / \mathrm{cm}^{2}$ por 40 segundos (controle); $100 \mathrm{~mW} / \mathrm{cm}^{2}$ por 3 segundos +3 minutos espera $+500 \mathrm{~mW} / \mathrm{cm}^{2}$ por 30 segundos (pulso tardio I); $200 \mathrm{~mW} / \mathrm{cm}^{2}$ por 20 segundos +3 minutos espera $+500 \mathrm{~mW} / \mathrm{cm}^{2}$ por 30 segundos (pulso tardio II); $200 \mathrm{~mW} / \mathrm{cm}^{2}$ por 10 segundos $+600 \mathrm{~mW} / \mathrm{cm}^{2}$ por 30 segundos (soft-start); dois pulsos de $400 \mathrm{~mW} / \mathrm{cm}^{2}$ por 10 segundos e um pulso de $400 \mathrm{~mW} / \mathrm{cm}^{2}$ por 20 segundos com 10 segundos de intervalo entre eles (pulso I); 2 pulsos de $400 \mathrm{~mW} / \mathrm{cm}^{2}$ por 20 segundos com intervalo de 20 segundos entre eles (pulso II). A contração de polimerização linear foi medida de acordo com as diferentes técnicas de fotoativação durante e após esse processo, até um período de 60 minutos. Imediatamente após a fotoativação, a contração de polimerização observada com o pulso tardio I foi significativamente menor que o pulso tardio II, a soft-start e o pulso I. Um minuto após a fotoativação, a contração da resina composta com o pulso tardio I mostroutse significativamente menor, comparado ao pulso tardio II e ao soft-start. Observaram-se também diferenças significantes na contração entre o pulso tardio I e o softstart aos 10, 30 e 60 minutos, onde a contração com o pulso tardio I foi significativamente menor que o soft-start. Com relação aos tempos testados, não ocorreu diferença significante na contração pós-gel entre o grupo controle e todas as demais técnicas de fotoativação utilizadas. Os autores concluíram que as técnicas de fotoativação por pulso e soft-start não reduziram a contração pós- gel, quando comparadas à fotoativação contínua.

O objetivo do estudo de $\boldsymbol{A M A R} \boldsymbol{A L}$ et $\boldsymbol{a l} .^{4}$, em 2002, foi avaliar a influência das técnicas de fotoativação e de inserção da resina composta sobre a microinfiltração marginal e microdureza, em restaurações de classe II. Selecionaram-se 90 incisivos bovinos para a confecção de preparos tipo slot vertical, nas faces mesial e distal de cada dente, com margens 
cervicais localizadas 1mm abaixo do limite amelo-cementário. Em todos os dentes, o sistema adesivo Single Bond (3M) foi aplicado e a resina composta Z100 (A2) inserida e fotoativada, de acordo com os seguintes grupos: 1- incremento único + fotoativação convencional por 120s (40s por oclusal, 40s por lingual e 40s por vestibular); 2- técnica incremental + fotoativação convencional por 40s cada incremento; 3 - incremento único + fotoativação gradual por 120s (40s por oclusal, 40s por lingual e 40s por vestibular); 4- técnica incremental + fotoativação gradual por 40s cada incremento; 5- incremento único + fotoativação progressiva por 120s (40s por oclusal, 40s por lingual e 40s por vestibular); 6- técnica incremental + fotoativação progressiva por $40 \mathrm{~s}$ cada incremento. As intensidades de luz emitidas foram de 490 a $520 \mathrm{~mW} / \mathrm{cm}^{2}$ (convencional); $400 \mathrm{~mW} / \mathrm{cm}^{2}$ e, após $20 \mathrm{~s}, 710 \mathrm{~W} / \mathrm{cm}^{2}$ a $720 \mathrm{~mW} / \mathrm{cm}^{2}$ (gradual); enquanto que a progressiva foi realizada mediante um aumento gradual da intensidade de 160 a $600 \mathrm{~mW} / \mathrm{cm}^{2}$ em $10 \mathrm{~s}$, permanecendo em seguida na intensidade máxima. Após o polimento, as restaurações foram submetidas a 1000 ciclos de termociclagem, com banhos de 60 s nas temperaturas $5^{\circ} \mathrm{C}$ e $55^{\circ} \mathrm{C}$. Em seguida, os dentes foram imersos em azul de metileno e seccionados no centro das restaurações para a avaliação da infiltração. Não foi observada diferença significante entre as técnicas de inserção, nem entre as técnicas de fotoativação utilizadas. Concluiu-se que, independente da técnica de fotoativação ou de inserção da resina composta, a infiltração marginal foi semelhante em todos os grupos experimentais testados. Para os autores, deve-se analisar o custo-benefício de cada técnica de fotoativação e a técnica de inserção de escolha deve ser aquela que possa garantir uma boa adaptação e a polimerização adequada do material restaurador.

Ainda em 2002, AMARAL et $\boldsymbol{a l} .^{5}$ avaliaram in vitro a influência das técnicas de fotoativação convencional e soft-start na microinfiltração e microdureza de restaurações classe II de resina composta, inserida de forma incremental ou em um único incremento. Cento e vinte cavidades foram confeccionadas em dentes bovinos, as quais foram restauradas com o sistema adesivo Single Bond e a resina composta Z100. Os dentes foram divididos em 4 grupos, de acordo com a técnica de inserção e de fotoativação da resina, respectivamente: 1incremento único/convencional; 2- incremental/convencional; 3- incremento único/soft-start; 4- incremental/soft-start. Após a ciclagem térmica $\left(1000\right.$ ciclos, $5^{\circ} \mathrm{C}$ e $55^{\circ} \mathrm{C}$ por $\left.60 \mathrm{~s}\right)$, os espécimes foram imersos em azul de metileno por 4 horas, seccionados e avaliados quanto à microinfiltração. Os resultados mostraram que a técnica de inserção incremental resultou em menor infiltração marginal comparada à inserção em um único incremento, independente da 
técnica de fotoativação utilizada. A fotoativação pelo método soft-start não foi capaz de reduzir a infiltração, quando comparado ao convencional. Os menores índices de infiltração foram observados quando se associou a técnica incremental e fotoativação convencional.

CAVALCANTI; SANTOS; SILVA E SOUZA JÚNIOR ${ }^{25}$ avaliaram, em 2002, a influência da intensidade de luz no selamento marginal de restaurações de resina composta, através de dois sistemas de fotoativação: fonte halógena e arco de plasma de xenônio. Utilizaram-se 75 incisivos bovinos, nos quais foram confeccionadas cavidades de classe $\mathrm{V}$ na face vestibular da raiz. Após a restauração com o sistema adesivo Single Bond (3M) e a resina composta Z100 (3M), os dentes foram divididos em 5 grupos, de acordo com o método e o sistema de fotoativação: I- Elipar Trilight (fonte halógena/ fotoativação em rampa); IIOptilight Digital (fonte halógena/ fotoativação constante); III- VIP (fonte halógena/ fotoativação por pulso); IV- Apollo 95E (fonte de arco plasma/ fotoativação por passos) e VApollo 95E (fonte de arco plasma/ fotoativação constante). Após o polimento, realizaram-se 500 ciclos de termociclagem a $5^{\circ} \mathrm{C}$ e $55^{\circ} \mathrm{C}$, com banhos de imersão de 1 minuto. Os dentes foram imersos em fucsina básica a $0,5 \%$ por 4 horas e, a interface adesiva do corte que apresentou maior penetração do corante de cada dente foi analisada pelo programa de computador Image Tools. Os resultados revelaram que as resinas fotoativadas com alta intensidade de luz (grupos IV e V) apresentaram maior infiltração marginal em comparação aos demais grupos, os quais não demonstraram diferenças estatísticas entre si. Os autores concluíram que a alta intensidade de luz (fonte arco plasma de xenônio) causou maior infiltração marginal, independente do método utilizado. Os métodos de fotoativação por pulso, rampa e convencional (fontes halógenas) apresentaram graus semelhantes de infiltração marginal.

Sabendo-se que a contração de polimerização pode resultar na formação de fendas marginais, $\boldsymbol{O B I C I}$ et $\boldsymbol{a l} .^{97}$, em 2002, mediram a fenda resultante da contração de polimerização de sete resinas compostas após a fotoativação do material com diferentes técnicas. Os espécimes foram confeccionados com as resinas Alert, Surefil, P60, Z250, Z100, Definite e Flow-it e a fotoativação foi realizada de três diferentes formas: luz contínua $\left(500 \mathrm{~mW} / \mathrm{cm}^{2}\right.$ por $\left.40 \mathrm{~s}\right)$, em passos $\left(150 \mathrm{~mW} / \mathrm{cm}^{2}\right.$ por $10 \mathrm{~s}+500 \mathrm{~mW} / \mathrm{cm}^{2}$ por $\left.30 \mathrm{~s}\right) \mathrm{e}$ intermitente $\left(450 \mathrm{~mW} / \mathrm{cm}^{2}\right.$ por $\left.60 \mathrm{~s}\right)$. As fendas provenientes da contração do material foram verificadas e medidas através do MEV após 24h. Os resultados revelaram maiores fendas 
quando do emprego da luz contínua, enquanto que os outros métodos demonstraram menores fendas provenientes da contração, sem diferença significante entre eles. As resinas Z100, Definite e Flow-it mostraram as maiores fendas de contração comparadas às outras resinas. Quando a resina Z100 foi fotoativada pela técnica em passos, parece que a reação ocorreu mais lentamente, produzindo menores tensões internas e permitindo um melhor escoamento do material, o que resultou em uma contração de polimerização reduzida. Assim, os autores verificaram que a contração da resina composta depende tanto da sua composição, quanto do método de fotoativação utilizado.

$\boldsymbol{F A N}$ et $\boldsymbol{a l} .^{44}$, em 2002, investigaram a profundidade de polimerização das diferentes cores de cinco resinas compostas quando irradiadas com uma intensidade de $300 \mathrm{~mW} / \mathrm{cm}^{2}$, observando se adequava-se à recomendação da ISO (International Organization for Standardization). A ISO especifica que as resinas compostas devem apresentar uma profundidade de polimerização mínima de $1,5 \mathrm{~mm}$ quando irradiadas pelo tempo recomendado pelo fabricante, e sugerem a utilização de uma intensidade mínima de luz de $300 \mathrm{~mW} / \mathrm{cm}^{2}$, atuando em uma faixa específica de comprimento de onda (400 a 515nm). Neste trabalho, as resinas compostas foram fotoativadas pelos tempos recomendados pelos fabricantes. Os autores mediram a profundidade de polimerização através de um método descrito pela ISO e determinaram uma média das cinco amostras confeccionadas para cada cor e marca de resina composta utilizada. Os resultados mostraram que treze dos vinte e um materiais testados adequaram-se às especificações feitas pela ISO, enquanto seis dos oito materiais restantes demonstraram a profundidade de polimerização requerida somente quando o tempo de irradiação recomendado pelo fabricante foi dobrado. Os autores concluíram que $300 \mathrm{~mW} / \mathrm{cm}^{2}$ de intensidade de luz parece polimerizar efetivamente a maioria das resinas compostas, quando tempos de exposição apropriados são utilizados; no entanto, em alguns casos, necessitam ser maiores que os recomendados pelo fabricante.

Ao avaliar as principais variáveis que podem interferir no processo de fotopolimerização por luz visível, RISSI; $\boldsymbol{C A B R} \boldsymbol{A} \boldsymbol{L}^{111}$, em 2002, objetivaram alertar os profissionais para a necessidade de um constante controle clínico, observando-se tanto a técnica incremental, quanto a quantidade de energia luminosa empregada na fotoativação do material. Para isso, avaliaram a perda de energia luminosa durante a sua propagação atra vés do incremento de resina composta, considerando a cor e espessura, bem como a perda em 
função do aumento da distância da fonte de luz. Foram confeccionadas matrizes, com diâmetro de $8 \mathrm{~mm}$ e espessuras de 2, 4 e $6 \mathrm{~mm}$, com a resina composta TPH nas cores A2, B3 e $\mathrm{C} 4$, as quais foram fotoativadas por 20s. Os autores observaram que a perda de intensidade de luz, devido à propagação através da resina composta, variou em função da espessura e cor do incremento. Quanto mais espesso e saturado, menor a quantidade de luz que atravessou o incremento de resina composta, com variação na redução de intensidade de luz de 89,03\% (cor A2, com 2mm espessura) a 99,03\% (cor C4, com 6mm espessura). Pode-se verificar também que, quanto maior a distância da fonte de luz, menor a quantidade de energia luminosa que atinge a superfície do material. Os autores concluíram que vários fatores podem interferir no processo de fotopolimerização, tais como composição e espessura do material, distância da fonte de luz, orientação do feixe de raios luminosos e intensidade de luz irradiada. Assim, torna-se importante o controle clínico e observação desses fatores para a obtenção de uma adequada polimerização da resina composta.

COELHO SANTOS; SILVA E SOUZA JÚNIOR; MONDELLI', em 2002, propuseram-se, mediante uma revisão de literatura, a discutir os fatores relacionados à contração de polimerização das resinas compostas e as técnicas disponíveis para minimizar seus efeitos. Verificaram que são inúmeros os fatores responsáveis pelas tensões geradas, devendo-se considerar o módulo de elasticidade e composição da resina composta, fator de configuração cavitária e intensidade de luz emitida. Para minimizar essa contração de polimerização, os autores comentaram sobre a utilização de intensidades mais baixas de luz, com o intuito de prolongar a fase pré-gel, além do emprego da técnica de inserção incremental do material, que objetiva reduzir o fator C. Paralelamente, enfatizam a importância do lançamento de sistemas adesivos com valores mais altos de adesão e resinas compostas com novas formulações, as quais exibem menor módulo de elasticidade e conseqüente menor potencial de contração. Comentaram ainda sobre a introdução de diferentes aparelhos fotopolimerizadores no mercado, sendo que os mais recentes permitem mudanças na intensidade de luz e no tempo de exposição, favorecendo a utilização de diferentes métodos de fotoativação gradual. De acordo com vários trabalhos, observaram que a utilização da baixa, seguida da alta intensidade de luz (gradual), tem resultado em melhor adaptação marginal, aliada à manutenção das propriedades mecânicas do material. 
Para avaliar a aplicabilidade do aparelho de arco plasma, KNEZEVIC et al. ${ }^{69}$, em 2002, mediram o grau de conversão de três resinas compostas (Tetric Ceram, Pertac II e Z100), quando fotoativadas com o aparelho de arco plasma (Apollo 95E) ou com a fonte de luz halógena (Elipar Trilight). O grau de conversão foi avaliado na superfície e a $2 \mathrm{~mm}$ de profundidade. Os espécimes foram fotoativados com o arco plasma em uma intensidade de $1350 \mathrm{~mW} / \mathrm{cm}^{2}$ por $5 \mathrm{~s}$ (em passos) e, com a fonte halógena, mediante um aumento gradual da intensidade de luz $\left(200 \mathrm{~mW} / \mathrm{cm}^{2}\right.$ a $700 \mathrm{~mW} / \mathrm{cm}^{2}$ por $\left.40 \mathrm{~s}\right)$. Não houve diferença significante nos graus de conversão entre a fotoativação com o arco plasma e com a fonte de luz halógena, tanto na superfície quanto a $2 \mathrm{~mm}$ de profundidade, apesar de mostrarem-se ligeiramente menores quando da utilização do arco plasma. Um grau mais baixo de conversão foi observado na superfície e a $2 \mathrm{~mm}$ de profundidade na resina composta Z100, quando irradiada com ambas as fontes de luz, notando-se uma diminuição do grau de conversão conforme o aumento da profundidade. Os autores concluíram que o aparelho de arco plasma constitui-se uma alternativa satisfatória, pois, além de utilizar menor tempo clínico, também é capaz de proporcionar um grau de conversão quase equivalente ao obtido com as lâmpadas halógenas.

Para avaliar a efetividade de polimerização obtida com o aparelho de arco plasma comparado à fonte de luz halógena, a contração de polimerização e a microdureza de duas resinas compostas (Z100 e Tetric Ceram) foram avaliadas por PARK; KREJCI; $\boldsymbol{L U T H}^{99}$, em 2002. A contração de polimerização foi analisada após a fotoativação com o aparelho de arco plasma (Apollo 95E) por 2s (grupo 1), 3s (grupo 2), 6s (grupo 3) e 12s (grupo 4); ou com a fonte halógena quando utilizados 60s (grupo 5). Quando as resinas compostas foram fotoativadas com o arco plasma por 2 ou 3s, observourse baixa contração de polimerização comparada à fotoativação por $12 \mathrm{~s}$ ou por $60 \mathrm{~s}$ com a fonte halógena. Os autores justificaram que essa baixa contração em $2 \mathrm{~s}$ ou $3 \mathrm{~s}$ ocorre devido a uma insuficiente polimerização do material. Adicionalmente, observou-se que a Z100 mostrou contração de polimerização mais rápida que a Tetric Ceram. Para a análise da microdureza de ambas as resinas compostas, espécimes de $2 \mathrm{~mm}$ foram fotoativados por 3s, 6s ou 12s com o Apollo 95E ou com o Optilux 500 por 30 s e 60 s. Os espécimes de $3 \mathrm{~mm}$ foram fotoativados por $6 \mathrm{~s}, 12 \mathrm{~s}$ e $18 \mathrm{~s}$ com o Apollo $95 \mathrm{E}$ ou foram fotoativados convencionalmente com o Optilux 500 por 30s e 60s. Os resultados de microdureza indicaram ausência de diferenças significantes entre os grupos quando avaliada a superfície. Nas regiões mais profundas, a microdureza foi geralmente menor que a obtida na superfície, quando as resinas foram fotoativadas com o Apollo por $3 \mathrm{~s}$ 
(recomendado pelo fabricante), não se polimerizando suficientemente. Para os espécimes de $2 \mathrm{~mm}, 12 \mathrm{~s}$ de fotoativação com o Apollo foram necessários para a polimerização das regiões mais profundas da resina Tetric, enquanto que para a Z100 as superfícies mais profundas não foram polimerizadas adequadamente, apesar do tempo de exposição ter sido estendido para 12s. Para 3mm, a região profunda de ambos os materiais não foi polimerizada suficientemente, mesmo quando o tempo foi estendido para 18s. Os autores concluíram que os aparelhos de arco plasma, como o Apollo 95E, não proporcionam uma polimerização adequada das camadas mais profundas da resina composta, quando a espessura se apresenta superior a $2 \mathrm{~mm}$ e requer tempos de exposição maiores que o recomendado pelo fabricante. Para se obter vantagens com este tipo de aparelho, 12s de fotoativação são recomendados para a polimerização do material, desde que este não exceda $2 \mathrm{~mm}$ de espessura.

HILTON ${ }^{62}$, em 2002, revisou sobre o atual estágio dos estudos in vitro presentes na literatura, considerando a capacidade dos materiais restauradores e das técnicas utilizadas para a obtenção de uma adequada integridade marginal. $\mathrm{O}$ autor comentou que o vedamento na dentina constitui-se ainda um grande desafio, devido à variabilidade desse substrato. Citou que um dos maiores impactos, quando da utilização da resina composta, é a contração de polimerização observada no material, a qual pode induzir à formação de fendas marginais na interface adesiva. No entanto, fatores como o módulo de elasticidade do material restaurador e o fator de configuração cavitária influenciam na contração de polimerização e, conseqüentemente, no selamento marginal da interface. A utilização de materiais com alto módulo de elasticidade ou a presença de um alto fator $\mathrm{C}$ proporciona o desenvolvimento de maiores tensões de contração e possíveis consequiências na integridade marginal. A técnica de inserção da resina composta também exerce influência, uma vez que seu emprego minimiza os efeitos da contração. Adicionalmente, a aplicação de uma camada intermediária com um material de baixo módulo de elasticidade entre a dentina e a resina composta, como os cimentos de ionômero de vidro, e a utilização da técnica de fotoativação gradual, mostram-se efetivas na redução da infiltração marginal. A fotoativação da resina composta com baixa, seguida da alta intensidade de luz, permite uma reação de polimerização mais lenta do material, propiciando um melhor escoamento e relaxamento das tensões, enquanto que altas intensidades induzem ao aumento das fendas marginais. Segundo o autor, apesar das constantes melhorias, uma adesão confiável e duradoura dos materiais restauradores à dentina permanece ainda como um grande desafio para os pesquisadores. 
Neste mesmo ano, HILTO $N^{63}$ publicou a $2^{\text {a }}$ parte da sua revisão de literatura, enfatizando algumas variáveis referentes aos testes de adesão realizados in vitro e como estas podem afetar os resultados obtidos. O autor relatou sobre os substratos utilizados para pesquisas, tempo e condições de armazenamento dos espécimes, avaliação do velamento marginal e análise estatística. Diante da revisão realizada, comentou que a redução das tensões pode ser obtida através de um fator $\mathrm{C}$ baixo e da utilização de bases cavitárias com materiais que apresentem baixo módulo de elasticidade. Neste sentido, os cimentos de ionômero de vidro têm mostrado minimizar os índices de infiltração marginal. Ao avaliar a utilização de estresses térmicos, observou que existe grande controvérsia entre os autores, no entanto, diversos estudos empregam este método, com variação no número de ciclos. Concluiu que a grande variabilidade dentinária constitui-se ainda um dos grandes desafios a serem transpostos e que estudos laboratoriais são importantes indicadores de resultados, no entanto, não devem ser extrapolados para as situações in vivo.

Em 2002, AGUIAR; AJUDARTE; LOVADINO ${ }^{2}$ avaliaram in vitro a infiltração marginal de uma resina composta para dentes posteriores (P60), utilizando duas técnicas de inserção (incremental e única) e três técnicas de fotoativação (convencional, soft-start e distanciando-se a ponta do aparelho). Cavidades de classe $\mathrm{V}$ foram confeccionadas na superfície vestibular de 60 dentes bovinos. Os mesmos foram divididos em 6 grupos experimentais, de acordo com a técnica de inserção da resina composta e de fotoativação utilizadas: 1- incremental/ soft-start $\left(380 \mathrm{~mW} / \mathrm{cm}^{2}\right.$ por $10 \mathrm{~s}+680 \mathrm{~mW} / \mathrm{cm}^{2}$ por $\left.20 \mathrm{~s}\right)$; 2 incremental/ distância de $1,3 \mathrm{~cm}$ entre ponta ativa e resina composta $\left(200 \mathrm{~mW} / \mathrm{cm}^{2}\right.$ por $10 \mathrm{~s}+$ $680 \mathrm{~mW} / \mathrm{cm}^{2}$ por $\left.20 \mathrm{~s}\right)$; 3- incremental/ convencional $\left(680 \mathrm{~mW} / \mathrm{cm}^{2}\right.$ por $\left.30 \mathrm{~s}\right)$; nos grupos $4,5 \mathrm{e}$ 6 a resina foi inserida em um único incremento e as técnicas de fotoativação foram as mesmas utilizadas nos grupos 1, 2 e 3, respectivamente. Posteriormente, todos os espécimes foram submetidos a 3000 ciclos de ciclagem térmica nas temperaturas de $5^{\circ} \mathrm{C}$ e $55^{\circ} \mathrm{C}$, permanecendo por 1 minuto em cada temperatura. Em seguida, foram imersos no corante por 12 horas, lavados e preparados para a análise da penetração do corante. De acordo com os resultados, as três técnicas de fotoativação utilizadas não mostraram diferenças significantes quando a resina composta foi inserida de forma incremental. No entanto, nos grupos onde a inserção do material foi realizada em um único incremento, a técnica de fotoativação convencional apresentou a maior infiltração, a qual foi estatisticamente diferente das demais técnicas empregadas, as quais revelaram as menores médias de infiltração. Os grupos restaurados com 
a técnica de inserção incremental demonstraram as maiores médias de infiltração, sendo estatisticamente diferentes dos grupos restaurados com a técnica de inserção única da resina composta. Pode-se concluir que, apesar da inserção única da resina composta e da fotoativação com baixa intensidade de luz inicial resultarem em menores valores de infiltração, nenhuma técnica de fotoativação ou de inserção foi capaz de evitar a microinfiltração.

A influência do condicionamento da superfície do cimento de ionômero de vidro modificado por resina e de técnicas de inserção na infiltração marginal de restaurações de

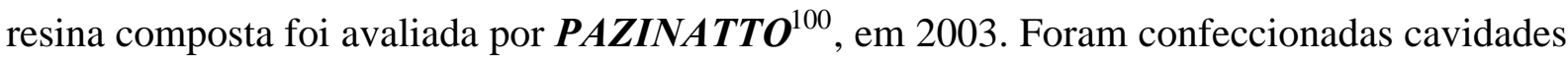
classe V em 60 dentes bovinos, com margens localizadas em dentina coronária após lixamento do esmalte. Os dentes foram divididos em seis grupos e restaurados: A Single Bond + Z250 (2 incrementos); B Single Bond + Z250 (incremento único); C- Vitrebond + condicionamento do Vitrebond + Single Bond + Z250 (2 incrementos); D- Vitrebond + condicionamento do Vitrebond + Single Bond + Z250 (incremento único); E- Vitrebond + Single Bond + Z250 (2 incrementos); F- Vitrebond + Single Bond + Z250 (incremento único). O cimento de ionômero de vidro apresentou uma espessura aproximada de $0.5 \mathrm{~mm}$ e a inserção da resina composta foi realizada com o primeiro incremento na parede incisal. Após 7 dias, as restaurações foram acabadas e polidas e, em seguida, foi realizado teste de microinfiltração marginal utilizando fucsina básica a $0.5 \%$ por $24 \mathrm{~h}$. As restaurações foram seccionadas e selecionadas as secções mais infiltradas para digitalização das imagens e determinação da penetração do corante, em milímetros, por meio do programa de computação ImageTool (UTHSCSA). A análise estatística mostrou não haver diferença na infiltração total entre os grupos C, D, E e F e entre os grupos A e B. Houve diferença significante entre os grupos de restauração mista e aqueles sem o Vitrebond. Dentro de cada grupo, houve diferença significante entre as margens incisal e cervical, exceto para o grupo F. Não houve diferença significante entre as margens incisais de todos os grupos. Na parede cervical, não houve diferença entre os grupos A, B e C; C, D, E e F; e entre B, C e D. Conclui-se que, a infiltração não foi afetada pelo condicionamento do cimento de ionômero de vidro modificado por resina, nem pela técnica de inserção da resina composta. As restaurações sanduíche (cimento de ionômero de vidro + resina composta) podem minimizar a infiltração marginal em cavidades com margens localizadas em dentina, quando comparadas às restaurações de resina composta. 


\section{3 - PROPOSIÇÃO}

Avaliar, in vitro, a infiltração marginal em cavidades de classe V confeccionadas em dentes bovinos e restauradas com resina composta, utilizando-se diferentes bases de cimento de ionômero de vidro (convencional ou modificado por resina) e diferentes técnicas de fotoativação: convencional, rampa, pulso e alta intensidade.

Este estudo tem como objetivo testar as seguintes hipóteses:

1. A utilização de bases de cimentos de ionômero de vidro (convencional e modificado por resina) diminui a infiltração marginal em restaurações de resina composta, com margens localizadas em dentina;

2. As técnicas que modulam a fotoativação minimizam a infiltração marginal em restaurações de resina composta, quando comparadas à técnica convencional;

3. A técnica de fotoativação com alta intensidade de luz aumenta a infiltração marginal, quando comparada às técnicas convencional e que modulam a potência do aparelho (rampa e pulso);

4. Não existe correlação entre o tipo de base utilizada e a técnica de fotoativação. 


\section{4 - MATERIAL E MÉTODOS}

\section{1 - Seleção dos dentes}

No presente estudo, foram utilizados 120 incisivos inferiores bovinos hígidos (Figura 1), os quais foram armazenados em solução fisiológica contendo timol a 0,1\%, imediatamente após a extração. Realizou-se a limpeza dos dentes, através de raspagem com curetas periodontais de Gracey e profilaxia com pedra-pomes e água. Posteriormente, os mesmos foram examinados para a detecção de possíveis trincas, rachaduras ou anomalias dentárias com auxílio de uma lupa binocular, que proporcionava um aumento de 10X, sendo novamente armazenados na mesma solução sob refrigeração por um período máximo de três meses.

\section{2 - Preparo cavitário}

Preparos cavitários de classe $\mathrm{V}$ foram confeccionados na face vestibular da raiz de cada dente bovino, com brocas carbide n 245 (Jet Burs KG Sorensen Indústria e Comércio Ltda), acopladas em uma turbina de alta rotação (Kavo do Brasil S.A.) sob refrigeração arágua. Cada preparo foi previamente delimitado com ponta grafite de $0,5 \mathrm{~mm}$. Todas as margens cavitárias localizaram-se em cemento/ dentina, a uma distância de $2 \mathrm{~mm}$ da junção amelo-cementária, sendo as brocas substituídas a cada cinco preparos realizados.

Todos os preparos foram executados por um único operador, utilizando uma lupa com 4X de aumento (BioArt - Indústria e Comércio) e as dimensões de cada cavidade foram medidas através do uso de paquímetro digital (Starret) e sonda milimetrada periodontal (Duflex/ SS White). As dimensões do preparo foram de 4,0mm de comprimento, por 3,0mm de largura e 1,5mm de profundidade (Figura 2). A cavidade apresentou-se com os ângulos internos arredondados, obtidos devido à extremidade arredondada da broca carbide utilizada, ausência de retenções mecânicas adicionais e ângulo cavo-superficial nítido e sem bisel (Figura 3).

Posteriormente, realizourse o acabamento dos preparos com a mesma broca, em baixa rotação (Kavo do Brasil), com movimentos suaves e intermitentes, para que calor excessivo não fosse gerado no substrato dentinário. Instrumentos cortantes manuais, como a enxada $\mathrm{n}^{0}$ 8/9 (Duflex/ SS White), foram também utilizados para a regularização da parede axial. 


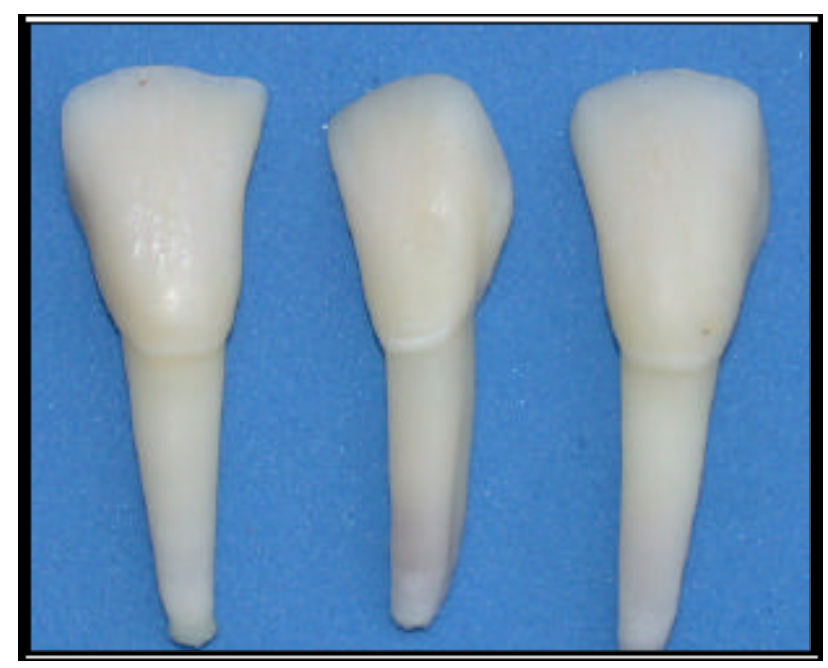

Figura 1 - Dentes incisivos inferiores bovinos selecionados para a pesquisa

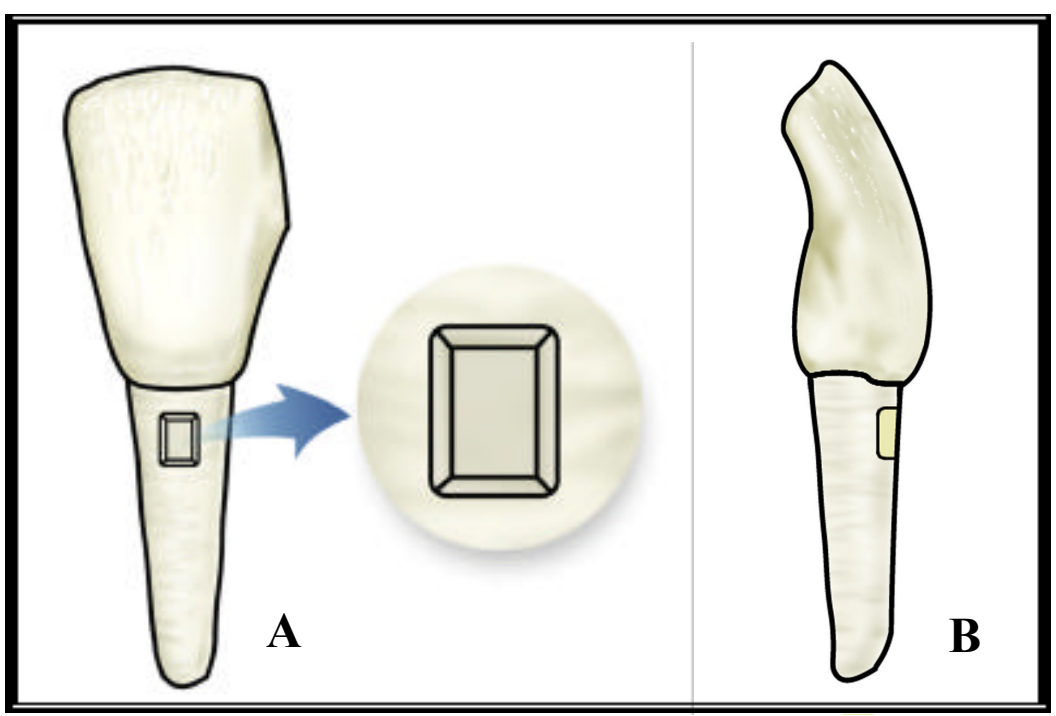

Figura 2 - Desenho esquemático das dimensões do preparo cavitário: A- 4mm X $3 \mathrm{~mm}$; B- $1,5 \mathrm{~mm}$ de profundidade

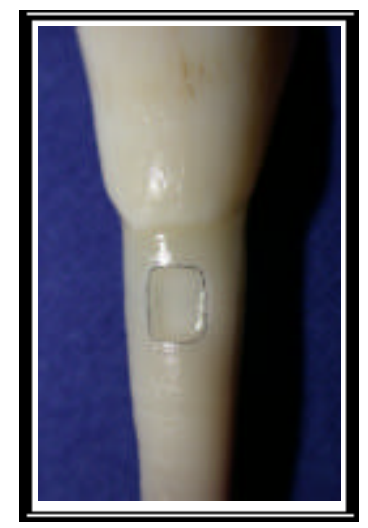

Figura 3 - Preparo cavitário 


\section{3 - Materiais e procedimentos restauradores}

\subsection{1 - Materiais}

Os 120 dentes foram aleatoriamente divididos em 12 grupos com 10 dentes cada, para que os procedimentos restauradores fossem realizados, utilizando-se diferentes técnicas de fotoativação, mediante o uso de quatro aparelhos, e diferentes bases de cimento de ionômero de vidro. Os materiais e aparelhos fotopolimerizadores utilizados na pesquisa estão apresentados na Tabela 1 e nas Figuras 4, 5 e 6.

Tabela 1 - Materiais utilizados na pesquisa

\begin{tabular}{|c|c|c|c|}
\hline MATERIAL & FABRICANTE & LOTE & VALIDADE \\
\hline Scotchbond Etchant & 3M ESPE do Brasil Ltda. & 7523 & $05 / 2004$ \\
\hline Single Bond & 3M ESPE do Brasil Ltda. & 1105 & $04 / 2004$ \\
\hline Z100 (A2) & 3M ESPE do Brasil Ltda. & 8004 & $03 / 2004$ \\
\hline Ketac Bond & 3M ESPE do Brasil Ltda. & 0104320 & $12 / 2003$ \\
\hline Vitrebond & 3M ESPE do Brasil Ltda. & 0808 & $03 / 2004$ \\
\hline
\end{tabular}

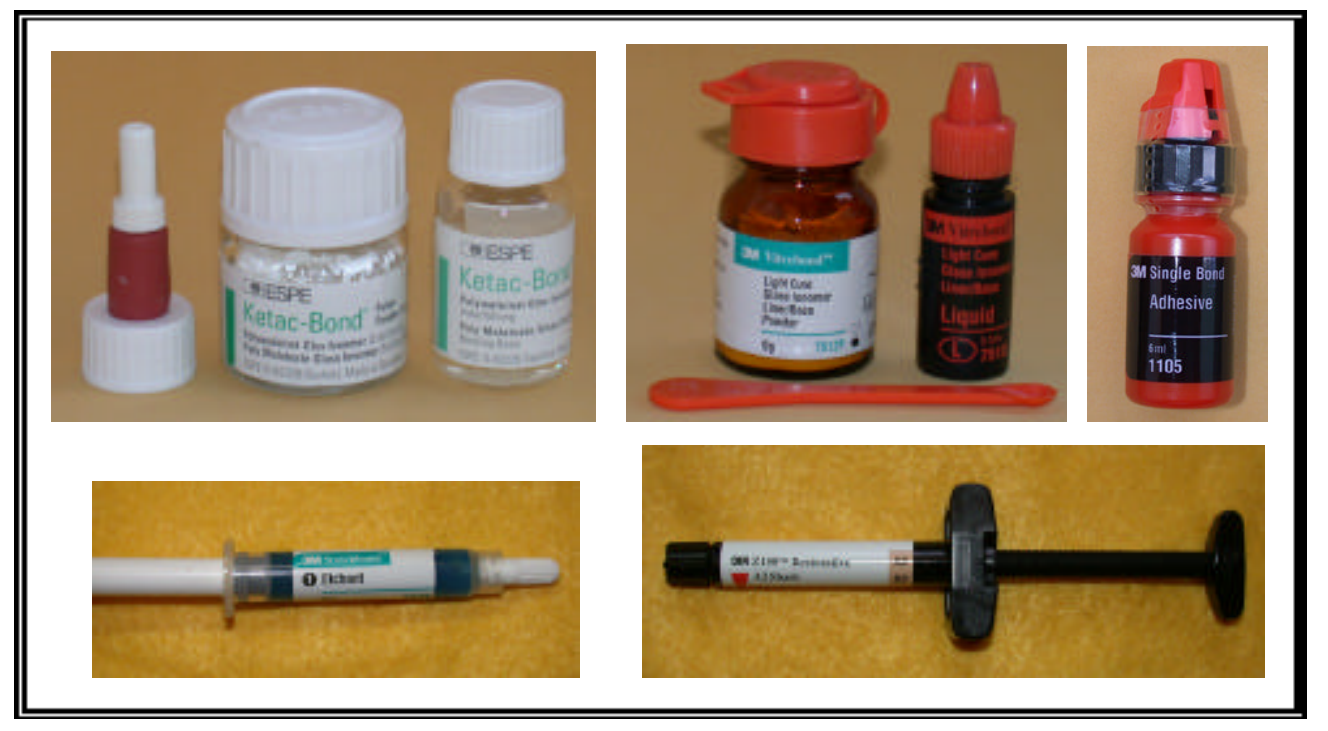

Figura 4 - Materiais utilizados no estudo 


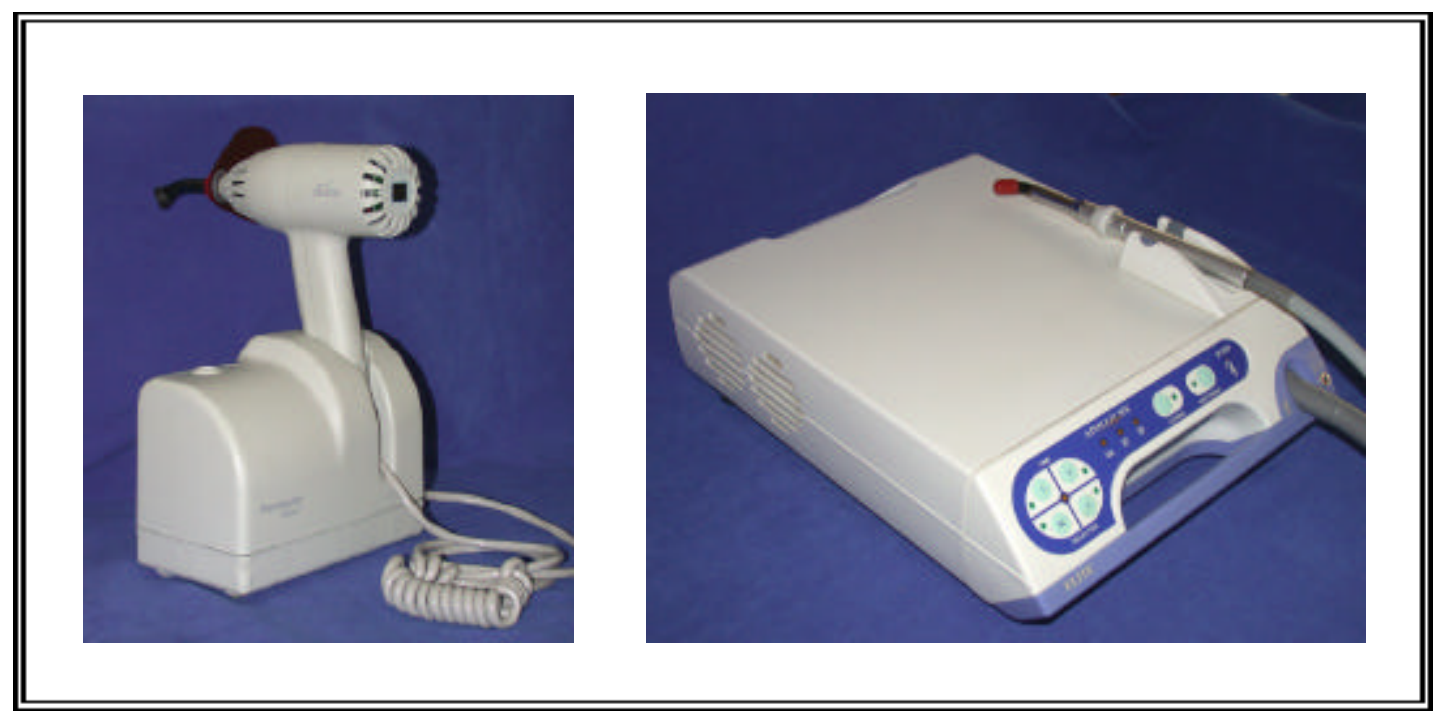

Figura 5 - Aparelhos fotopolimerizadores Optilight Digital (Gnatus) e Apollo 95E (Dental Medical Diagnostics)

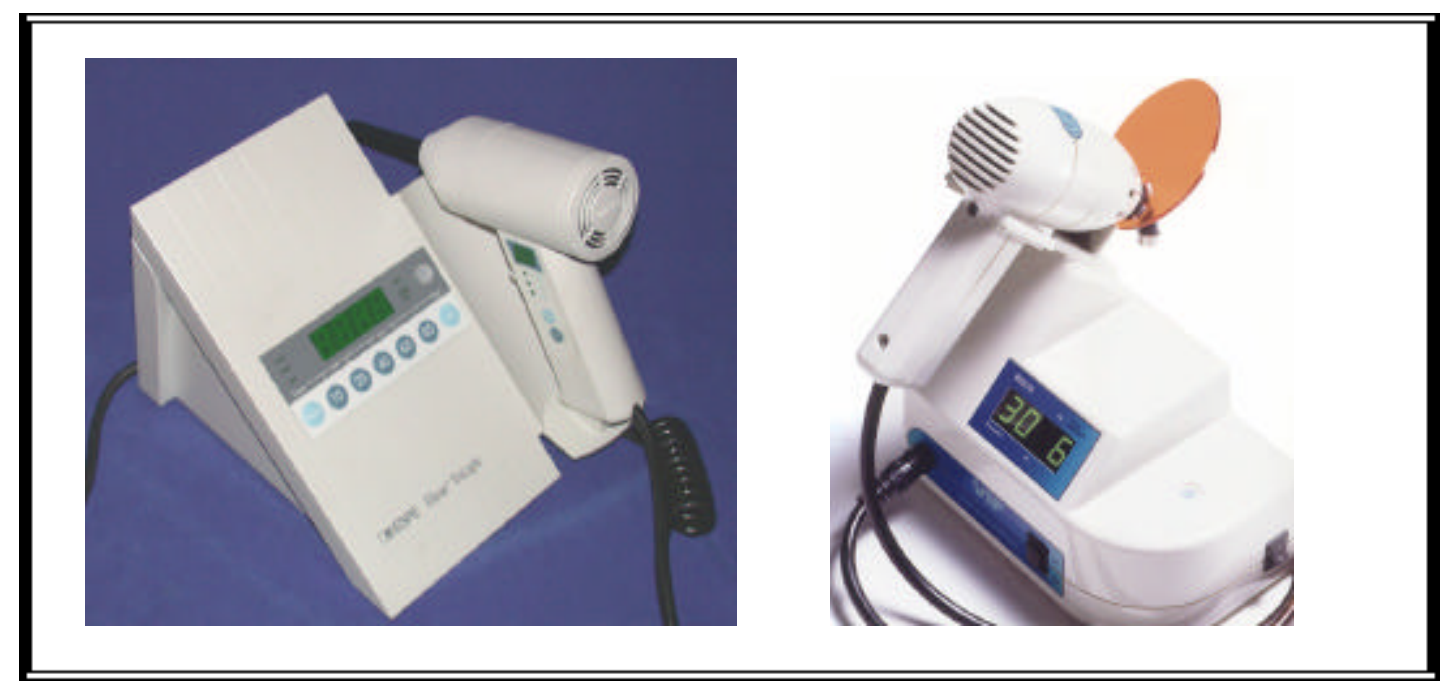

Figura 6 - Aparelhos fotopolimerizadores Elipar Trilight (ESPE) e VIP (Bisco)

\subsection{2 - Procedimentos restauradores}

Os procedimentos restauradores realizados nos doze grupos experimentais encontramse resumidos na Tabela 2 . 
Tabela 2 - Procedimentos restauradores realizados nos diferentes grupos experimentais

\begin{tabular}{|c|c|c|c|c|c|c|}
\hline GRUPO & $\begin{array}{l}\text { PRÉ-TRAT. } \\
\text { DENTINA }\end{array}$ & BASE & TRAT. DENTINA & $\begin{array}{l}\text { SISTEMA } \\
\text { ADESIVO }\end{array}$ & RESINA & FOTOATIVAÇÃO \\
\hline 1 & & & $\begin{array}{c}\text { ác. fosfórico a } 35 \% \\
-15 \mathrm{~s}\end{array}$ & Single Bond & $\mathrm{Z} 100$ & $\begin{array}{l}\text { Optilight Digital } \\
(\mathrm{n}=10)\end{array}$ \\
\hline 2 & & Vitrebond & $\begin{array}{c}\text { ác. fosfórico a } 35 \% \\
-15 \mathrm{~s}\end{array}$ & Single Bond & $\mathrm{Z} 100$ & $\begin{array}{l}\text { Optilight Digital } \\
\qquad(\mathrm{n}=10)\end{array}$ \\
\hline 3 & $\begin{array}{c}\text { Ácido } \\
\text { poliacrílico } \\
10 \mathrm{~s}\end{array}$ & Ketac Bond & $\begin{array}{l}\text { ác. fosfórico a } 35 \% \\
-15 \mathrm{~s}\end{array}$ & Single Bond & $\mathrm{Z} 100$ & $\begin{array}{l}\text { Optilight Digital } \\
\qquad(\mathrm{n}=10)\end{array}$ \\
\hline 4 & & & $\begin{array}{l}\text { ác. fosfórico a } 35 \% \\
-15 \mathrm{~s}\end{array}$ & Single Bond & $\mathrm{Z} 100$ & $\begin{array}{l}\text { Elipar Trilight } \\
\quad(\mathrm{n}=10)\end{array}$ \\
\hline 5 & & Vitrebond & $\begin{array}{c}\text { ác. fosfórico a } 35 \% \\
-15 \mathrm{~s}\end{array}$ & Single Bond & $\mathrm{Z} 100$ & $\begin{array}{l}\text { Elipar Trilight } \\
\quad(n=10)\end{array}$ \\
\hline 6 & $\begin{array}{c}\text { Ácido } \\
\text { poliacrílico } \\
10 \mathrm{~s}\end{array}$ & Ketac Bond & $\begin{array}{l}\text { ác. fosfórico a } 35 \% \\
-15 \mathrm{~s}\end{array}$ & Single Bond & $\mathrm{Z} 100$ & $\begin{array}{l}\text { Elipar Trilight } \\
\quad(\mathrm{n}=10)\end{array}$ \\
\hline 7 & & & $\begin{array}{c}\text { ác. fosfórico a } 35 \% \\
-15 \mathrm{~s}\end{array}$ & Single Bond & $\mathrm{Z} 100$ & $\operatorname{VIP}(n=10)$ \\
\hline 8 & & Vitrebond & $\begin{array}{c}\text { ác. fosfórico a } 35 \% \\
-15 \mathrm{~s}\end{array}$ & Single Bond & $\mathrm{Z} 100$ & $\operatorname{VIP}(n=10)$ \\
\hline 9 & $\begin{array}{c}\text { Ácido } \\
\text { poliacrílico } \\
10 \mathrm{~s}\end{array}$ & Ketac Bond & $\begin{array}{l}\text { ác. fosfórico a } 35 \% \\
-15 \mathrm{~s}\end{array}$ & Single Bond & $\mathrm{Z} 100$ & $\operatorname{VIP}(n=10)$ \\
\hline 10 & & & $\begin{array}{c}\text { ác. fosfórico a } 35 \% \\
-15 s\end{array}$ & Single Bond & $\mathrm{Z} 100$ & Apollo 95E $(n=10)$ \\
\hline 11 & & Vitrebond & $\begin{array}{c}\text { ác. fosfórico a } 35 \% \\
-15 \mathrm{~s}\end{array}$ & Single Bond & $\mathrm{Z} 100$ & Apollo 95E $(\mathrm{n}=10)$ \\
\hline 12 & $\begin{array}{c}\text { Ácido } \\
\text { poliacrílico } \\
10 \mathrm{~s}\end{array}$ & Ketac Bond & $\begin{array}{l}\text { ác. fosfórico a } 35 \% \\
-15 \mathrm{~s}\end{array}$ & Single Bond & $\mathrm{Z} 100$ & Apollo 95E $(n=10)$ \\
\hline
\end{tabular}

Após a realização dos preparos, as cavidades foram lavadas com jatos de ar-água e secas com suaves jatos de ar, para que não ocorresse desidratação da superfície dentinária.

\section{$>\quad$ Grupos 1, 4, 7 e 10}

Estes grupos receberam apenas resina composta como material restaurador. Inicialmente, os passos de condicionamento ácido e aplicação do sistema adesivo seguiram as instruções do fabricante com relação à forma de aplicação, ao número de camadas e ao tempo de fotoativação. Primeiramente, condicionou-se as paredes de dentina com ácido fosfórico em forma de gel e concentração de 35\% (3M ESPE), durante 15 segundos. Em seguida, as cavidades foram lavadas abundantemente com jatos de ar-água por 30 segundos e secas com papel absorvente, para que a superfície dentinária apresentasse um brilho leve e homogêneo, indicando a presença de umidade. Posteriormente, aplicourse o sistema adesivo Single Bond (3M ESPE) sobre a dentina em duas camadas consecutivas, com pincel descartável, secando- 
se, em seguida, com leve jato de ar à distância por 2 a 5 segundos, para evitar que o excesso de material acumulasse nos ângulos internos da cavidade. Após a obtenção de uma superfície brilhante e uniforme, a fotoativação foi executada com o aparelho Optilight Plus (Gnatus) por 10 segundos, em uma intensidade de $450 \mathrm{~mW} / \mathrm{cm}^{2}$ de luz. Esta intensidade foi aferida com o radiômetro Curing Radiometer Model (Demetron) previamente a sua utilização.

A resina composta selecionada foi a Z100 (3M ESPE), a qual foi inserida na cavidade pela técnica do incremento único $(1,5 \mathrm{~mm}$ de espessura) com espátula especial de titânio (Thompson Dental Co) e o acabamento imediato foi realizado com lâmina de bisturi número 15, do centro da restauração em direção às margens (Figura 7). Durante a remoção dos excessos de material restaurador, removeram-se também os excessos de adesivo que, porventura, tivessem atingido limites externos da cavidade.

\section{$>\quad$ Grupos 2, 5, 8 e 11}

Nestes grupos, foi utilizada uma base de cimento de ionômero de vidro modificado por resina sob a restauração de resina composta. A aplicação do cimento de ionômero de vidro modificado por resina (Vitrebond - 3M ESPE) foi realizada sem que a superfície dentinária fosse condicionada previamente com ácido poliacrílico, mas somente lavada com jatos de ar-água. O material foi manipulado em uma placa de papel, segundo a proporção recomendada pelo fabricante (1:1 pó/ líquido) e, em seguida, inserido na parede axial com instrumento aplicador de cimento de hidróxido de cálcio. Foi confeccionada uma base com 0,5mm de espessura, a qual foi fotoativada com o aparelho Optilight Plus (Gnatus) por 30 segundos, a uma intensidade de luz de $450 \mathrm{~mW} / \mathrm{cm}^{2}$, mantendo-se a ponta do aparelho o mais próxima possível da superfície do dente. O excesso de material que permaneceu nas paredes circundantes foi removido com brocas $n^{\circ} 245$ em baixa rotação, para propiciar uma adequada adesão dos materiais restauradores subseqüentes. A regularização do cimento de ionômero de vidro foi realizada com a mesma broca, o que permitiu uma padronização da espessura do material, além de possibilitar a obtenção de uma superfície uniforme, sobre a qual um mesmo volume de resina composta fosse aplicado para a restauração da cavidade. Após a confecção da base, as paredes cavitárias foram condicionadas com ácido fosfórico a $35 \%$ durante 15 segundos, tomando-se cuidado para que não houvesse o condicionamento do cimento de ionômero de vidro. A aplicação do agente de união (Single Bond), a inserção da resina composta (Z100) e o acabamento da restauração seguiram os mesmos 
procedimentos acima descritos, considerando-se que, nestes grupos, a resina composta apresentou 1,0mm de espessura (Figura 7), o que foi observado previamente a sua inserção, através da utilização de uma sonda milimetrada periodontal (Duflex/ SS White).

\section{$>\quad$ Grupos 3, 6, 9, 12}

Uma base de cimento de ionômero de vidro convencional foi utilizada nestes grupos, previamente à inserção da resina composta. Realizou-se, inicialmente, o condicionamento da parede axial com ácido poliacrílico a 40\% (Durelon - 3M ESPE) por 10 segundos com pincel descartável, o qual foi substituído a cada procedimento restaurador. Em seguida, a cavidade foi lavada abundantemente com jatos de ar-água por 30 segundos e seca com suaves jatos de ar. Posteriormente, foi confeccionada uma base com o cimento de ionômero de vidro convencional Ketac Bond (3M ESPE), o qual foi manipulado por 45 segundos em uma placa de papel, de acordo com a proporção recomendada pelo fabricante (1:1 pó/ líquido). O material foi inserido na parede axial, apresentando $0,5 \mathrm{~mm}$ de espessura. Aguardaram-se 5 minutos para a presa do cimento de ionômero de vidro. Os excessos de material, que permaneceram nas paredes circundantes após sua presa, foram removidos de acordo com os mesmos procedimentos descritos anteriormente. Posteriormente, a cavidade foi condicionada com ácido fosfórico a 35\% durante 15 segundos, tomando-se cuidado para que o cimento de ionômero de vidro não fosse condicionado. A aplicação do sistema adesivo dentinário (Single Bond), a inserção da resina composta (Z100) e o acabamento da restauração seguiram os mesmos procedimentos já descritos, considerando-se que, nestes grupos, a resina composta apresentou-se também com 1,0mm (Figura 7), espessura esta conferida previamente à inserção do material, com uma sonda milimetrada periodontal (Duflex/ SS White). 


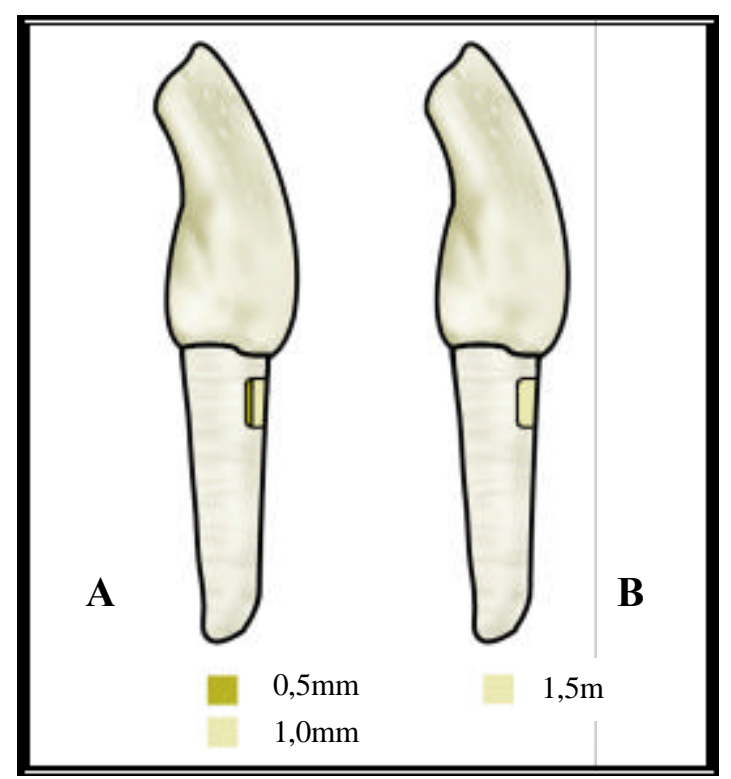

Figura 7 - Representação esquemática: A- base de cimento de ionômero de vidro/ resina composta; B- resina composta

\subsection{3 - Técnicas de fotoativação}

As restaurações de resina composta foram fotoativadas com quatro aparelhos (Optilight Digital, Elipar Trilight, VIP e Apollo 95E), os quais proporcionaram a utilização de diferentes técnicas de fotoativação do material, respectivamente: convencional, em rampa, em pulsos e com alta intensidade de luz (Tabela 3).

Convém salientar que todas as unidades fotoativadoras tiveram suas intensidades de luz medidas com o radiômetro Curing Radiometer Model (Demetron), exceto o Apollo 95E, que, por emitir alta intensidade de luz, não possibilita a medição em um radiômetro convencional. A sua intensidade de luz foi aferida no Instituto de Física de São Carlos, com o medidor de potência OPHIR OPTRONICS LTD (Jermalem, Israel).

Um estabilizador de voltagem também foi acoplado a todos os aparelhos para evitar variação e para uma melhor padronização da intensidade de luz, durante a fotoativação da resina composta. 
Tabela 3 - Técnicas de fotoativação e intensidades de luz emitidas pelos diferentes aparelhos fotopolimerizadores

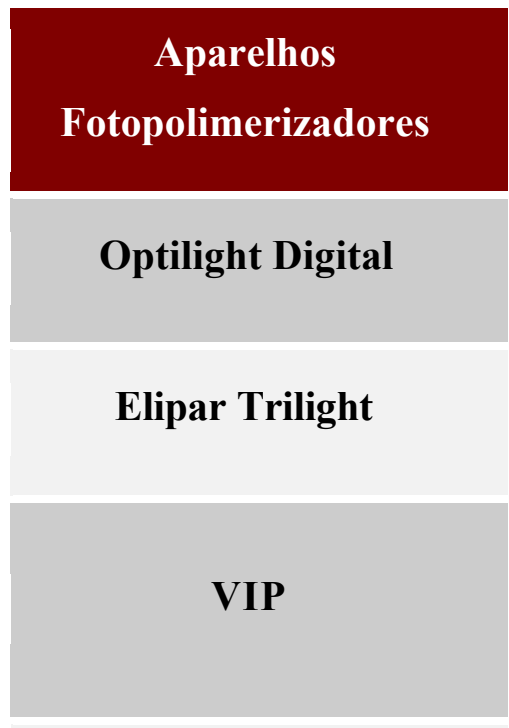

Apollo 95E

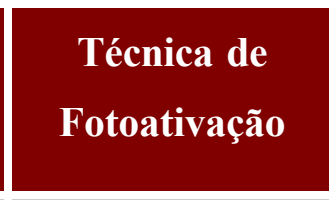

convencional

convencional

rampa

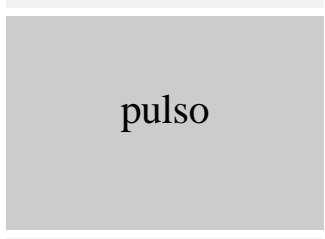

alta intensidade

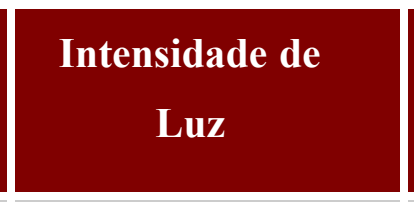

$450 \mathrm{~mW} / \mathrm{cm}^{2}$

$100 \mathrm{~mW} / \mathrm{cm}^{2} \mathrm{a}$

$800 \mathrm{~mW} / \mathrm{cm}^{2}$

$200 \mathrm{~mW} / \mathrm{cm}^{2}+3$

minutos espera +

$600 \mathrm{~mW} \mathrm{~cm}^{2}$

$1600 \mathrm{~mW} / \mathrm{cm}^{2}$

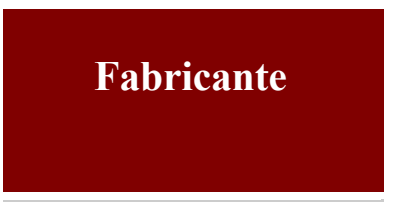

Gnatus, Ribeirão

Preto (S.P)

ESPE

Bisco Dental

Products

Dental/ Medical

Diagnostic Systems

\section{$>$ Grupos 1, 2 e 3:}

Nos três primeiros grupos, a fotopolimerização foi feita com fonte halógena (Optilight Digital - Gnatus), pela técnica de fotoativação convencional: $450 \mathrm{~mW} / \mathrm{cm}^{2}$ por 40 segundos.

\section{$>\quad$ Grupos 4, 5 e 6:}

Nestes grupos, as restaurações foram fotopolimerizadas com fonte halógena (Elipar Trilight - ESPE), utilizando a técnica de fotoativação em rampa, a qual proporcionou um aumento gradual da intensidade de luz: 100 a $800 \mathrm{~mW} / \mathrm{cm}^{2}$ durante os primeiros 15 segundos, permanecendo a $800 \mathrm{~mW} / \mathrm{cm}^{2}$ por mais 25 segundos.

\section{$>\quad$ Grupos 7, 8 e 9:}

Nesses grupos, a fotopolimerização foi realizada com fonte halógena (VIP - Bisco Variable Intensity Polymerizer), pela técnica de fotoativação por pulso: $200 \mathrm{~mW} / \mathrm{cm}^{2}$ por 3 segundos (baixa intensidade de luz), tempo de espera de 3 minutos e, em seguida, $600 \mathrm{~mW} / \mathrm{cm}^{2}$ por 30 segundos (alta intensidade de luz). 


\section{$>$ Grupos 10, 11 e 12:}

A fotopolimerização nesses grupos foi feita com fonte de arco plasma de xenônio (Apollo 95E), pela técnica de fotoativação constante (alta intensidade): $1.600 \mathrm{~mW} / \mathrm{cm}^{2}$ por 3 segundos.

Em todos os grupos experimentais, a ponta dos diferentes aparelhos fotopolimerizadores foi posicionada a uma distância bastante próxima da superfície da restauração, sendo separadas unicamente por uma tira de poliéster, para evitar que houvesse a fixação ou toque do material restaurador na extremidade, o que causaria o impedimento da completa emissão da intensidade de luz pelo aparelho ${ }^{35}$.

Após a conclusão das restaurações, os espécimes ficaram armazenados em solução fisiológica em estufa, à temperatura de $37^{\circ} \mathrm{C}$ por 06 dias, quando foram submetidos ao acabamento mediato e polimento com brocas multilaminadas (Jet Burs), discos de lixa SofLex (3M ESPE) de granulações média e fina, além das pontas de borracha abrasiva Enhance (Dentsply).

\section{4 - Ciclagem térmica e Infiltração por corante}

Após os procedimentos de acabamento e polimento, os dentes foram novamente armazenados em solução fisiológica por 24 horas para reidratação. A seguir, foram submetidos à ciclagem térmica em água destilada, em temperaturas reguladas a $5^{\circ} \mathrm{C}$ e $55^{\circ} \mathrm{C}$ (Figura 8), controladas através de um termômetro (Incoterm). Foram realizados 500 ciclos, com banhos de imersão de 1 minuto em cada temperatura, e intervalos de 5 segundos, para a transferência dos dentes. Após este procedimento, os ápices dos dentes bovinos foram vedados com cimento de ionômero de vidro Vitrebond (3M ESPE) e uma espessa camada de Super Bonder gel (LOCTITE Brasil). Em seguida, os dentes foram isolados com duas camadas de esmalte para unha de secagem rápida (Ellen Gold), exceto 1,0mm ao redor das margens das restaurações, para permitir a penetração do corante somente na interface denterestauração. Diferentes cores de esmalte de unha foram utilizadas para cada grupo de dentes, o que permitiu a diferenciação entre os mesmos (Figura 9). Durante o período de secagem do esmalte, tomou-se cuidado para o não ressecamento da estrutura dentária, colocando-se os dentes em solução fisiológica resfriada, logo após alguns minutos de desidratação. 
Após a completa secagem do esmalte de unha, os espécimes permaneceram armazenados em solução fisiológica, a temperatura ambiente, por 24 horas para reidratação, pois durante o período de aplicação do esmalte, os dentes podem sofrer desidratação, o que poderia acarretar em uma absorção excessiva de corante, alterando os resultados finais. A seguir, foram imersos em solução de fucsina básica a $0,5 \%$ em temperatura ambiente por 4 horas. Após este período, os dentes foram lavados em água corrente por 6 horas.

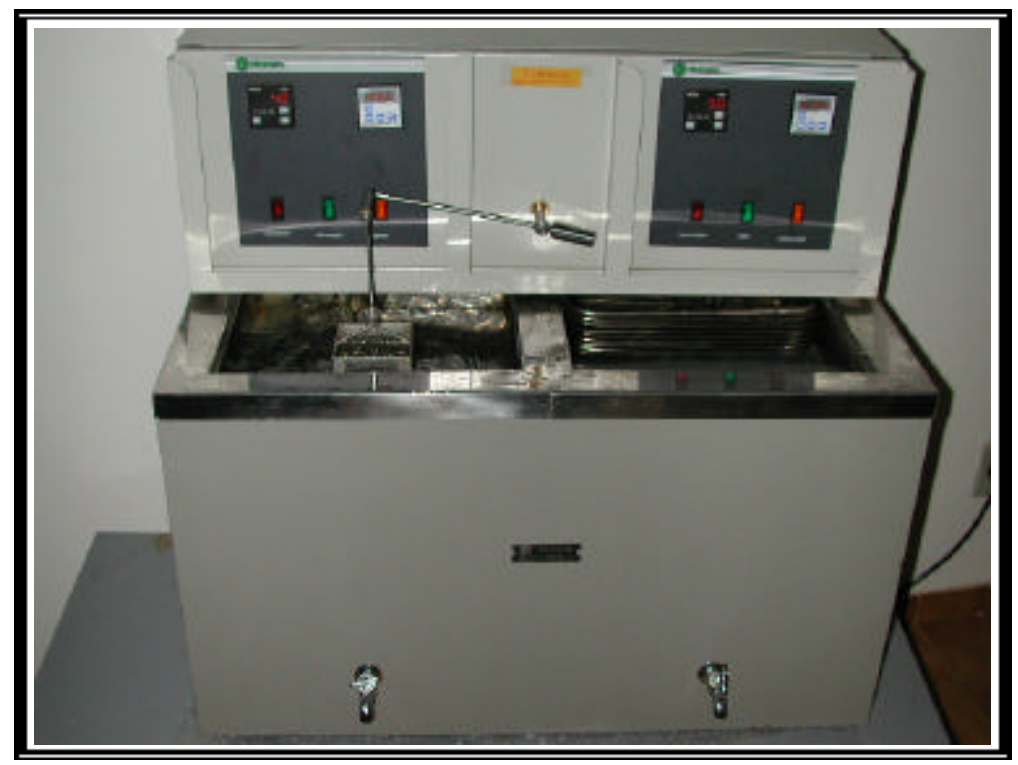

Figura 8 - Máquina utilizada para ciclagem térmica dos espécimes (Ética Equipamentos Científicos S/A)

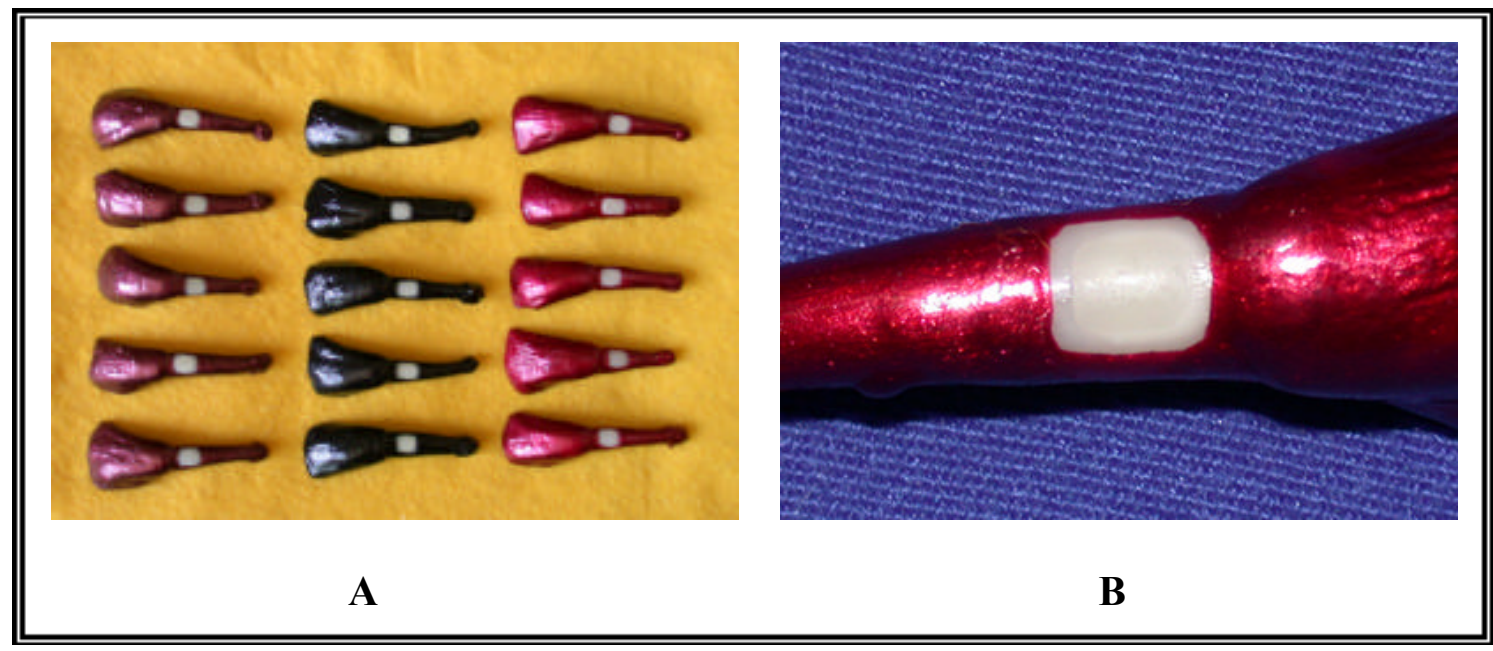

Figura 9 - Diferenciação entre os grupos experimentais (A) com exposição da interface adesiva (B) 


\section{5 - Seccionamento dos dentes}

Os espécimes foram seccionados separando-se, primeiramente, a coroa da raiz ao nível da junção amelo-cementária. Em seguida, um seccionamento transversal foi realizado, eliminando-se cerca de $2 / 3$ da raiz, com o intuito de permitir a inclusão do espécime de maneira propícia para o corte. Então, foram incluídos em resina epóxica (Resina Cristal, Redelease Ltda.) em tubos de PVC de $3 \mathrm{~cm}$ de altura e $1 / 2$ polegada de diâmetro, aguardandose 24 horas para a polimerização da mesma (Figuras 10 e 11). A escolha desta resina deveu-se à sua composição química (resapol, peroxol, pó de resina acrílica), pois quando a reação é ativada (exotérmica), pouco calor é liberado, evitando-se o superaquecimento dos corpos de prova. Um disco diamantado especial (XL12205) foi acoplado à máquina de corte (Labcut 1010, Extec) para o seccionamento longitudinal de cada um dos espécimes, obtendo-se três cortes com 0,6mm de espessura (Figura 12). Os espécimes foram devidamente identificados, segundo o grupo experimental ao qual pertenciam.

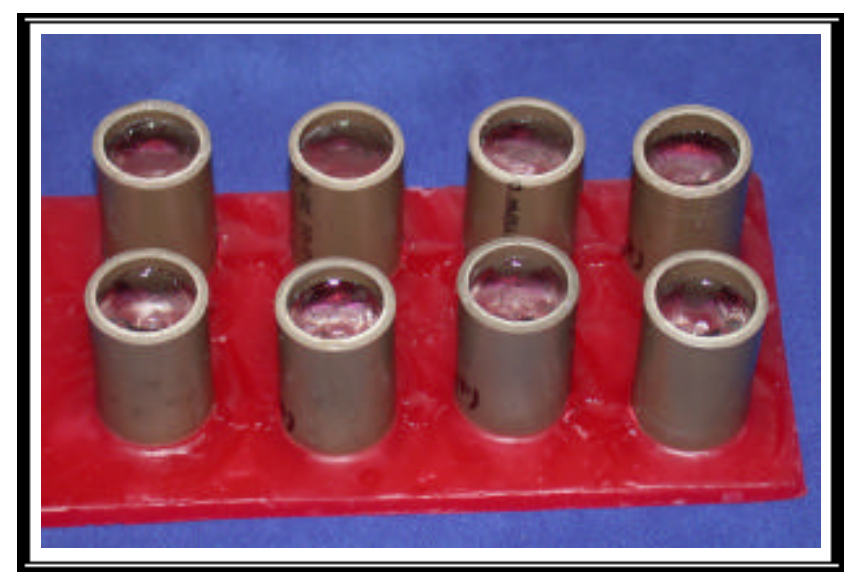

Figura 10 - Inclusão dos espécimes em tubos de PVC

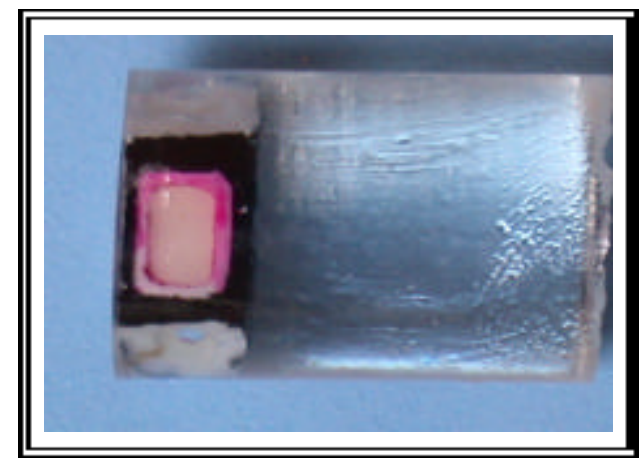

Figura 11 - Espécime incluído em resina epóxica 


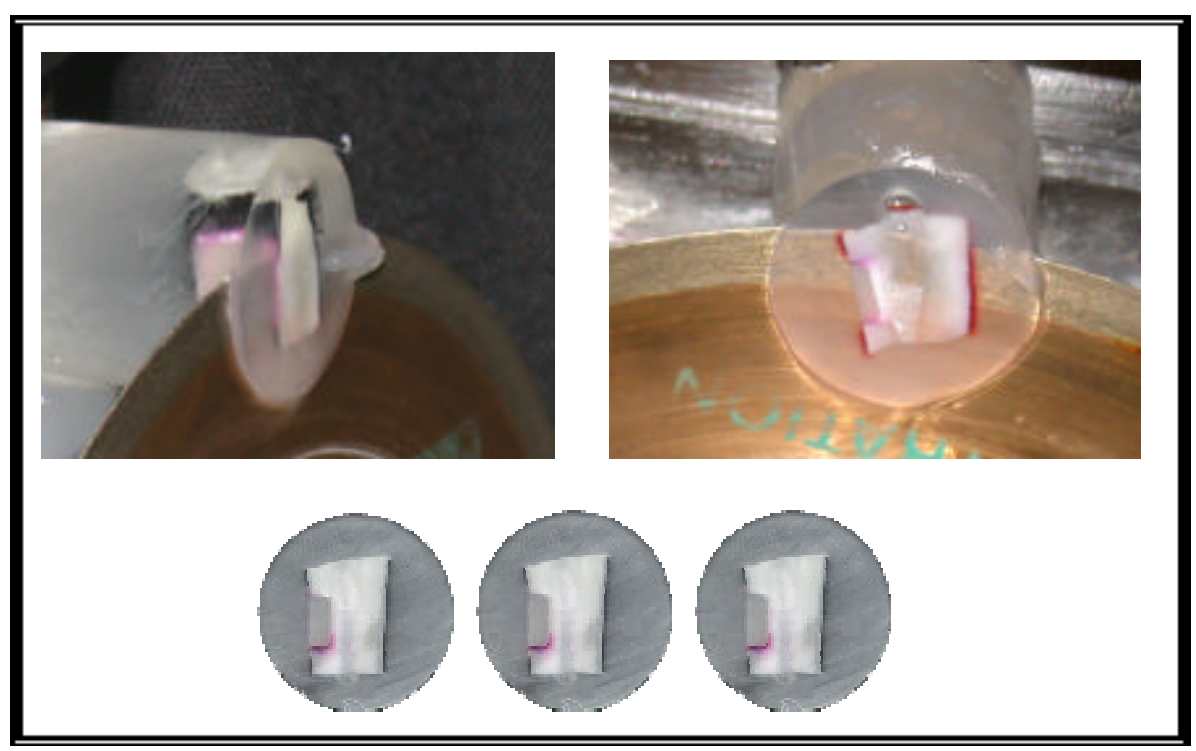

Figura 12 - Seccionamento longitudinal dos espécimes para obtenção dos cortes

\section{6 - Avaliação dos espécimes}

Para a análise da microinfiltração marginal, selecionourse o corte que apresentou maior penetração do corante na interface dente-restauração, mediante o auxílio de uma lupa binocular Optivision de 10X de aumento. Após a escolha do corte mais infiltrado de cada dente seccionado, o mesmo foi digitalizado através do uso de um scanner (Genius - HR 6 V2), com 800 dpi de resolução, para posterior análise e mensuração da extensão infiltrada pelo corante. A digitalização da imagem foi realizada juntamente com uma régua milimetrada (Figura 13), para ser feita a captura da imagem e sua transferência ao programa Adobe Photoshop. Este programa possibilitou o ajuste do brilho e contraste, diminuindo-se 15 pontos no brilho e aumentando-se 20 pontos no contraste, permitindo, assim, uma melhor visualização da área infiltrada pelo corante.

Após os ajustes citados, cada magem colorida selecionada foi transportada para o programa de computador Image Tools (UTHSCSA - University of Texas Health Science Center San Antonio), no qual um aumento de $2 \mathrm{X}$ foi realizado, para melhor visualização da extensão de infiltração. Porém, inicialmente, foi necessária fazer a calibração das dimensões obtidas. Isto foi possível devido à digitalização da régua milimetrada junto ao espécime, a qual estabeleceu uma referência de unidade de medida que é representada em pixels neste programa. Observou-se que cada 24 pixels correspondiam a 1mm, transformação esta realizada através do traçado de uma reta entre dois pontos na régua (equivalente a $1 \mathrm{~mm}$ ). 
Desta forma, foi possível padronizar a medida de infiltração de todos os espécimes. Cada espécime selecionado foi medido quatro vezes, onde as três primeiras leituras realizadas objetivaram eliminar erros. Os valores obtidos na $4^{\text {a }}$ leitura foram os considerados e submetidos à análise estatística.

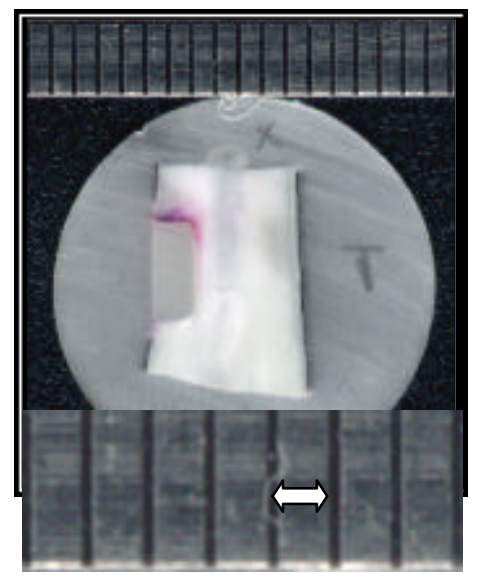

Figura 13 - Escaneamento do corte de maior infiltração, juntamente com uma régua milimetrada

Para a análise dos dados obtidos, foi empregada estatística descritiva, com uso de tabelas e parâmetros de média e desvio padrão. A comparação das médias dos grupos estudados foi realizada através da Análise de Variância (ANOVA) a dois critérios, para comparação entre base e técnica de fotoativação. Mediante as diferenças estatisticamente significantes observadas entre estes grupos analisados, utilizou-se o teste de Tukey para as comparações múltiplas.

Em todas as induções estatísticas foi adotado nível de significância de 5\%. 


\section{5 - RESULTADOS}

Os resultados referentes às medidas de infiltração marginal dos grupos experimentais estudados encontram-se listados na Tabela 4. Os valores de infiltração marginal de cada espécime estão registrados nos Anexos de 1 a 4.

Tabela 4 - Médias das infiltrações marginais (mm) e desvio padrão dos grupos experimentais em função da técnica de fotoativação e base

\begin{tabular}{|c|c|c|c|}
\hline $\begin{array}{c}\text { Técnica Fotoativação } \\
\text { (aparelho) }\end{array}$ & Grupo/Base & Média & Desvio Padrão \\
\hline & 1 Sem Base & 0,8310 & 0,6491 \\
\hline \multirow{3}{*}{$\begin{array}{c}\text { Convencional } \\
\text { (Optilight) }\end{array}$} & 2 Vitrebond & 0,3240 & 0,2587 \\
\hline & 3 Ketac Bond & 0,4040 & 0,3197 \\
\hline & 4 Sem Base & 0,6220 & 0,4928 \\
\hline \multirow[t]{3}{*}{ Rampa (Elipar) } & 5 Vitrebond & 0,2750 & 0,1864 \\
\hline & 6 Ketac Bond & 0,5770 & 0,3889 \\
\hline & 7 Sem Base & 0,9300 & 0,3871 \\
\hline \multirow[t]{3}{*}{ Pulso (VIP) } & 8 Vitrebond & 0,3630 & 0,2256 \\
\hline & 9 Ketac Bond & 0,4870 & 0,3711 \\
\hline & 10 Sem Base & 1,127 & 0,4678 \\
\hline \multirow{2}{*}{$\begin{array}{l}\text { Alta intensidade } \\
\text { (Apollo) }\end{array}$} & 11 Vitrebond & 0,9180 & 0,4247 \\
\hline & 12 Ketac Bond & 0,7630 & 0,3165 \\
\hline
\end{tabular}

Os resultados acima descritos estão também representados nas Figuras 14 e 15. 


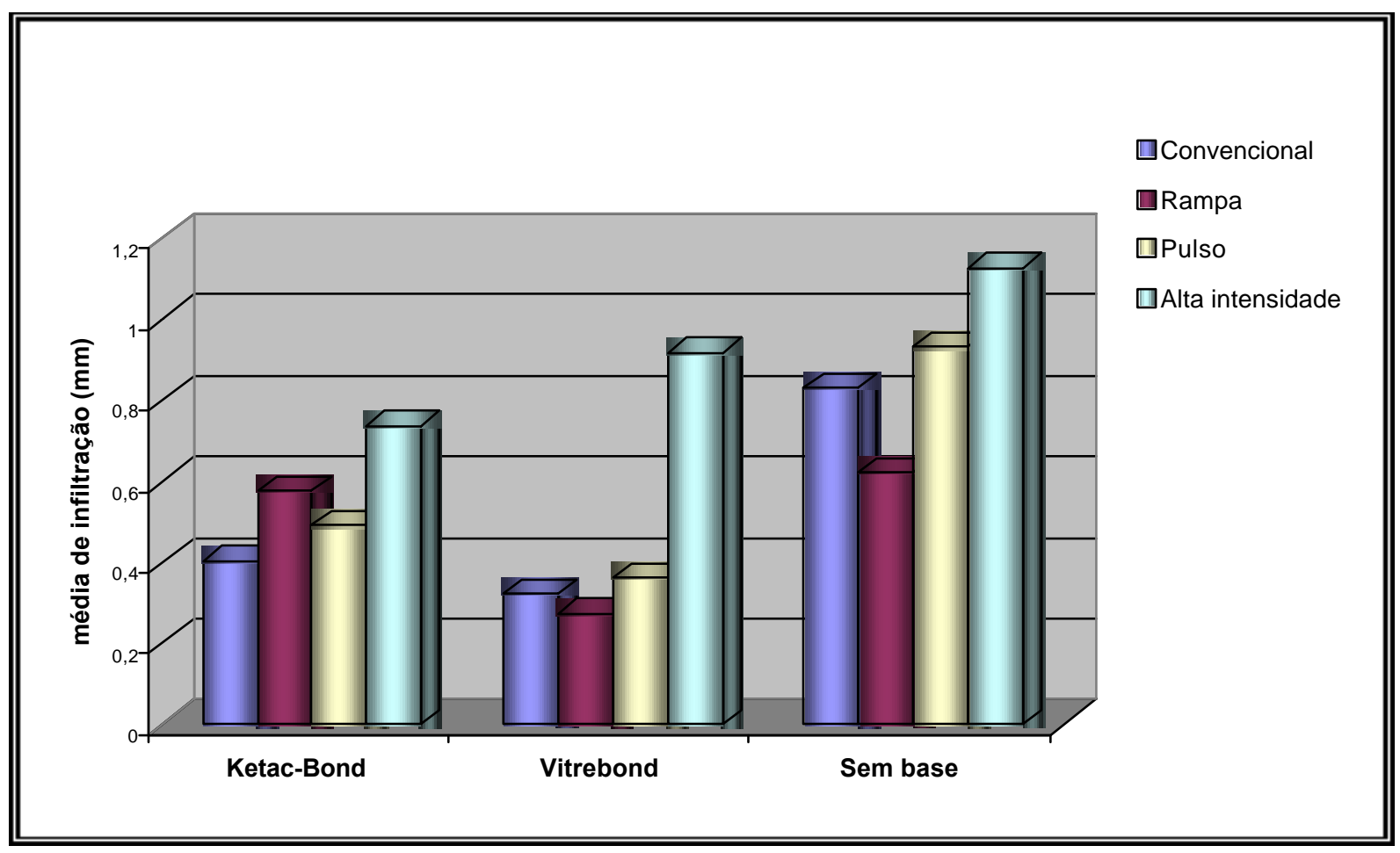

Figura 14 - Distribuição das médias de infiltração marginal (mm) das técnicas de fotoativação em função da base utilizada

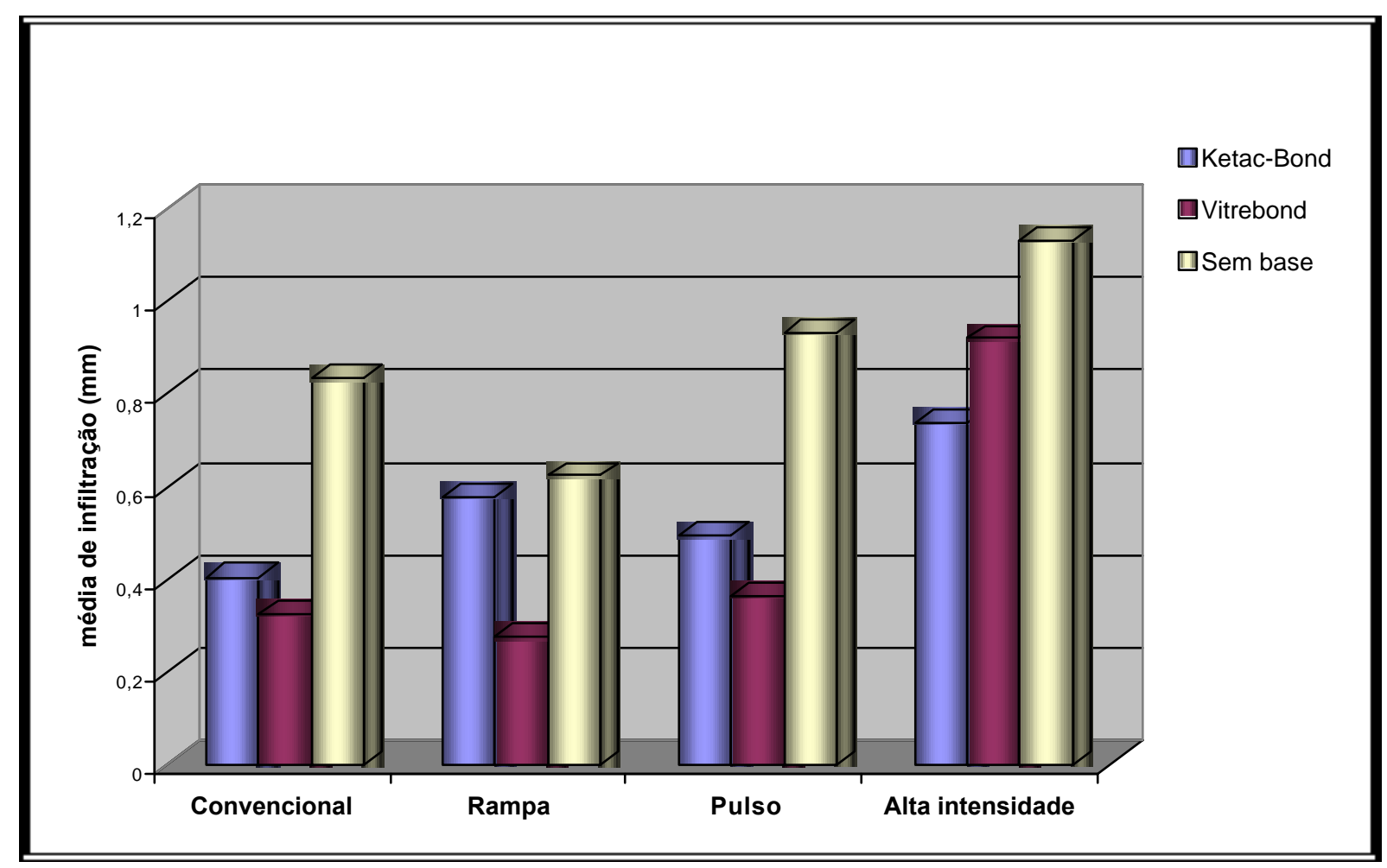

Figura 15 - Distribuição das médias de infiltração marginal (mm) das bases em função da técnica de fotoativação utilizada 
Para comparação entre as técnicas de fotoativação e materiais utilizados como base, aplicou-se a Análise de Variância (ANOVA) a dois critérios e verificoutse que houve diferença estatisticamente significante no índice de infiltração marginal das duas variáveis estudadas $(p<0,05)$. No entanto, observou-se que esses fatores são independentes, pois não mostraram interação significante entre eles (Tabela 5).

Tabela 5 - Análise de Variância a dois critérios para comparação entre técnica de fotoativação e base

\section{FONTE DE VARIAÇÃO}

Técnica de fotoativação

Base

Técnica de fotoativação X Base

* estatisticamente significante $(\mathrm{p}<0,05)$

$n s$ estatisticamente não significante

\section{F}

8,0082

11,7199

1,0734
PROBABILIDADE

$0,0000^{*}$

$0,0000^{*}$

$0,3829 n s$

Para as comparações múltiplas entre os grupos que mostraram significância estatística, utilizou-se o teste de Tukey, cujos resultados podem ser observados na Tabela 6 (técnicas de fotoativação) e na Tabela 7 (bases). Este teste revelou que os maiores valores de infiltração marginal ocorreram com a técnica de alta intensidade de luz, mostrando-se estatisticamente significantes.

Tabela 6 - Médias e desvio padrão dos valores de infiltração marginal para as técnicas de fotoativação ao nível de significância de $5 \%$

\begin{tabular}{|c|c|c|c|}
\hline Técnica fotoativação & Média $(\mathbf{m m})$ & Desvio Padrão & $\begin{array}{c}\text { Número } \\
\text { espécimes }\end{array}$ \\
\hline Convencional & 0,5197 & 0,4842 & 30 \\
\hline Rampa & 0,4957 & 0,4044 & 30 \\
\hline Pulso & 0,5933 & 0,4078 & 30 \\
\hline Alta intensidade & 0,9360 & 0,4219 & 30 \\
\hline
\end{tabular}

Grupos unidos pela barra vertical não apresentam diferenças estatisticamente significantes entre si. 
A Tabela 7 revela que diferenças não foram observadas entre as duas bases de cimento de ionômero de vidro utilizadas, porém a ausência das mesmas demonstra maiores valores de infiltração marginal.

Tabela 7 - Médias e desvio padrão dos valores de infiltração marginal para as bases de cimento de ionômero de vidro ao nível de significância de 5\%

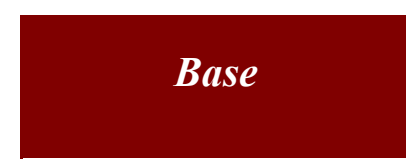

\section{Ketac Bond}

Vitrebond

Sem base

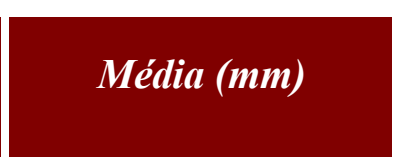

0,5610
0,4700

0,8775

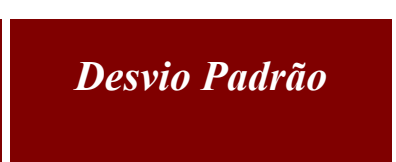

$$
0,3682
$$$$
0,3827
$$

0,5218

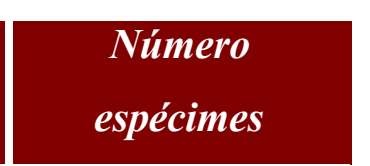

40 40

40

Grupos unidos pela barra vertical não apresentam diferenças estatisticamente significantes entre si. 


\section{6 - DISCUSSÃO}

\section{1 - Análise da Metodologia}

Os testes laboratoriais passaram a adquirir relevância, pois, com o surgimento de novos materiais e técnicas restauradoras, buscam tornar o procedimento restaurador mais eficaz. O perfeito vedamento na interface adesiva de restaurações de resina composta ainda representa um dos principais objetivos a serem alcançados e tem sido motivo dos diversos estudos de microinfiltração realizados in vitro ${ }^{16,25,46,51,52,57,75,85,106,134,146,154,157}$. Desta forma, os testes de infiltração marginal têm sido amplamente empregados e analisados pela facilidade de execução e por apresentarem resultados rápidos, no entanto, alguns aspectos devem ser discutidos e elucidados.

Apesar da maioria dos trabalhos utilizar dentes humanos, a substituição desses pelos dentes bovinos tem sido sugerida para os estudos laboratoriais ${ }^{30,94,95,108}$, devido à dificuldade na obtenção de dentes humanos extraídos, principalmente hígidos, além dos recentes problemas de ordem ética ${ }^{20}$. Assim, a possível substituição do substrato humano tornou relevante a utilização dos dentes bovinos em diferentes pesquisas que avaliam a infiltração e a adaptação marginal, 2,5,17,38,67,106,108,148,157. Vantagens como a menor probabilidade de transmissão de infecções ${ }^{17,20}$ e a possibilidade de avaliar prontamente maiores quantidades de espécimes $^{17,108,123}$, fizeram com que se optasse pela utilização de incisivos inferiores bovinos no presente estudo. Além disso, os dentes bovinos apresentam maior padronização quanto à permeabilidade, com baixa variabilidade quando comparada à dentina humana ${ }^{123}$.

A localização das margens cavitárias é outra variável nos testes de microinfiltração, podendo ser em esmalte, dentina ou em esmalte/ dentina ${ }^{109}$. No entanto, várias pesquisas mostram maior propensão à infiltração marginal nas margens localizadas em dentina $^{7,105,128,134,140}$, principalmente devido à dificuldade de obtenção de uma adequada adesão micromecânica nesse substrato ${ }^{22,143}$. Desta forma, optoutse pela realização de cavidades classe $\mathrm{V}$ na face vestibular da raiz dos dentes bovinos, considerando também que a superfície dentinária geralmente não apresenta inconvenientes, tais como rachaduras naturais, áreas de hipocalcificação, hipoplasia ou abrasão ${ }^{56}$, os quais são encontrados na superfície do esmalte.

O formato da cavidade também exerce influência na adaptação do material às paredes cavitárias $^{107,143}$, devido, principalmente, às variações na tensão proveniente da contração, as quais estão relacionadas tanto ao fator de configuração cavitária (fator C), quanto à 
capacidade de escoamento do material durante a reação de polimerização ${ }^{143}$. Para demonstrar as limitações da resina composta, cavidades tipo caixa foram confeccionadas por apresentarem alto fator $\mathrm{C}^{23}$, o que limitaria o escoamento e a liberação das tensões geradas durante a contração de polimerização.

Teoricamente, a técnica de inserção incremental da resina na cavidade minimiza os efeitos da contração ${ }^{29}$ e os índices de infiltração marginal ${ }^{154}$, pois reduz o fator de configuração cavitária, em virtude da união de cada incremento se restringir a poucas paredes ${ }^{80,85,159}$. Alguns trabalhos relataram redução da infiltração marginal com a utilização da técnica incrementap ${ }^{5,80,84,154}$, enquanto outros não encontraram diferença significante entre as técnicas de inserção incremental e única com relação à microinfiltração $4,31,78,100,106,125$.

Quando a resina composta é inserida em uma cavidade tipo caixa, através da técnica de incremento único, a competição entre as tensões de contração provenientes da polimerização e a adesão estrutura dentária-resina composta é maximizada ${ }^{37}$. No presente estudo, optou-se pela inserção da resina composta em um único incremento para que condições limites de estresse fossem proporcionadas, verificando-se a influência das técnicas de fotoativação, com diferentes intensidades de luz e, das bases de cimento de ionômero de vidro, nos resultados de infiltração marginal. Além disso, em situações experimentais, a técnica de inserção única do material pode ser utilizada para eliminar variações causadas pela aplicação de dois ou mais incrementos, onde o controle do volume de material é dificultado $^{143}$. Uma única camada de resina composta, seguida de uma única fotoativação, aumenta a possibilidade no aparecimento de fendas marginais ${ }^{143}$, sendo empregada, no presente estudo, para demonstrar as limitações do material em questão, em cavidades com alto fator $\mathrm{C}$.

A ciclagem térmica também é um procedimento comum nos estudos que avaliam microinfiltração e adaptação marginal ${ }^{4,5,16,75,76,79,106,107}$. A transferência dos espécimes de uma solução quente para outra fria é um procedimento realizado in vitro, que objetiva simular as condições in vivo, tornando o teste mais confiável ${ }^{48}$. A presença de diferentes temperaturas nas margens da restauração pode gerar tensões na interface adesiva, devido a diferenças nos coeficientes de expansão térmica entre os materiais restauradores e a estrutura dentária, podendo causar o aparecimento de fendas e a conseqüente infiltração marginal ${ }^{63,68,106,109,110}$.

Alguns estudos têm investigado os efeitos da variação de temperatura, o número de ciclos e o tempo de imersão em cada banho ${ }^{3,68,142}$, não havendo uma padronização entre eles. As temperaturas podem variar de $0^{\circ} \mathrm{C}$ a $68^{\circ} \mathrm{C}$; o tempo de imersão de poucos segundos a horas 
e o número de ciclos térmicos de 1 a $5.000^{68,126}$, embora alguns trabalhos utilizem maiores quantidades ${ }^{63}$. RETIEF $^{109}$ recomenda que os dentes restaurados sejam termociclados em banhos com temperaturas entre $8^{\circ} \mathrm{C}$ e $50^{\circ} \mathrm{C}$, completando 500 ciclos para a padronização dos testes. Afirmou que os tempos de imersão em cada banho podem variar de 15 segundos a 2 minutos, contudo, imersões por tempos maiores que 15 segundos não são recomendadas, por não serem suportáveis intraoralmente ${ }^{109}$.

Existem ainda opiniões controversas quanto à utilização da termociclagem e seus possíveis efeitos na manutenção da interface adesiva. Alguns autores observaram aumento significante da infiltração marginal em restaurações de resina composta submetidas à ciclagem térmica $^{10,77,124}$, enquanto outros relataram que a tensão térmica não acarretou em um aumento da microinfiltração, quando comparada a espécimes não termociclados ${ }^{67,133,149,153}$.

ROSSOMANDO, WENDT Jr. ${ }^{112}$, em 1995, verificaram que a infiltração marginal em restaurações submetidas à ciclagem térmica não diferiu dos espécimes não termociclados. Entretanto, observaram que a extensão de infiltração foi maior com o aumento no tempo de imersão nos banhos (60s), o que significa que a maior duração do estresse térmico desencadeia as variações volumétricas, favorecendo a penetração do corante. Assim, o potencial de infiltração é aumentado com um desafio térmico mais prolongado. Estes autores comentaram ainda que, apesar das resinas compostas apresentarem um coeficiente de expansão térmica maior que o das estruturas dentárias, a condutibilidade térmica é baixa. Desta forma, o tempo que este material fica exposto às temperaturas extremas é muito importante. Por este motivo, os espécimes permaneceram imersos por 60 segundos nas diferentes temperaturas, tempo suficiente para proporcionar alterações volumétricas nos materiais.

Diante da controvérsia entre os trabalhos sobre a aplicação ou não da ciclagem térmica, realizou-se a mesma no sentido de se estabelecer um desafio térmico na interface dente-restauração. Assim sendo, os dentes foram submetidos a 500 ciclos ${ }^{42,65,80,88,93}$,com imersão de 60 segundos em cada banho ${ }^{2,5,11,16,17,18,65,80,83,106,144}$, nas temperaturas de $5^{\circ} \mathrm{C}$ e $55^{\circ} \mathrm{C}^{5,16,42,52,65,75,76,79,80,83,85,88,93,125,146}$, possibilitando a comparação com outros trabalhos relatados na literatura. Mesmo diante da argumentação que o tempo de imersão nos banhos em testes laboratoriais não equivale à realidade clínica, a utilização de um tempo de 60 segundos em cada temperatura, neste estudo, objetivou impor condições para que diferenças de comportamento entre dente e material restaurador fossem realmente evidenciadas. 
A infiltração marginal pode ser detectada através de diversas técnicas, tais como a utilização de corantes, o uso do ar pressurizado, bactérias, radioisótopos, análise por ativação de nêutrons, produção de cáries artificiais, verificação da qualidade das margens em microscopia eletrônica de varredura, demarcadores químicos, ciclagem térmica e/ou mecânica ${ }^{3,11,68,128,142}$. A utilização de corantes é o método mais empregado por ser sensível, simples, de baixo custo e que padroniza a interpretação dos resultados ${ }^{134,142}$, os quais são determinados após o seccionamento dos espécimes ${ }^{3,126,140,149,154}$. Assim, foi escolhida para este estudo a análise da infiltração por corante após a ciclagem térmica ${ }^{107}$. A solução de fucsina básica a $0,5 \%$ foi selecionada pela facilidade de manipulação, baixo peso molecular ${ }^{63}$ e pela grande utilização e divulgação na literatura ${ }^{31,32,52,53,66,80,107,128,140,144,153,154}$, além de ser considerado um método eficiente e viável, por apresentar um contraste adequado e permitir uma avaliação direta da infiltração marginal na interface adesiva. Apesar dos espécimes geralmente serem imersos neste corante por 24 horas $^{31,53,63,66,80,100,107,133}$, em dente bovino este período não deve ultrapassar 4 horas $^{5,17}$, devido a sua maior permeabilidade e consequiente maior probabilidade de infiltração do corante em áreas desnecessárias, dificultando a interpretação dos resultados.

Para a análise da infiltração do corante, três cortes de $0,6 \mathrm{~mm}$ de espessura cada foram obtidos a partir do seccionamento no sentido longitudinal das raízes dentárias bovinas. Contudo, um questionamento existe sobre a escolha do corte a ser empregado na análise da infiltração marginal. DÉJOU; SINDRES; CAMPS ${ }^{39}$ (1996) consideraram um critério válido a análise do corte de maior infiltração do corante pela interface adesiva; metodologia essa também utilizada neste estudo e por outros autores ${ }^{25,140,149,154}$.

O método de avaliação também gera discussão, pois a análise da infiltração pode ser feita de maneira quantitativa ou qualitativa. Enquanto o método qualitativo estabelece escores para os graus de infiltração, o quantitativo constitui-se da medição linear ou da área da infiltração ${ }^{149}$. O estabelecimento de escores está sujeito à subjetividade dos examinadores, não havendo precisão nos resultados, porém grande parte dos recentes trabalhos analisa a penetração do corante dessa forma ${ }^{5,16,75,79,125,137}$. Neste estudo, foi utilizado o método quantitativo, sendo que a medição foi realizada através do programa de computador Image Tools (UTHSCSA - University of Texas Health Science Center San Antonio) ${ }^{85,140,149,154}$, o qual determina os níveis de penetração do corante por extensão ${ }^{154}$ ou área ${ }^{140}$. Sendo assim, a extensão linear da infiltração pelo corante foi medida em milímetros, somente ao longo da 
interface dente-restauração (Figura 13); critério este adotado para evitar que outras possíveis áreas atingidas pelo corante não comprometessem a interpretação dos resultados obtidos.

O sucesso das restaurações de resina composta e, conseqüentemente, a menor probabilidade de infiltração marginal, pode estar diretamente relacionada ao grau de conversão do material. Assim, a crescente utilização das resinas compostas na Dentística Restauradora requer um profundo entendimento sobre o mecanismo básico da sua reação de polimerização, bem como dos fatores que podem interferir neste processo ${ }^{35}$.

Para que a reação de polimerização da resina composta se inicie é importante que o iniciador nela presente, geralmente a canforoquinona ${ }^{35,60,138}$, absorva energia dentro de um comprimento de onda específico, compreendido entre 450 a 500nm, com pico de absorção em $470 \mathrm{~nm}^{19,35,60,113}$. A exposição à luz fará com que a energia emitida (fótons) seja absorvida pela molécula de canforoquinona, a qual será levada a um estado energético mais elevado, considerado seu estado de excitação $0^{24,113}$. É neste momento que a canforoquinona reage com a amina, resultando na formação de um radical livre, molécula extremamente reativa e com um elétron livre, o qual irá formar uma ligação covalente. Em sequiência, esse radical livre reagirá com o monômero, possuidor de uma ligação dupla de carbono $(\mathrm{C}=\mathrm{C})$, que iniciará a reação de polimerização da resina composta. Desta forma, inicia-se a reação em cadeia com a conversão das ligações duplas de carbono para ligações simples covalentes ${ }^{24,113}$.

De acordo com RUEGGEBERG et al. ${ }^{116}$ (1994), os fatores que mais influenciam o grau de polimerização da resina, ou seja, a adequada conversão dos monômeros em polímeros, são a intensidade de luz $z^{24,46,141}$, o tempo de exposição à luz $z^{24,46,141}$ e a espessura do incremento de resina ${ }^{141}$, os quais encontram-se sob o controle do profissional.

A intensidade de luz ou densidade de potência $\left(\mathrm{mW} / \mathrm{cm}^{2}\right)^{19,141}$, emitida pelos aparelhos fotopolimerizadores, tem sido considerada um dos fatores de grande importância para a reação de polimerização das resinas $\operatorname{compostas}^{113}$, pois uma variação dos valores da intensidade pode alterar de forma significante o grau de polimerização dos compósitos, causando deficiência na adaptação marginal ${ }^{70,148}$, além da possibilidade de modificação de algumas propriedades do material ${ }^{148}$.

Atualmente, diferentes densidades de potência, a partir de $350 \mathrm{~mW} / \mathrm{cm}^{2}$ até maiores que $1000 \mathrm{~mW} / \mathrm{cm}^{2}$, podem ser encontradas entre os aparelhos à base de luz halógena, arco plasma, laser ou $\operatorname{LED}^{19,35,60,136}$. No presente estudo, optoutse pela utilização de diferentes aparelhos (três fontes halógenas e uma de arco plasma), por emitirem intensidades de luz 
variadas, possibilitando a análise da real influência dessas variações no vedamento marginal das restaurações de resina composta em cavidades de classe V.

Intensidades máximas de luz, compreendidas em $450 \mathrm{~mW} / \mathrm{cm}^{2}, 600 \mathrm{~mW} / \mathrm{cm}^{2}$, $800 \mathrm{~mW} / \mathrm{cm}^{2}$ e $1.600 \mathrm{~mW} / \mathrm{cm}^{2}$ foram utilizadas nas técnicas convencional, pulso, rampa e alta intensidade, respectivamente. Teoricamente, essas intensidades mostraram-se adequadas, uma vez que RUEGGEBERG; CAUGHMAN; CURTIS ${ }^{114}$ (1994) recomendaram $400 \mathrm{~mW} / \mathrm{cm}^{2}$ para a polimerização de $2 \mathrm{~mm}$ de resina composta. FAN et al. ${ }^{44}$ (2002) afirmaram que $300 \mathrm{~mW} / \mathrm{cm}^{2}$ de intensidade de luz é capaz de polimerizar efetivamente várias cores de resina composta, com 1,5mm de profundidade, dentro dos tempos de exposição recomendados pelos fabricantes. Contudo, deve ser enfatizado que os aparelhos que apresentam valores inferiores a $280 \mathrm{~mW} / \mathrm{cm}^{2}$ necessitam de manutenção técnica, não devendo ser utilizados ${ }^{24}$.

Considerando que as intensidades de luz emitidas pelos diferentes aparelhos fotopolimerizadores são de suma importância para o processo de polimerização do material $^{24,113,127,141}$, as mesmas foram aferidas, no presente estudo, com um radiômetro (Demetron Curing Radiometer) antes da sua utilização, a fim de proporcionarem intensidades adequadas e desejadas para cada técnica a ser testada ${ }^{57,157}$. Este radiômetro somente pode ser utilizado para aparelhos que emitem até $1.000 \mathrm{~mW} / \mathrm{cm}^{2}$, o que proporcionou a medição das três fontes halógenas utilizadas, porém não do Apollo 95E, por irradiar $1.600 \mathrm{~mW} / \mathrm{cm}^{2}$, o qual foi aferido no laboratório de física da Universidade de São Carlos.

Para padronizar a energia irradiada e evitar variações na conversão da resina composta, a ponta ativa da fonte de luz permaneceu o mais próxima possível da superfície da resina, como recomendado por DAVIDSON; DE GEE $^{35}$ (2000) e SHORTALL; HARRINGTON; WILSON ${ }^{127}$ (1995), propiciando a análise da influência das diferentes intensidades utilizadas em cada grupo, nos resultados finais de infiltração. A opção por diferentes aparelhos facilitou o emprego das quatro técnicas de fotoativação, com diferentes intensidades de luz, possibilitando a padronização da intensidade nos 30 espécimes de cada grupo experimental.

Fatores como alteração de voltagem, degradação do bulbo da lâmpada ou do filtro, fratura de filamentos da fibra óptica flexível, contaminação por restos de resina composta na ponta do aparelho e quebra dos componentes deste aparelho ${ }^{35,127}$, também podem causar variações na intensidade de luz, devendo ser cuidadosamente analisados para que ocorra adequada polimerização do material ${ }^{141}$. 
Desta forma, todos esses critérios mencionados foram rigorosamente averiguados e seguidos, pois uma adequada intensidade de luz é requerida, para que a polimerização ocorresse de forma padronizada em toda a extensão do materia ${ }^{44,84}$.

$\mathrm{Na}$ verdade, não existe um consenso a respeito dos valores exatos de intensidade de luz para uma adequada polimerização das resinas compostas. Assim, o tempo de exposição assume papel importante à medida que se inter-relaciona com a intensidade de luz, de tal forma que torna impossível estabelecerem-se parâmetros para um, sem considerar o outro ${ }^{111}$.

A intensidade de luz, o tempo de exposição e a espessura da resina composta são fatores que podem ser controlados pelo profissional ${ }^{24}$ e considerados importantes para a obtenção de uma adequada reação de polimerização e melhores características do material, o que propicia um melhor vedamento marginal.

O tipo e tamanho das partículas de carga, bem como a quantidade e tipo de pigmentos, são também muito importantes para a determinação do grau de polimerização do material $^{111,116}$. Autores como CHRISTENSEN et al. ${ }^{27}$ (1999) constataram que a formulação das resinas compostas foi o fator predominante no resultado da contração de polimerização e geração de tensões, quando da utilização de diferentes técnicas de fotoativação (rampa, pulso e convencional) com variadas fontes de luz (halógena, arco de plasma de xenônio e laser de argônio).

A resina composta Z100 (3M ESPE), a qual foi selecionada para este estudo, é um compósito formulado com carga híbrida, constituída de partículas de zircônio-sílica, com maior dureza devido aos vidros cerâmicos e à maior quantidade de carga ${ }^{29}$. Segundo o fabricante, o elevado número de duplas ligações por unidade de peso proporciona um alto grau de ligações cruzadas, que se traduz clinicamente por um compósito rígido e denso ${ }^{49}$. Isto possibilitou avaliar a influência das diferentes intensidades de luz sobre esta resina no presente trabalho, baseando-se na suposição de que a mesma, possuindo alto índice de conversão dos radicais, fica mais susceptível ao tipo de irradiação quando comparada a outros compósitos, gerando altas tensões de contração de polimerização ${ }^{97}$. Devido ao seu alto volume de carga (66\% em volume) ${ }^{97}$, a resina composta Z100 apresenta elevado módulo de elasticidade, o que pode resultar em uma maior tensão a ser transferida para a interface $\operatorname{adesiva}^{15,151}$ e na conseqüente formação de fendas marginais ${ }^{97}$.

$\mathrm{O}$ alto módulo de elasticidade da resina composta $\mathrm{Z100}{ }^{117}$, associado à facilidade em desenvolver alta tensão de contração durante a polimerização, são fatores que influenciam na adaptação marginal das restaurações ${ }^{148}$. Essas características inerentes ao material justificam a 
sua utilização em recentes trabalhos relatados na literatura ${ }^{5,29,57,61,97,118,137}$, os quais avaliaram os diferentes aspectos relacionados com a contração de polimerização das resinas compostas.

\section{2 - Análise dos Resultados}

A infiltração marginal pode estar relacionada a vários fatores, dentre eles à diferença de coeficiente de expansão térmica entre o material restaurador e as estruturas dentárias ${ }^{106}$, às deformações do dente e do material restaurador durante a mastigação e à contração proveniente da polimerização das resinas compostas ${ }^{36}$.

A análise da contração de polimerização torna-se essencial, pois esta é uma característica inerente às resinas compostas e acontece durante a conversão dos monômeros em polímeros, constituindo-se um dos fatores que mais contribui para o insucesso das restaurações realizadas, especialmente com relação à integridade marginal ${ }^{19,21,36,63,120}$. A conversão das duplas ligações de carbono para ligações simples covalentes, durante a formação da rede polimérica, é sempre acompanhada pela contração do material resinoso, devido à aproximação molecular ${ }^{156}$ resultante do encurtamento da distância intermolecular de $0,3-0,4 \mathrm{~nm}$ para aproximadamente $0,15 \mathrm{~nm}^{102}$. Sendo assim, quanto maior a conversão dos monômeros em polímeros, maior a contração de polimerização ${ }^{36,76,113,132}$.

A força gerada por esta contração pode romper as ligações adesivas existentes entre a estrutura dentária e o material restaurador, resultando na formação de fendas e na infiltração marginal ${ }^{1,23,52,57,62,110,132}$. Se uma pequena falha na adesão da resina composta ocorre durante a contração de polimerização, a retenção da restauração pode não ser afetada, porém o selamento pode estar comprometido ${ }^{23,40}$.

As tensões geradas durante a contração da resina composta podem comprometer não somente a integridade marginal, mas também as suas propriedades físicas ${ }^{21,46}$. Alguns autores relataram que a utilização de bases cavitárias de cimento de ionômero de vidro ${ }^{51,83,144,145,146}$ ou o emprego de técnicas de fotoativação, com monitoramento da intensidade de luz ${ }^{57,88,147,148}$, poderiam minimizar os efeitos da contração de polimerização, atenuando a geração de tensões na interface adesiva e, conseqüentemente, reduzindo a infiltração marginal.

Considerando que a análise estatística empregada (Análise de Variância a dois critérios de classificação) não revelou interação entre as variáveis estudadas, ou seja, técnicas de fotoativação e bases de ionômero de vidro, a discussão dos resultados será realizada separadamente, enfocando os aspectos relevantes de cada uma. 


\subsection{1 - Técnicas de fotoativação X Microinfiltração}

A contração das resinas compostas pode ser dividida em fase pré-gel e pós-gel, sendo que a contração total do material implica na conjunção de ambas. Durante a contração de polimerização, que ocorre na fase denominada pré-gel, as moléculas podem deslizar e adquirir novas posições e orientações, compensando a tensão da contração de polimerização ${ }^{28,57,113,120}$. Nesta fase, a tensão gerada não é transferida para a interface de união, devido à capacidade de escoame nto das moléculas ${ }^{28,46,57,137}$. O momento em que a resina passa do estado fluido para o estado viscoso é conhecido como ponto gel e, a partir dele, na denominada fase pós-gel, o material adquire um alto módulo de elasticidade, perde a capacidade de escoamento e passa a transferir a tensão gerada no material para a interface dente-restauração ${ }^{19,28,36,66,113,120,148}$.

Considerando que as tensões são transferidas para a interface adesiva a partir do ponto gel, quanto mais longa a fase pré-gel, menor será a quantidade de tensões transferidas. Assim, uma importante característica das resinas quimicamente ativadas é a menor tensão de contração desenvolvida durante a polimerização, em virtude da sua fase pré-gel ser mais longa; afinal estes materiais apresentam uma reação de polimerização lenta e progressiva ${ }^{15,23}$. Por outro lado, as resinas fotopolimerizáveis sofrem uma polimerização mais rápida, onde a geleificação ocorre dentro de segundos após a exposição do material à fonte de luz, dificultando o controle da reação de polimerização pelo profissional ${ }^{23,120}$. Teoricamente, não há tempo suficiente para o seu escoamento e, quanto menor esta capacidade maiores as tensões de contração, as quais podem ser decisivas para o sucesso do procedimento adesivo na interface dente-restauração ${ }^{15,23}$.

A velocidade com que uma resina foto-ativada atinge o ponto gel é dependente da intensidade de luz aplicada no momento inicial da polimerização ${ }^{138}$. Dessa maneira, alguns estudos têm sugerido que a adaptação marginal das resinas compostas pode ser melhorada através da fotoativação do material somente em baixa intensidade de luz $z^{15,38,76,148}$, pois a conversão dos monômeros em polímeros aconteceria lentamente, permitindo melhor escoamento do material e redução da tensão de contração na resina $\operatorname{composta}^{38,46,147,148,155}$. Porém, a baixa intensidade de luz pode não proporcionar uma adequada polimerização da resina composta ${ }^{7}$, correndo-se o risco de uma incompleta conversão e, conseqüentemente reduzida longevidade da restauração pelo comprometimento das propriedades mecânicas e físicas do material ${ }^{52,70,88}$. Entretanto, esses problemas podem ser minimizados pelo aumento do tempo de irradiação ou por uma irradiação adicional com alta intensidade de luz ${ }^{35,52,84}$. 
Neste estudo, a irradiação inicial em baixa intensidade e a adicional, com alta intensidade de luz, foram realizadas mediante a utilização de aparelhos como o Elipar Trilight (ESPE) e o VIP (Bisco), os quais permitiram o emprego das técnicas graduais em rampa e pulso, respectivamente ${ }^{19,27}$. MEHL; HICKEL; KUNZELMANN ${ }^{88}$ (1997) relataram que a baixa intensidade de luz inicial pode não ativar as moléculas do iniciador suficientemente para o início de uma adequada reação e, então, a conversão desse material não polimerizado poderia ser realizada pela fotoativação final, com alta intensidade.

Diversos autores afirmaram que a fotoativação inicial do material com baixa intensidade de luz, seguida pela alta intensidade, minimiza as tensões geradas pela contração, devido ao prolongamento da fase pré-gel da resina composta $27,35,43,52,57,66,75,88,118,154,157$. Desta forma, a redução na velocidade de polimerização da resina, com a utilização da técnica gradual, permitiria um maior alívio das tensões, por permitir um maior escoamento das moléculas pela superfície não aderida, reduzindo a tensão proveniente da contração $^{14,40,43,52,57,88,97,118,147,155}$. Isto resultaria em menor formação de fendas marginais e na melhor adaptação do material às paredes cavitárias ${ }^{46,57,66,88,97,118,147,154,157}$, sem, no entanto, prejudic ar as suas propriedades físicas ${ }^{88}$, mecânicas e a profundidade de polimerização ${ }^{40}$.

Os resultados apresentados na Tabela 6 não revelaram diferenças estatísticas significantes nas médias de infiltração marginal entre os grupos fotoativados pela técnica convencional $(0,51 \mathrm{~mm})$ e as graduais em rampa $(0,49 \mathrm{~mm})$ e pulso $(0,59 \mathrm{~mm})$, concordando com os resultados de outros autores $5,25,33,52,119$, os quais não encontraram vedamento marginal superior em restaurações de resina composta, quando a técnica gradual foi comparada à convencional.

Torna-se importante observar que o alto fator de configuração da cavidade, a técnica de inserção única e a composição da resina composta são fatores que exacerbam as alterações dimensionais do material, podendo comprometer a interface adesiva, principalmente se associados. Diante da combinação de todas as situações limítrofes acima citadas, as quais foram padronizadas em todos os grupos experimentais deste estudo, podia-se esperar que a fotoativação da resina composta com as técnicas em rampa e pulso (graduais) apresentasse redução significante nos valores de infiltração pela modulação das intensidades de luz, permitindo melhor escoamento e liberação das tensões do material ${ }^{40,43,52,57,88,118,147}$, em comparação à técnica convencional, porém este fato não foi observado.

Uma possível explicação para os resultados obtidos poderia estar baseada no estudo de ERNST et al. $^{43}$ (2000), o qual observou que a técnica de fotoativação gradual foi capaz de 
reduzir a tensão resultante da polimerização na maioria das resinas compostas testadas, porém este efeito mostrourse menos efetivo nas resinas que contêm alta concentração de fotoiniciadores sensíveis à luz ou em materiais que são mais elásticos ${ }^{43}$. Os autores comentaram, com base em outros estudos que utilizaram a Z100, que, provavelmente, a alta quantidade de fotoiniciadores presentes nesta resina composta poderia causar um início imediato da reação de polimerização, alcançando o ponto gel ainda em baixa intensidade de luz. Como a resina composta Z100 é um compósito muito sensível à exposição da luz e se polimeriza rapidamente ${ }^{66}$, o enrijecimento do material seria alcançado dentro de poucos segundos após o início da fotoativação, aumentando as tensões da contração e prejudicando a adesão na interface, independente da técnica de fotoativação utilizada (convencional ou gradual).

Outro fato a ser analisado é que a técnica de fotoativação em rampa foi provavelmente efetuada por poucos segundos em baixa intensidade, o que pode ter permitido que grande parte do material tenha sido polimerizado em alta intensidade de luz $\left(800 \mathrm{~mW} / \mathrm{cm}^{2}\right)$. A mesma situação pode ter acontecido com a técnica do pulso, pois $3 \mathrm{~s}$ a $200 \mathrm{~mW} / \mathrm{cm}^{2}$ é um tempo curto para o início da reação e liberação das tensões, sendo que, após 3 minutos, foi aplicada a alta intensidade a $600 \mathrm{~mW} / \mathrm{cm}^{2}$ por $30 \mathrm{~s}$. A ausência de diferenças estatísticas entre as técnicas graduais e a convencional pode ser justificada pelas intensidades iniciais de luz, as quais não permaneceram baixas por tempo suficiente para permitir uma lenta reação de polimerização e relaxamento das tensões de contração ${ }^{4}$. Assim, somente a alta intensidade de luz emitida teria atuado de forma mais predominante, quando do emprego de ambas as técnicas de fotoativação gradual. Conseqüentemente, a provável incapacidade de anular as forças geradas pela contração de uma resina de rápida polimerização (Z100), quando da utilização das técnicas graduais, assemelhou-se à encontrada com a técnica convencional ${ }^{119}$. Isto pode ser demonstrado pelas médias de infiltração que não diferiram significativamente quando comparados os grupos com base de Vitrebond (0,25/ 0,18/ 0,22), base de Ketac Bond (0,31/ $0,38 / 0,37)$ e sem base $(0,64 / 0,49 / 0,38)$, para as técnicas convencional, rampa e pulso, respectivamente.

Como a fotoativação da resina composta é considerado um procedimento que consome tempo clínico, fontes que utilizam alta intensidade de luz e aumentam a velocidade de polimerização, como as de arco plasma de xenônio, foram introduzidas no mercado ${ }^{19,35,60,89,103}$. Essas lâmpadas desenvolvem um potencial elétrico extremamente alto entre dois eletrodos, localizados em uma câmara pressurizada, na qual encontra-se um gás 
inerte (xenônio). O termo "plasma" refere-se ao gás ionizado à alta temperatura, composto por elétrons e íons positivos ${ }^{113}$.

O Apollo 95E (Dental Medical Diagnostic Systems), utilizado neste trabalho, é um aparelho de arco plasma, o qual propicia luz contínua por um curto período de tempo, em um estreito comprimento de onda compreendido entre 450 a $500 \mathrm{~nm}^{35,103,113}$. Sua densidade de potência acima de $1.000 \mathrm{~mW} / \mathrm{cm}^{2}$ permite uma grande concentração de energia em uma pequena área ${ }^{35}$.

Analisando-se a Figura 14, pode-se observar que os grupos fotoativados pela técnica de alta intensidade de luz (grupos 10, 11 e 12) apresentaram valores significativamente maiores de infiltração marginal $(0,93 \mathrm{~mm})$, quando comparados com os grupos que utilizaram as técnicas em rampa $(0,49 \mathrm{~mm})$, pulso $(0,59 \mathrm{~mm})$ e convencional $(0,51 \mathrm{~mm})$, sendo os mesmos resultados encontrados por CAVALCANTI; SANTOS; SILVA e SOUZA JÚNIOR ${ }^{25}$.

A alta infiltração marginal observada nos três últimos grupos deste estudo pode ser atribuída à alta densidade de potência irradiada $\left(1.600 \mathrm{~mW} / \mathrm{cm}^{2}\right)$, em um curto tempo de exposição (3s), a qual pode ter gerado um desenvolvimento mais rápido das tensões da contração pela rápida velocidade da reação de polimerização ${ }^{15,16,35,99}$. Assim, a limitação no relaxamento das tensões ${ }^{88,148}$ pode ter produzido estresses excessivos sobre as ligações adesivas, que resultaram em uma deficiente adaptação marginal ${ }^{16}$, independente da presença ou ausência da base de ionômero de vidro.

A literatura tem mostrado maiores índices de infiltração marginal nas restaurações de resina composta fotoativadas com o aparelho de arco plasma, quando comparadas com as fotoativadas com fonte de luz halógena ${ }^{16,137}$. As forças provenientes da contração do material podem aumentar frente a uma maior intensidade de luz ${ }^{15}$, porém torna-se importante ressaltar que a alta intensidade não induz necessariamente a maiores tensões de contração nas resinas compostas, quando comparada às fontes halógenas; mas a contração é que se desenvolve mais rapidamente ${ }^{35,99}$. UNTERBRINK; MUESSNER ${ }^{148}$ (1995) observaram que a fotoativação da Z100 com alta intensidade de luz propiciou uma menor adaptação marginal, quando comparada à resina composta Tetric, independente do sistema adesivo utilizado. Desta maneira, a maior infiltração nos espécimes irradiados com a técnica de alta intensidade pode, em parte, ser explicada pela alta e rápida tensão de contração e pelo desenvolvimento do módulo de elasticidade da resina Z100, os quais podem ter sido exacerbados com a utilização de uma elevada intensidade de luz. Segundo VERLUIS; TANTBIROJN ${ }^{150}$, a alta contração do material não resulta necessariamente em elevada tensão, quando o material restaurador 
apresenta baixo módulo de elasticidade, ou seja, a interface das restaurações realizadas com resinas que apresentam baixo módulo de elasticidade tende a sofrer menor influência das tensões provocadas pela contração de polimerização.

Outra possível explicação para os maiores valores de infiltração, quando utilizada a técnica de alta intensidade, seria a incompleta polimerização da resina composta, acarretando em uma adesão deficiente e no conseqüente aumento da microinfiltração ${ }^{16,137}$. O curto tempo de exposição do material à luz pode ter sido insuficiente para a excitação da canforoquinona nas partes mais profundas, limitando a reação com a amina ${ }^{99}$. STRITIKUS; OWENS ${ }^{137}$ (2000), relataram que as restaurações de resina composta, realizadas em cavidades de classe I, mostraram maior infiltração marginal quando fotoativadas por $10 \mathrm{~s}$ em alta intensidade de luz $\left(1.196 \mathrm{~mW} / \mathrm{cm}^{2}\right)$ com o aparelho de arco plasma, quando comparadas às fotoativadas por $40 \mathrm{~s}$ com um aparelho convencional $\left(500 \mathrm{~mW} / \mathrm{cm}^{2}\right)$. Comentaram que 10 s de fotoativação parecem ser insuficientes para a polimerização do material e, possivelmente, maiores tempos de exposição produziriam menor infiltração. As mesmas observações foram feitas por PARK et al. ${ }^{99}$ (2002), os quais verificaram que as resinas compostas (Z100 e Tetric Ceram) mostraram baixa contração de polimerização quando fotoativadas por dois ou três segundos com o Apollo 95E, concluindo que não polimerizaram o suficiente. Os autores recomendaram 12 segundos de fotoativação para uma profundidade de $2 \mathrm{~mm}$ da resina composta Z100. No presente estudo, realizourse a fotoativação dos incrementos únicos de resina, com espessuras de $1,0 \mathrm{~mm}$ e $1,5 \mathrm{~mm}$, por apenas 3 segundos. Porém, de acordo com a literatura, seria necessário um tempo maior de exposição para uma adequada polimerização do material e obtenção de uma menor infiltração marginal. Alguns autores comentaram que a atuação na estreita faixa de comprimento de onda da fonte de arco plasma (440-500nm), comparada ao maior espectro de emissão de luz das lâmpadas halógenas (400-520nm), pode ter resultado em uma incompleta polimerização da resina, que, submetida às tensões térmicas, teria produzido fraca adesão e aumento da infiltração nos grupos irradiados com alta intensidade de luz ${ }^{16,99}$. No entanto, os resultados encontrados no presente estudo não podem ser justificados por tais razões, uma vez que não foi analisada a correlação existente entre subpolimerização da resina composta e infiltração marginal.

HASEGAWA et al. ${ }^{61}$ (2001) afirmaram que a utilização da lâmpada de xenônio é vantajosa para polimerização, pois é possível reduzir o tempo clínico, sem danificar a integridade marginal, se a superfície dentinária for tratada com um adequado sistema adesivo. Porém, observaram que a Z100 apresentou menor adaptação marginal quando comparada às 
outras resinas testadas, podendo ser explicada pela maior velocidade de polimerização do material. KNEZEVIC et al. ${ }^{69}$ (2002) consideraram que a fotoativação com o aparelho de arco plasma, por um curto tempo de exposição (5s), é uma alternativa para as lâmpadas halógenas (40s), pois, apesar de induzir a uma rápida polimerização, os autores relataram que gera menor tensão de contração e possibilita um grau de conversão similar ao obtido com as fontes halógenas. Contudo, observou-se um menor grau de conversão da Z100 comparada a outras resinas, quando irradiada tanto com o aparelho de arco plasma quanto com a fonte de luz halógena. Diante desses estudos, pode-se observar que existe uma relação entre composição do material restaurador e intensidade de luz. Apesar das vantagens do aparelho de arco plasma acima relatadas, estas não podem ser atribuídas quando da utilização da resina composta Z100, devido às características apresentadas por este material.

Observando-se as médias de infiltração apresentadas na Figura 15, nota-se que a utilização da base de ionômero de vidro modificado por resina (Vitrebond) propiciou menores índices de infiltração marginal em relação ao convencional (Ketac Bond), quando as técnicas convencional e graduais (rampa e pulso) foram testadas. Porém, quando a técnica de alta intensidade foi empregada, a infiltração nos espécimes que receberam base de Vitrebond mostrou-se superior aos valores observados com base de Ketac Bond. O Vitrebond é um cimento de ionômero de vidro modificado por resina de presa dual, ou seja, parte polimerizase quimicamente (reação ácido-base) e parte com a fotoativação do material. Autores como BOURKE; WALLS; McCABE ${ }^{13}$ (1992) observaram que sua reação de presa continua após a exposição à luz e o seu módulo de elasticidade (enrijecimento) aumenta gradualmente, até a sua estabilização 24 horas após. No presente estudo, provavelmente, a alta intensidade irradiada $\left(1.600 \mathrm{~mW} / \mathrm{cm}^{2}\right)$ sobre a resina composta pode ter induzido a um rápido aumento do módulo de elasticidade do Vitrebond, o qual não se encontrava bem polimerizado (ainda em fase de maturação), levando a sua rápida contração. Adicionalmente, o material pode não ter resistido às tensões induzidas pela contração da resina composta (pois já se encontrava rígido), implicando em falhas na interface adesiva, quando comparado ao ionômero de vidro convencional.

Assim, parece existir uma relação linear entre a velocidade da contração de polimerização e a intensidade de luz utilizada para a fotoativação das resinas compostas ${ }^{121,129}$.

Outros fatores de fundamental importância na análise da microinfiltração são a capacidade de união do sistema adesivo e a configuração do preparo cavitário, os quais também exercem efeito na adaptação da resina composta às paredes cavitárias $28,57,66$. 
A utilização de um bom sistema adesivo dentinário pode otimizar o selamento marginal, contrapondo-se aos efeitos da contração de polimerização ${ }^{23}$ e da tensão induzida pela ciclagem térmica ${ }^{110}$. Assim, utilizourse o Single Bond (3M ESPE) no presente trabalho, pois, de acordo MASOTTI et al. $^{82}$ (2002), este adesivo não apresentou diferença estatisticamente significante quando aplicado e avaliado quanto à resistência de união à dentina, tanto in vitro $(14,91 \mathrm{MPa})$ quanto in vivo (11,09 $\mathrm{MPa})$. Segundo o fabricante, sua resistência adesiva é de $28 \mathrm{MPa}$ em dentina, além de conter água e álcool como solventes.

Até recentemente, aceitava-se o conceito de que as resinas fotoativáveis contraíam em direção à luz, enquanto as quimicamente ativadas contraíam em direção ao centro da massa ${ }^{135}$. Posteriormente, VERSLUIS; TANTBIROJN; DOUGLAS ${ }^{152}$, em 1998, estudaram a direção da contração de ambos os tipos de resina e, comparando-as, observaram que a direção de contração dos compósitos é afetada pelo formato cavitário, pelo grau de conversão da resina e por condições referentes ao condicionamento e adesão ao esmalte e dentina. Uma vez que as paredes cavitárias são preparadas adequadamente com o sistema adesivo, então a resina composta, quando fotoativada, irá contrair em direção às paredes e não em direção à fonte de luz. Assim, verificaram que a qualidade de adesão é o fator determinante dos vetores de contração.

Este conceito torna-se mais complexo mediante o formato da cavidade e a tensão que ocorre no interior do material durante o processo de polimerização ${ }^{135}$, fatores que devem ser considerados neste estudo. O formato da cavidade está relacionado ao fator de configuração cavitária, que é definido como a relação existente entre o número de superfícies aderidas pelas superfícies não aderidas ou livres. As superfícies livres permitem o escoamento do material durante a contração de polimerização, minimizando as tensões na interface de adesão ${ }^{23}$. Sabese que as forças geradas durante a polimerização da resina composta causam uma elevada tensão, principalmente nos materiais restauradores com alto módulo de elasticidade ${ }^{66}$, como é o caso da Z100. Assim, a presença de várias superfícies unidas provavelmente limitou o alívio das tensões do compósito nas cavidades, devido ao alto fator $\mathrm{C}(\mathrm{C}=5)$, representando um desafio para a integridade na interface dente-restauração $0^{75,113,135,158,159}$ e aumentando, conseqüentemente, a infiltração do corante em todos os grupos experimentais testados no presente trabalho.

$\mathrm{O}$ elevado fator $\mathrm{C}$ das cavidades de classe $\mathrm{V}$ deste estudo, juntamente com a inserção da resina composta em um único incremento, propiciaram um significativo desafio ao material restaurador e à interface ${ }^{75}$. Diante de um alto fator $\mathrm{C}$ e da técnica de inserção única, 
aumentam-se as tensões da contração ao nível da interface, podendo ocasionar a formação de fendas marginais ${ }^{158}$ e subseqüente infiltração marginal, justificando, parcialmente, a grande quantidade de espécimes com infiltração encontrada nesse trabalho (Anexos de 1 a 4). A inserção do material em um único incremento tem sido utilizada em diversos estudos que avaliaram a adaptação margina $1^{42,75,79,88,148,157}$, e tem-se observado que é possível reduzir as tensões, quando da inserção única da resina composta, através da modulação da intensidade de luz durante a fotoativação ${ }^{75,88,147}$. Entretanto, isso não foi observado no presente estudo, pois a fotoativação do material pelas técnicas gradual e convencional revelaram resultados estatisticamente similares de infiltração. Para AMARAL et al. ${ }^{4}$ (2002), a técnica de inserção de escolha deve ser aquela que garanta uma boa adaptação e a polimerização adequada do material restaurador.

Outro fato a ser considerado é que a contração da resina durante a polimerização resulta na indução de tensões na interface adesiva, podendo romper a adesão entre dente e restauração; contudo, a polimerização e, conseqüentemente, a contração continuam após a remoção da fonte de luz ${ }^{38,156}$. Por isso, esses materiais devem ser armazenados em água para que ocorra uma expansão volumétrica, a qual compensa parcialmente a contração de polimerização $^{156}$, podendo melhorar a adaptação marginal da restauração sem, no entanto, restabelecer a ligação adesiva ${ }^{110}$. Clinicamente, este processo é complexo e varia de acordo com o formato cavitário e o volume de resina composta ${ }^{23}$. Optou-se, neste estudo, por um tempo de espera de 6 dias previamente aos procedimentos de acabamento e polimento, pois a absorção de água é máxima nos seis primeiros dias, havendo um equilíbrio após esse período $^{98}$. Enquanto a contração de polimerização é rápida e ocorre durante a polimerização, a expansão higroscópica é um processo lento que pode levar dias $23,36,110,156$.

Desta forma, a associação dos diversos fatores analisados e comentados deve ser considerada para a correta interpretação dos resultados de infiltração marginal. Afinal, a tensão gerada na interface adesiva não é apenas resultado da contração de polimerização da resina composta, mas de uma associação de diversos fatores, que podem exacerbar essas tensões e que influenciam na qualidade marginal das restaurações. 


\subsection{2 - Bases de ionômero de vidro X Microinfiltração}

Além da introdução de recentes técnicas de fotoativação, vários materiais restauradores estão sendo estudados como meios eficazes na redução da infiltração nas margens cavitárias.

Como resultado do desenvolvimento de materiais restauradores, os cimentos de ionômero de vidro foram introduzidos no mercado, advogando possuírem propriedades adesivas às estruturas dentárias, em especial nas margens localizadas em dentina ${ }^{58}$. A adesividade que ocorre através da união dos grupamentos carboxílicos com os íons cálcio da estrutura dentária no momento de presa, o coeficiente de expansão térmica linear similar ao da

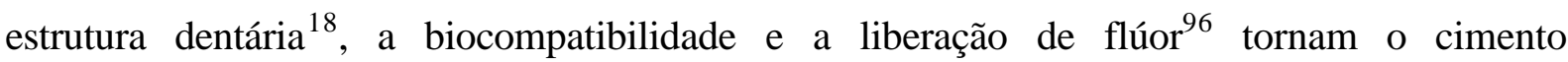
ionomérico o material de escolha na redução de um dos principais problemas da odontologia, que é a infiltração marginal ${ }^{65,83,93,125,128,130}$. Desta maneira, as propriedades dos cimentos de ionômero de vidro tornam esses materiais aceitáveis para serem utilizados como uma camada intermediária entre a resina composta e a dentina ${ }^{8,9,59,64,65,80,83,125,133,144,146}$.

Devido a questionamentos a respeito da capacidade de adesão e redução da infiltração dos cimentos de ionômero de vidro modificados por resina e convencionais, optoutse por avaliar as diferenças nos índices de microinfiltração, quando ambos foram utilizados como base sob restaurações de resina composta. O Vitrebond (3M ESPE) tem sido utilizado em diferentes trabalhos existentes na literatura ${ }^{42,74,93,133,145}$, assim como o Ketac Bond (3M ESPE) $)^{9,32,42,53,58,93,106,125,144}$, sendo ambos selecionados para este estudo in vitro, por serem os materiais de escolha para margens susceptíveis à cárie, além da capacidade de minimizar a infiltração marginal ${ }^{42}$.

Os resultados do presente estudo não mostraram diferenças estatisticamente significantes de infiltração marginal entre os cimentos de ionômero de vidro modificado por resina e convencional, quando ambos foram empregados como bases (Tabela 7), confirmando os resultados encontrados por outros autores ${ }^{42,134}$. BRACKETT et al. ${ }^{17}$ (1995) e SILVA et al. ${ }^{130}$ (2000) avaliaram a microinfiltração em diferentes cimentos de ionômero de vidro e não observaram diferenças significantes entre o modificado por resina e o convencional, quando utilizados para restaurações de classe $\mathrm{V}$.

No entanto, os resultados mencionados e os deste estudo são contrários a diversos outros relatados na literatura, os quais têm indicado a aplicação de uma base de cimento de ionômero de vidro modificado por resina ao invés do convencional, por este apresentar 
melhor adesão à estrutura dentária ${ }^{26,64,74,90} \mathrm{e}$, conseqüentemente, maior eficiência em reduzir a infiltração marginal, principalmente nas margens dentinárias, 1,9,26,90,128,144. Alguns pesquisadores afirmaram que a capacidade de retenção e vedamento marginal dos híbridos provavelmente ocorre por aderirem-se à estrutura dentária similarmente aos convencionais, mas também por possuírem, em parte, capacidade adesiva micromecânica similar aos sistemas resinosos, potencializando sua força de união ${ }^{26}$.

Teoricamente, a contração de polimerização do componente resinoso presente nos cimentos de ionômero de vidro híbridos poderia acarretar em um maior potencial para a microinfiltração, quando comparado aos convencionais ${ }^{26,64}$; afinal estes últimos deveriam apresentar maior possibilidade de obter um bom selamento marginal, pela liberação das tensões que ocorre durante a sua prolongada reação de presa ${ }^{134}$.

Apesar deste estudo não revelar superioridade estatística da base de ionômero de vidro modificado por resina em prevenir a infiltração quando comparado ao convenciona ${ }^{42}$, a Figura 15 demonstra predominância de uma menor infiltração marginal nos grupos que receberam base de ionômero modificado por resina (Vitrebond). TJAN; DUNN ${ }^{144}$ (1990) atribuíram o melhor comportamento dos cimentos híbridos ao seu momento de presa, no qual obtêm uma adesão alta e imediata à dentina, que é capaz de resistir às forças de contração geradas durante a polimerização da resina composta ${ }^{1}$. MITRA ${ }^{90}$ (1991) revelou que a imediata adesão do ionômero modificado à dentina bovina é de $7 \pm 2 \mathrm{MPa}$, a qual é significativamente maior que a dos quimicamente ativados $(2 \pm 1 \mathrm{MPa})$, sugerindo sua indicação sob restaurações de resina composta, aliado às suas boas propriedades físicas. HOLTAN et al. ${ }^{64}$ (1990) observaram significante maior resistência adesiva do Vitrabond à dentina (8,03MPa) em relação ao Ketac Bond (4,71MPa). Esta relativa forte adesão inicial ${ }^{1,47,74,91,134}$ minimiza a formação de fendas e reduz a probabilidade de microinfiltração ${ }^{1,67,80,144}$.

Comparando-se os resultados dos grupos que receberam bases de ionômero de vidro com os restaurados somente com resina composta, observaram-se valores significativamente maiores de infiltração em todos os grupos que não receberam bases (Figura 15), confirmando os resultados encontrados por outros autores ${ }^{59,83,125,133,140}$. A maior infiltração do corante nos grupos restaurados somente com resina composta pode ser atribuída ao alto módulo de elasticidade do material restaurador (Z100), pois quanto maior o seu valor, menor a flexibilidade e o alívio das tensões, o que influencia diretamente no vedamento marginal em restaurações de resina composta ${ }^{148}$. É conhecido que resinas com alto conteúdo de carga, como a selecionada para este estudo, apresentam maiores escores de infiltração marginal em 
relação a compósitos de menor rigidez ${ }^{15}$, portanto a contração do material mais rígido causará maiores tensões na interface adesiva. Então, a associação da rigidez relativamente alta da estrutura dentária ${ }^{66,132}$, com a apresentada pela resina composta Z100 pode ter dificultado a assimilação de tensões geradas durante a contração de polimerização ${ }^{132}$.

Desta forma, a utilização do cimento de ionômero de vidro sob a resina composta é vantajosa pelo mesmo apresentar baixo módulo de elasticidade e, conseqüentemente, aliviar as tensões provenientes da contração de polimerização ${ }^{51}$ e da mastigação. Os valores significativamente menores de infiltração, presentes em todos os grupos que receberam base de ionômero de vidro, independente do tipo (convencional ou modificado por resina) e da técnica de fotoativação (Figura 15), podem ser justificados, em parte, pelo baixo módulo de elasticidade do cimento de ionômero de vidro convencional ${ }^{34}$ e do modificado por resina ${ }^{73,145}$, o que contribuiu para uma distribuição mais homogênea das tensões na interface adesiva ${ }^{36}$. KEMP-SCHOLTE; DAVIDSON ${ }^{67}$ (1990) observaram um alívio de 20 a 50\% da tensão da contração de polimerização, através da aplicação de uma camada intermediária entre a dentina e o material restaurador. No presente estudo, a camada intermediária foi realizada com o cimento de ionômero de vidro convencional ou modificado por resina, os quais apresentaram $0,5 \mathrm{~mm}$ de espessura ${ }^{93}$.

Como a infiltração marginal não pode ser representada por um fator isolado, as maiores infiltrações observadas nos grupos restaurados somente com resina composta podem também estar associadas à maior quantidade de resina inserida, em cavidades com alto fator C. Por outro lado, a aplicação de uma base cavitária propicia uma diminuição neste fator e no volume de material restaurador e, conseqüentemente, uma redução substancial na contração de polimerização final, por compensar, em parte, as tensões por ela geradas ${ }^{51,67,83,144,145,146}$. TOLIDIS; NOBECOURT; RANDALL ${ }^{145}$ (1998) verificaram que a aplicação do cimento de ionômero de vidro modificado por resina (Vitrebond) sob a resina composta foi capaz de absorver parte das tensões de contração da mesma, reduzindo aproximadamente $41 \%$ da contração de polimerização volumétrica.

A diferença dos coeficientes de expansão térmica entre a estrutura dentária e o material restaurador ${ }^{18}$ pode também explicar a maior penetração do corante nos grupos restaurados com resina composta. A realização de 500 ciclos de termociclagem, com banhos de imersão de 1 minuto em cada temperatura, pode ter induzido a um aumento das tensões na interface adesiva quando da utilização de um maior volume de resina, material este que não apresenta esse coeficiente próximo ao da estrutura dentária. Entretanto, a utilização do 
ionômero de vidro sob a resina composta minimizaria a infiltração, pois os efeitos da contração de polimerização e expansão térmica da resina são reduzidos devido à menor quantidade de resina presente na cavidade ${ }^{83}$.

Um outro fator importante a ser observado, ao se analisar os maiores índices de infiltração ocorridos nos grupos 1, 4, 7 e 10, é a resistência adesiva alcançada pelos sistemas adesivos no substrato dentinário. GIANNINI et al. ${ }^{54}$ (2001) observaram que as variações regionais na densidade dos túbulos dentinários e na área de dentina intertubular podem modificar a resistência adesiva dos sistemas adesivos. As áreas com maior quantidade de dentina intertubular apresentaram maior resistência adesiva, independente do tipo de sistema adesivo utilizado ${ }^{54}$. No presente estudo, foram realizados preparos cavitários profundos, em área com maior densidade tubular e menor quantidade de dentina intertubular ${ }^{122}$, o que pode ter contribuído para a obtenção de uma menor área adesiva disponível para a formação da camada híbrida, que é o principal mecanismo de adesão. Isto pode ser confirmado por TAGAMI; TAO; PASHLEY ${ }^{139}$ (1990), os quais utilizaram dentes bovinos e encontraram uma maior resistência adesiva em dentina superficial, quando comparada à dentina profunda. Assim, a probabilidade do sistema adesivo Single Bond ter alcançado menor resistência na dentina bovina profunda, poderia também ser outra justificativa para a maior infiltração nos grupos restaurados somente com resina composta. Por outro lado, a utilização da base de cimento de ionômero de vidro contribuiu para a redução da infiltração marginal, devido a sua característica de adesividade à dentina ${ }^{83,128}$. Afinal, autores como PRATI; PASHLEY ${ }^{104}$ (1992) demonstraram que os cimentos de ionômero de vidro são menos sensíveis às variações morfológicas e fisiológicas do substrato dentinário e apresentam boa capacidade de vedamento, reduzindo a permeabilidade da dentina ${ }^{81}$.

Os resultados do presente estudo revelaram também que somente três espécimes $(3,75$ \%) mostraram infiltração do corante entre o cimento de ionômero de vidro convencional e a resina composta ${ }^{58}$, significando que as tensões geradas pela contração e pelos diferentes coeficientes de expansão térmica entre os materiais, durante a termociclagem, não foram superiores à força de união entre os mesmos.

Adicionalmente, somente 10 espécimes dos 80 que utilizaram base, tanto de ionômero convencional quanto modificado por resina, apresentaram penetração do corante além do cimento ionomérico (12,5\%), mostrando que a tensão desenvolvida pela contração de polimerização da resina composta, aderida a ambos os tipos de ionômero de vidro, não foi capaz de romper a adesão deste material à dentina na maioria dos espécimes. Apesar de 
alguns autores não verificarem infiltração além do cimento de ionômero de vidro em nenhuma das amostras ${ }^{80,83}$, os resultados desse trabalho concordam com os achados por MARTIN; O'ROURKE ${ }^{80}$ (1993), onde a maioria da infiltração observada na interface adesiva não ultrapassou a base utilizada (Figura 16). Isto sugere que o cimento de ionômero de vidro é um material capaz de superar as tensões da contração que tendem a romper o selamento nas margens.

Notou-se também maior infiltração marginal nas paredes apicais de 99 dentes $(82,5 \%)$, quando comparados aos 21 dentes que mostraram penetração do corante nas paredes cervicais $(17,5 \%)$, o que poderia estar relacionado à orientação dos túbulos dentinários nessas regiões. Contudo, essa suposição não foi confirmada quando observado o padrão de infiltração do corante nos diferentes espécimes (Figura 17), o qual revelou que a inclinação dos túbulos dentinários em relação ao preparo cavitário foi semelhante para todos os grupos experimentais, tanto nas margens cervicais quanto nas margens apicais.

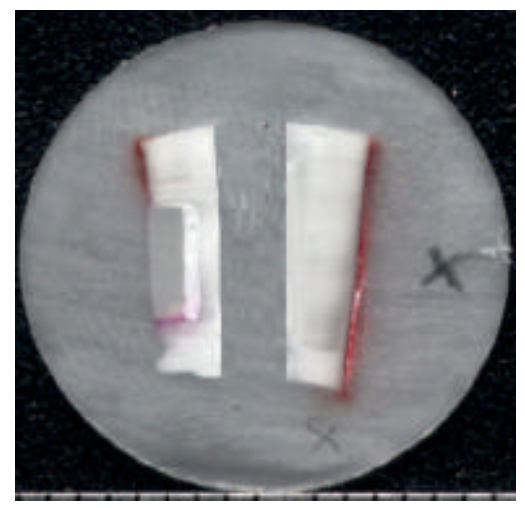

Figura 16 - Penetração do corante pela interface adesiva não ultrapassando a base de ionômero de vidro

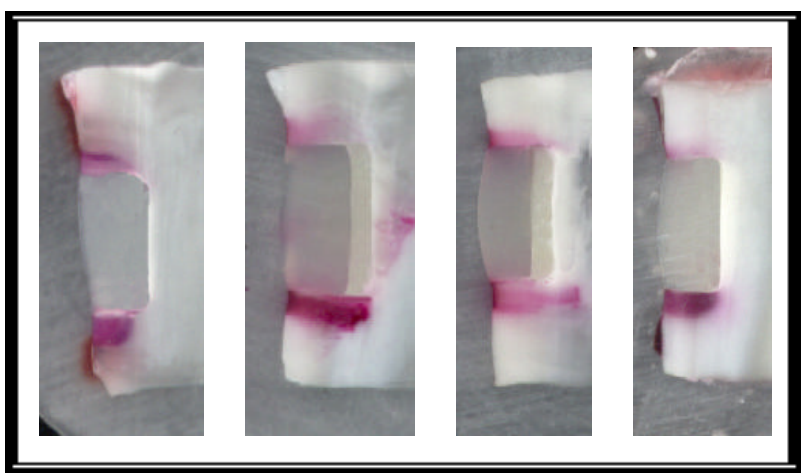

Figura 17 - Padrão de infiltração marginal em relação à disposição dos túbulos dentinários 
Devido às variáveis desse estudo se mostrarem independentes (Tabela 5), os maiores valores de infiltração foram observados nos grupos restaurados somente com resina composta ou quando a técnic a de fotoativação com alta intensidade de luz foi utilizada. Porém, a maior infiltração verificada em tais grupos está relacionada a uma associação de fatores a serem observados, quando da restauração com resina composta.

Considerando que a resina composta sofre contração durante a polimerização, a alta contração da Z100, a técnica de inserção única, o maior tempo de imersão nos banhos térmicos $(60 \mathrm{~s})$ e o alto fator de configuração cavitária $(\mathrm{C}=5)$, utilizados neste estudo, devem ser considerados fatores que, associados, contribuíram para a maior geração de tensões de contração e, conseqüentemente, para a maior penetração do corante. No entanto, devido à padronização desses fatores em todos os grupos experimentais, a maior infiltração nos grupos restaurados somente com resina composta está relacionada, principalmente, ao maior volume de resina e à ausência de um material intermediário, com baixo módulo de elasticidade, que aliviasse as tensões provenientes da contração de polimerização. A adesividade do cimento de ionômero de vidro, o coeficiente de expansão térmica similar ao da estrutura dentária e o seu baixo módulo de elasticidade foram características que, combinadas, impediram, em um número significativo de espécimes, o rompimento das ligações adesivas na interface denterestauração, quando utilizados como base. Entretanto, as diferenças nos resultados de infiltração entre as técnicas de fotoativação parecem estar associadas à intensidade de luz irradiada.

Como visto, a qualidade marginal das restaurações pode ser influenciada por fatores tais como resistência adesiva do sistema adesivo, módulo de elasticidade do material restaurador, fator $\mathrm{C}$, intensidade de luz, expansão higroscópica do material, tipo e tamanho das partículas. Portanto, o sucesso de uma restauração de resina composta depende da análise e combinação de todos esses fatores. Considerando as condições de pesquisa aqui estabelecidas, pode-se afirmar que as diferentes técnicas de fotoativação e bases de ionômero de vidro não foram capazes de impedir totalmente a infiltração marginal, em cavidades com margens localizadas em dentina.

Muitas das diferenças nos resultados, entre os estudos mencionados, podem ser atribuídas às variações nas técnicas experimentais e na forma de padronização do teste de microinfiltração in vitro. Contudo, os trabalhos laboratoriais se tornam importantes à medida que, a partir dos seus resultados, pode-se obter um melhor entendimento do significado clínico dos materiais e dos recentes métodos desenvolvidos. 
7-CONCLUSÕES 


\section{7 - CONCLUSÕES}

Baseado nos resultados devidamente analisados, obtiveram-se as seguintes conclusões:

1. A primeira hipótese deve ser aceita, pois as restaurações de resina composta com bases de cimentos de ionô mero de vidro (convencional e modificado por resina) apresentaram menores valores de infiltração marginal, independente da técnica de fotoativação utilizada.

2. A segunda hipótese deve ser rejeitada, pois as técnicas de fotoativação gradual (rampa e pulso) não foram capazes de minimizar a infiltração marginal, quando comparadas à técnica convencional, independente da base de ionômero de vidro utilizada.

3. A terceira hipótese deve ser aceita, pois as restaurações fotoativadas pela técnica de alta intensidade de luz apresentaram maiores valores de infiltração marginal quando comparada às técnicas convencional, em rampa e em pulso.

4. A quarta hipótese deve ser aceita, pois a técnica de fotoativação e o tipo de base foram considerados fatores independentes. 
ANEXOS 
Anexo 1 - Valores de infiltração marginal dos espécimes fotoativados pela técnica convencional $\left(450 \mathrm{~mW} / \mathrm{cm}^{2}\right.$ por $\left.40 \mathrm{~s}\right)$

\begin{tabular}{|c|c|c|c|c|c|}
\hline Espécime & $\begin{array}{c}\text { Infilttração } \\
\text { (mm) }\end{array}$ & Espécime & $\begin{array}{c}\text { Infiltração } \\
\text { (mm) }\end{array}$ & Espécime & $\begin{array}{c}\text { Infiltração } \\
\text { (mm) }\end{array}$ \\
\hline \multicolumn{2}{|c|}{ SEM BASE } & \multicolumn{2}{|c|}{ VITREBOND } & \multicolumn{2}{|c|}{ KETAC BOND } \\
\hline G1.01 & $1,38 \mathrm{~mm}$ & G2. 01 & $0,12 \mathrm{~mm}$ & G3. 01 & $0,08 \mathrm{~mm}$ \\
\hline G1. 02 & $0,08 \mathrm{~mm}$ & G2. 02 & $0,58 \mathrm{~mm}$ & G3. 02 & $0,42 \mathrm{~mm}$ \\
\hline G1. 03 & $0,38 \mathrm{~mm}$ & G2. 03 & $0,12 \mathrm{~mm}$ & G3. 03 & $0,33 \mathrm{~mm}$ \\
\hline G1.04 & $1,38 \mathrm{~mm}$ & G2. 04 & $0,75 \mathrm{~mm}$ & G3. 04 & $0,88 \mathrm{~mm}$ \\
\hline G1. 05 & $0,67 \mathrm{~mm}$ & G2. 05 & $0,00 \mathrm{~mm}$ & G3. 05 & $0,42 \mathrm{~mm}$ \\
\hline G1.06 & $1,42 \mathrm{~mm}$ & G2. 06 & $0,17 \mathrm{~mm}$ & G3. 06 & $0,17 \mathrm{~mm}$ \\
\hline G1. 07 & $0,00 \mathrm{~mm}$ & G2. 07 & $0,17 \mathrm{~mm}$ & G3. 07 & $0,29 \mathrm{~mm}$ \\
\hline G1. 08 & $1,5 \mathrm{~mm}$ & G2. 08 & $0,33 \mathrm{~mm}$ & G3. 08 & $0,33 \mathrm{~mm}$ \\
\hline G1. 09 & $0,08 \mathrm{~mm}$ & G2. 9 & $0,32 \mathrm{~mm}$ & G3. 09 & $1,04 \mathrm{~mm}$ \\
\hline G1. 10 & $1,42 \mathrm{~mm}$ & G2. 10 & $0,67 \mathrm{~mm}$ & G3. 10 & $0,08 \mathrm{~mm}$ \\
\hline Média & 0,8310 & Média & 0,3240 & Média & 0,4040 \\
\hline dp & 0,6491 & dp & 0,2587 & dp & 0,3197 \\
\hline
\end{tabular}


Anexo 2 - Valores de infiltração marginal dos espécimes fotoativados pela técnica em rampa $\left(100\right.$ a $800 \mathrm{~mW} / \mathrm{cm}^{2}$ por $15 \mathrm{~s}+800 \mathrm{~mW} / \mathrm{cm}^{2}$ por $\left.25 \mathrm{~s}\right)$

\begin{tabular}{|c|c|c|c|c|c|}
\hline Espécime & $\begin{array}{c}\text { Infilttração } \\
\text { (mm) }\end{array}$ & Espécime & $\begin{array}{c}\text { Infiltração } \\
\text { (mm) }\end{array}$ & Espécime & $\begin{array}{c}\text { Infiltração } \\
\text { (mm) }\end{array}$ \\
\hline \multicolumn{2}{|c|}{ SEM BASE } & \multicolumn{2}{|c|}{ VITREBOND } & \multicolumn{2}{|c|}{ KETAC BOND } \\
\hline G4. 01 & $1,38 \mathrm{~mm}$ & G5. 01 & $0,08 \mathrm{~mm}$ & G6. 01 & $0,21 \mathrm{~mm}$ \\
\hline G4. 02 & $0,29 \mathrm{~mm}$ & G5. 02 & $0,25 \mathrm{~mm}$ & G6. 02 & $1,21 \mathrm{~mm}$ \\
\hline G4. 03 & $0,88 \mathrm{~mm}$ & G5. 03 & $0,75 \mathrm{~mm}$ & G6. 03 & $0,21 \mathrm{~mm}$ \\
\hline G4. 04 & $0,33 \mathrm{~mm}$ & G5. 04 & $0,38 \mathrm{~mm}$ & G6. 04 & $1,04 \mathrm{~mm}$ \\
\hline G4. 05 & $0,08 \mathrm{~mm}$ & G5. 05 & $0,21 \mathrm{~mm}$ & G6. 05 & $0,92 \mathrm{~mm}$ \\
\hline G4. 06 & $1,38 \mathrm{~mm}$ & G5. 06 & $0,21 \mathrm{~mm}$ & G6. 06 & $0,58 \mathrm{~mm}$ \\
\hline G4. 07 & $1,00 \mathrm{~mm}$ & G5. 07 & $0,12 \mathrm{~mm}$ & G6. 07 & $0,29 \mathrm{~mm}$ \\
\hline G4. 08 & $0,21 \mathrm{~mm}$ & G5. 08 & $0,29 \mathrm{~mm}$ & G6. 08 & $0,40 \mathrm{~mm}$ \\
\hline G4. 09 & $0,29 \mathrm{~mm}$ & G5. 9 & $0,21 \mathrm{~mm}$ & G6. 09 & $0,96 \mathrm{~mm}$ \\
\hline G4. 10 & $0,38 \mathrm{~mm}$ & G5. 10 & $0,25 \mathrm{~mm}$ & G6. 10 & $0,08 \mathrm{~mm}$ \\
\hline Média & 0,6220 & Média & 0,2750 & Média & 0,5770 \\
\hline dp & 0,4928 & dp & 0,1864 & dp & 0,3889 \\
\hline
\end{tabular}


Anexo 3 - Valores de infiltração marginal dos espécimes fotoativados pela técnica por pulso $\left(3 \mathrm{~s}\right.$ a $200 \mathrm{~mW} / \mathrm{cm}^{2}+3$ minutos espera $+30 \mathrm{~s}$ a $\left.600 \mathrm{~mW} / \mathrm{cm}^{2}\right)$

\begin{tabular}{|c|c|c|c|c|c|}
\hline Espécime & $\begin{array}{c}\text { Infiltração } \\
(\mathrm{mm})\end{array}$ & Espécime & $\begin{array}{c}\text { Infiltração } \\
(\mathrm{mm})\end{array}$ & Espécime & $\begin{array}{c}\text { Infiltração } \\
(\mathrm{mm})\end{array}$ \\
\hline
\end{tabular}

SEM BASE

VITREBOND

KETAC BOND

\begin{tabular}{|c|c|c|c|c|c|}
\hline G7. 01 & $0,62 \mathrm{~mm}$ & G8. 01 & $0,29 \mathrm{~mm}$ & G9. 01 & $0,96 \mathrm{~mm}$ \\
\hline G7. 02 & $0,29 \mathrm{~mm}$ & G8. 02 & $0,42 \mathrm{~mm}$ & G9. 02 & $0,33 \mathrm{~mm}$ \\
\hline G7. 03 & $1,21 \mathrm{~mm}$ & G8. 03 & $0,46 \mathrm{~mm}$ & G9. 03 & $0,29 \mathrm{~mm}$ \\
\hline G7. 04 & $0,75 \mathrm{~mm}$ & G8. 04 & $0,25 \mathrm{~mm}$ & G9. 04 & $0,17 \mathrm{~mm}$ \\
\hline G7. 05 & $1,04 \mathrm{~mm}$ & G8. 05 & $0,25 \mathrm{~mm}$ & G9. 05 & $1,25 \mathrm{~mm}$ \\
\hline G7. 06 & $1,38 \mathrm{~mm}$ & G8. 06 & $0,21 \mathrm{~mm}$ & G9. 06 & $0,08 \mathrm{~mm}$ \\
\hline G7. 07 & $1,17 \mathrm{~mm}$ & G8. 07 & $0,54 \mathrm{~mm}$ & G9. 07 & $0,62 \mathrm{~mm}$ \\
\hline G7. 08 & $1,50 \mathrm{~mm}$ & G8. 08 & $0,08 \mathrm{~mm}$ & G9. 08 & $0,58 \mathrm{~mm}$ \\
\hline G7. 09 & $0,67 \mathrm{~mm}$ & G8. 9 & $0,88 \mathrm{~mm}$ & G9. 09 & $0,25 \mathrm{~mm}$ \\
\hline G7. 10 & $0,67 \mathrm{~mm}$ & G8. 10 & $0,25 \mathrm{~mm}$ & G9. 10 & $0,34 \mathrm{~mm}$ \\
\hline Média & 0,9300 & Média & 0,3630 & Média & 0,4870 \\
\hline$d p$ & 0,3871 & dp & 0,2256 & dp & 0,3711 \\
\hline
\end{tabular}


Anexo 4 - Valores de infiltração marginal dos espécimes fotoativados pela técnica de alta intensidade $\left(1600 \mathrm{~mW} / \mathrm{cm}^{2}\right.$ por $\left.3 \mathrm{~s}\right)$

\begin{tabular}{|c|c|c|c|c|c|}
\hline Espécime & $\begin{array}{c}\text { Infiltração } \\
(\mathrm{mm})\end{array}$ & Espécime & $\begin{array}{c}\text { Infiltração } \\
(\mathrm{mm})\end{array}$ & Espécime & $\begin{array}{c}\text { Infiltração } \\
(\mathrm{mm})\end{array}$ \\
\hline
\end{tabular}

\begin{tabular}{|c|c|c|c|c|c|}
\hline \multicolumn{2}{|c|}{ SEM BASE } & \multicolumn{2}{|c|}{ VITREBOND } & \multicolumn{2}{|c|}{ KETAC BOND } \\
\hline G10. 01 & $1,38 \mathrm{~mm}$ & G11.01 & $1,17 \mathrm{~mm}$ & G12. 01 & $0,46 \mathrm{~mm}$ \\
\hline G10. 02 & $1,46 \mathrm{~mm}$ & G11. 02 & $0,67 \mathrm{~mm}$ & G12. 02 & $1,04 \mathrm{~mm}$ \\
\hline G10. 03 & $1,04 \mathrm{~mm}$ & G11. 03 & $1,17 \mathrm{~mm}$ & G12. 03 & $1,29 \mathrm{~mm}$ \\
\hline G10. 04 & $1,29 \mathrm{~mm}$ & G11. 04 & $1,50 \mathrm{~mm}$ & G12. 04 & $1,04 \mathrm{~mm}$ \\
\hline G10. 05 & $1,42 \mathrm{~mm}$ & G11. 05 & $0,33 \mathrm{~mm}$ & G12. 05 & $0,38 \mathrm{~mm}$ \\
\hline G10. 06 & $0,38 \mathrm{~mm}$ & G11.06 & $1,12 \mathrm{~mm}$ & G12. 06 & $0,67 \mathrm{~mm}$ \\
\hline G10. 07 & $0,17 \mathrm{~mm}$ & G11. 07 & $0,42 \mathrm{~mm}$ & G12. 07 & $0,58 \mathrm{~mm}$ \\
\hline G10. 08 & $1,38 \mathrm{~mm}$ & G11. 08 & $0,92 \mathrm{~mm}$ & G12. 08 & $0,38 \mathrm{~mm}$ \\
\hline G10. 09 & $1,46 \mathrm{~mm}$ & G11.9 & $0,46 \mathrm{~mm}$ & G12. 09 & $0,96 \mathrm{~mm}$ \\
\hline G10. 10 & $1,29 \mathrm{~mm}$ & G11. 10 & $1,42 \mathrm{~mm}$ & G12. 10 & $0,83 \mathrm{~mm}$ \\
\hline Média & 1,1270 & Média & 0,9180 & Média & 0,7630 \\
\hline dp & 0,4678 & dp & 0,4247 & dp & 0,3165 \\
\hline
\end{tabular}




\section{REFERÊNCIAS BIBLIOGRÁFICAS*}

1. ABOUSHALA, A.; KUGEL, G.; HURLEY, E. Class II composite resin restorations using glass-ionomer liners: microleakage studies. J. clin. pediat. Dent., v.21, n.1, p.67-70, Fall 1996.

2. AGUIAR, F.H.B.; AJUDARTE, K.F.; LOVADINO, J.R. Effect of light curing modes and filling techniques on microleakage of posterior resin composite restorations. Oper. Dent., v.27, n.6, p.557-62, Nov./ Dec. 2002.

3. ALANI, A.H.; TOH, C.G. Detection of microleakage around dental restorations: a review. Oper. Dent., v.22, n.4, p.173-85, July/ Aug. 1997.

4. AMARAL, C.M. et al. Efeito das técnicas de inserção e ativação da resina composta sobre a microinfiltração e microdureza. Pesqu. Odont. Bras., v.16, n.3, p.257-62, jul./set. 2002.

5. AMARAL, C.M. et al. Influence of resin composite polymerization techniques on microleakage and microhardness. Quintessence Int., v.33, n.9, p.685-9, Oct. 2002.

6. ANDRADE, M.F. et al. Avaliação da microinfiltração marginal em cavidades de classe V restauradas com três tipos de cimentos ionoméricos. Odonto 2000, v.1, p.11-15, 1996.

7. ARAÚJO, R.M.; ARAÚJO, M.A.M. de; MENDES, A.J.D. Influência da intensidade de luz de fotopolimerizadores na infiltração marginal. Rev. Ass. paul. cirurg. Dent., v.50, n.5, p.408-13, set./ out. 1996.

8. ARAÚJO, M.A.M de., MELlO, J.B de., MENDES, A.J.D. Restauração de classe V: avaliação da infiltração marginal com diferentes procedimentos e materiais. Rev. Odont. UNESP, v.22, n.2, p.239-47, jul./ dez. 1993.

\footnotetext{
* Normas recomendadas para uso no âmbito da Universidade de São Paulo, com base no documento "Referências Bibliográficas": exemplos", emanado do Conselho Superior do Sistema Integrado de Bibliotecas da U.S.P., em reunião de 20 de setembro de 1990.
} 
9. ARAÚJO, M.A.M. de. et al. Avaliação da infiltração marginal na interface resina composta-cimento de ionômero de vidro e deste com a dentina. Rev. Odont. UNESP, v.24, n.1, p.69-78, jan./jul. 1995.

10. ARCORIA, C.J.; VITASEK, B.A.; FERRACANE, J.L. Microleakage of composite resin restorations following thermocycling and instrumentation. Gen. Dent., v.38, n.2, p.129-31, Mar./ Apr. 1990.

11. BARNES, D.M. et al. Microleakage of class 5 composite resin restorations: a comparison between in vivo and in vitro. Oper. Dent., v.18, n.6, p.237-45, Nov./Dec. 1993.

12. BLANKENAU R, ERICKSON RL, RUEGGEBERG F. New light curing options for composite resin restorations. Comp. Continuing Educ. Dent., v.20, n.2, p.122-34, 1999.

13. BOURKE, A.M.; WALLS, A.W.; McCABE, J.F. Light-activated glass polyalkenoate (ionomer) cements: the setting reaction. J. Dent., v.20, n.2, p.115-20, Apr. 1992.

14. BOUSCHLICHER, M.R.; RUEGGEBERG, F.A. Effect of ramped intensity on polymerization force and conversion in a photoactivated composite. J. Esthet. Dent., v.12, n.6, p.328-39, 2000.

15. BOUSCHLICHER, M.R.; VARGAS, M.A.; BOYER, D.B. Effect of composite type, light intensity, configuration factor and laser polymerization on polymerization contraction forces. Amer. J. Dent., v.10, n.2, p.88-96, Apr. 1997.

16. BRACKETT, W.W.; HAISCH, L.D.; COVEY, D.A. Effect of plasma arc curing on the microleakage of class V resin-based composite restorations. Amer. J. Dent., v.13, n.3, p.121-8, June 2000.

17. BRACKETT, W.W. et al. Microleakage of light-cured glass-ionomer restorative materials. Quintessence Int., v.26, n.8, p. 583-5, Aug. 1995.

18. BULLARD, R.H.; LEINFELDER, K.F.; RUSSELL, C.M. Effect of coefficient of thermal expansion on microleakage. J. Amer. dent. Ass., v.116, n.7, p.871-4, June 1988. 
19. BURGESS, J.O. et al. Light Curing: an update. Comp. Continuing Educ. Dent., v.23, n.10, p.889-906, Oct. 2002.

20. BURROW, M.F. et al. Bond strength to crown and root dentin. Amer. J. Dent., v.9, n.5, p.223-9, Oct. 1996.

21. CALDWELL, R.; KULKARNI, G.; TITLEY, K. Does single versus stepped curing of composite resins affect their shear bond strength? J. Canad. dent. Ass., v.67, n.10, p.588-92, Nov. 2001.

22. CARVALHO, R.M. Adesivos dentinários: fundamentos para aplicação clínica. Rev. Dent. Rest., v.1, n.2, abr./ jun. 1998.

23. CARVALHO, R.M. et al. A review of polymerization contraction: the influence of stress development versus stress relief. Oper. Dent., v.21, n.1, p.17-24, Jan./Feb. 1996.

24. CAUGHMAN, W.F.; RUEGGEBERG, F.A.; CURTIS, J.W. Clinical guidelines for photocuring restorative resins. J. Amer. dent. Ass., v.126, n.9, p.1280-4, Sept. 1995.

25. CAVAlCANTI, A.P.C.; SANTOS, M.J.M.C.; SILVA E SOUZA JÚNIOR, M.H. Influência da intensidade de luz e métodos de fotoativação no selamento marginal de restaurações de resinas compostas. Pesqu. Odont. Bras., v.16, p.53, 2002. Suplemento/ Apresentado no SBPqO - Resumo/

26. CHAIN, M.C., CHAIN, J.C., LEINFELDER, K.F. Cimentos ionoméricos híbridos: força de adesão à dentina e mecanismo de união. Rev. gaúcha Odont., v.48, n.1, p.42-9, jan./ mar. 2000.

27. CHRISTENSEN, R.P. et al. Resin polymerization problems - are they caused by resin curing lights, resin formulations or both? Comp. Continuing Educ. Dent., v.20, n.25, p.42-54, Nov. 1999.

28. COELHO SANTOS, M.J.M.; SILVA E SOUZA JÚNIOR., M.H.; MONDELLI, R.F.L. Novos conceitos relacionados à fotopolimerização das resinas compostas. J.B.D., v.1, n.1, p.14-21, jan./mar. 2002. 
29. CONSANI, S. et al. Efeito dos métodos de fotoativação e de inserção sobre a dureza de resinas compostas. Pesqu. Odont. Bras., v.16, n.4, p.355-60, out./dez. 2002.

30. CORADAZZI, J.L. et al. Shear bond strength of an adhesive system in human, bovine and swinish teeth. Rev. Fac. Odont. Bauru, v.6, n.4, p.29-33, Oct. /Dec. 1998.

31. CRIM, G.A.; CHAPMAN, K.W. Effect of placement techniques on microleakage of a dentin-bonded composite resin. Quintessence Int., v.17, n.1, p.21-4, Jan. 1986.

32. CRIM, G.A.; SHAY, J.S. Microleakage pattern of resin-veneered glass-ionomer cavity liner. J. prosth. Dent., v.58, n.3, p.273-6, Sept. 1987.

33. D'ALPINO, P.H.P. et al. In vitro evaluation of internal adaptation of class $\mathrm{V}$ resin composite restorations using three techniques of polymerization. J. dent. Res., v.81, p. A-420, 2002. Special issue. / Abstract n.3401/

34. DAUVILLIER, B.S. et al. Visco-elastic parameters of dental restorative materials during setting. J. dent. Res., v.79, n.3, p.818-23, Mar. 2000.

35. DAVIDSON, C.L.; DE GEE, A.J. de. Light-curing units, polymerization and clinical implications. J. Adhes.Dent., v.2, n.3, p.167-73, Autumn 2000.

36. DAVIDSON, C.L.; FEILZER, A.J. Polymerization shrinkage and polymerization shrinkage stress in polymer-based restoratives. J. Dent., v.25, n.6, p.435-40, Nov. 1997.

37. DAVIDSON, C.L.; DE GEE, A.J.; FEILZER, A. The competition between the compositedentin bond strength and the polymerization contraction stress. J. dent. Res., v.63, n.12, p.1396-9, Dec. 1984.

38. DAVIDSON-KABAN, S.S. et al. The effect of curing light variations on bulk curing and wall-to-wall quality of two types and various shades of resin composites. Dent. Mat., v.13, n.5/6, p.344-52, Nov. 1997.

39. DÉJOU, J.; SINDRES, V.; CAMPS, J. Influence of criteria on the results of in vitro evaluation of microleakage. Dent. Mat., v.12, n.6, p.342-9, Nov. 1996. 
40. DENNISON, J.B. et al. Effect of variable light intensity on composite shrinkage. J. prosth. Dent., v.84, n.5, p.499-505, Nov. 2000.

41. DIETRICH, T.H. et al. Marginal adaptation of direct composite and sandwich restorations in Class II cavities with cervical margins in dentine. J. Dent., v.27, n.2, p.119-28, Feb. 1999.

42. DOUGLAS, W.H.; FUNDINGSLAND, J.W. Microleakage of three generically different fluoride-releasing liner/ bases. J. Dent., v.20, n.6, p.365-9, Dec. 1992.

43. ERNST, C.P. et al. Stress reduction in resin-based composites cured with a two-step lightcuring unit. Amer. J. Dent., v.13, n.2, p.69-72, Apr. 2000.

44. FAN, P.L. et al. Curing-light intensity and depth of cure of resin-based composites tested according to international standards. J. Amer. dent. Ass., v.133, n.4, p.429-34, Apr. 2002.

45. FEILZER, A.; DE GEE, A.J.; DAVIDSON, C.L. Curing contraction of composites and glass-ionomer cements. J. prosth. Dent., v.59, n.3, p.297-300, Mar. 1988.

46. FEILZER, A.J. et al. Influence of light intensity on polymerization shrinkage and integrity of restoration-cavity interface. Eur. J. Oral Sci., v.103, n.5, p.322-6, Oct. 1995.

47. FERRARI, M.; DAVIDSON, C.L. Sealing capacity of a resin-modified glass-ionomer and resin composite placed in vivo in Class 5 restorations. Oper. Dent., v.21, n.2, p.69-72, Mar./Apr. 1996.

48. FERRARI, M.; GARCIA-GODOY, F. Sealing ability of new generation adhesiverestorative materials placed on vital teeth. Amer. J. Dent., v.15, n.2, p.117-28, Apr. 2002.

49. FILTEK Z250. Restaurador universal para dentes anteriores e posteriores: perfil técnico do produto. Saint Paul, 3M, 1998.

50. FRANCO, E.B.; LOPES, L.G. Contração de polimerização x adaptação marginal de restaurações em resina composta: abordagem atual. Rev. Fac. Odont. Passo Fundo, v.5, n.1, p.37-41, jan./jun. 2000. 
51. FRIEDL, K.H. et al. Marginal adaptation of composite restorations versus hybrid ionomer/ composite sandwich restorations. Oper. Dent., v.22, n.1, p.21-9, Jan./Feb. 1997.

52. FRIEDL, K.H. et al. Marginal adaptation of class V restorations with and without “softstart-polymerization”. Oper. Dent., v.25, n.1, p.26-32, Jan./Feb. 2000.

53. GARCIA-GODOY, F.; MALONE, W.F.P. Microleakage of posterior composite resins using glass ionomer cement bases. Quintessence Int., v.19, n.1, p.13-7, Jan. 1988.

54. GIANNINI, M. et al. The influence of tubule density and area of solid dentin on bond strength of two adhesive systems to dentin. J. Adhes. Dent., v.3, n.4, p.315-24, Winter 2001.

55. GLADYS, S. et al. Marginal adaptation and retention of a glass-ionomer, resin-modified glass-ionomers and a polyacid-modified resin composite in cervical class- $\mathrm{V}$ lesions. Dent. Mat., v.14, n.4, p.294-306, July 1998.

56. GOING, R.E. Reducing marginal leakage: a review of materials and techniques. J. Amer. dent. Ass., v.99, n.4, p.646-51, Oct. 1979.

57. GORACCI, G.; MORI, G.; MARTINIS, L.C. de. Curing light intensity and marginal leakage of resin composite restorations. Quintessence Int., v.27, n.5, p.355-62, May 1996.

58. GORDON, M et al. Microleakage of four composite resins over a glass ionomer cement base in Class V restorations. Quintessence Int., v.16, n.12, p.817-20, Dec. 1985.

59. HAGGE, M.S. et al. Gengival margin microleakage of proximocclusal resins incorporating five intermediate layers. J. dent. Res., v. 79, p.181, 2000. Special issue./Abstract n.303/

60. HAMMESFAHR, P.D.; O'CONNOR, M.T.; WANG, X. Light-curing technology: past, present, and future. Comp. Continuing Educ. Dent., v.23, p.18-24, Sept. 2002. Supplement 9. 
61. HASEGAWA, T. et al. Depth of cure and marginal adaptation to dentin of xenon lamp polymerized resin composites. Oper. Dent., v.26, n.6, p.585-90, Nov./Dec. 2001.

62. HILTON, T.J. Can modern restorative procedures and materials reliably seal cavities? In vitro investigations. Part 1. Amer. J. Dent., v.15, n.3, p.198-210, June 2002.

63. HILTON, T.J. Can modern restorative procedures and materials reliably seal cavities? In vitro investigations. Part 2. Amer. J. Dent., v.15, n.4, p.279-89, Aug. 2002.

64. HOLTAN, J.R. et al. Bond strength of light-cured and two auto-cured glass ionomer liners. J. Dent., v.18, n.5, p.271-5, Oct. 1990.

65. HOLTAN, J.R. et al. Microleakage and marginal placement of a glass-ionomer liner. Quintessence Int., v.21, n.2, p.117-22, Feb. 1990.

66. KANCA, J.; SUH, B.I. Pulse activation: reducing resin-based composite contraction stresses at the enamel cavosurface margins. Amer. J. Dent., v.12, n.3, p.107-12, June 1999.

67. KEMP-SCHOLTE, C.M.; DAVIDSON, C.L. Complete marginal seal of class V resin composite restorarions. Effect by increased flexibility. J. dent. Res., v.69, n.6, p.12403, June 1990.

68. KIDD, E.A.M. Microleakage: a review. J. Dent., v.4, n.5, p.199-206, Sept. 1976.

69. KNEZEVIC, A. et al. Photopolymerization of composite resins with plasma light. J. oral Rehab., v.29, n.8, p.782-6, Aug. 2002.

70. KORAN, P.; KÜRSCHNER, R. Effect of sequential versus continuous irradiation of a light-cured resin composite on shrinkage, viscosity, adhesion and degree of polymerization. Amer. J. Dent., v.11, n.1, p.17-22, Feb. 1998.

71. LEINFELDER, K.F. Posterior composite resins: the materials and their clinical performance. J. Amer. dent. Ass., v.126, n.5, p.663-72, May 1995.

72. LEINFELDER, K.F. What intensity is best in light curing? J. Amer. dent. Ass., v.130, p.534, Apr. 1999. 
73. LI, Z.C.; WHITE, S.N. Mechanical properties of dental luting cements. J. prosth. Dent., v.81, n.5, p.597-609, May 1999.

74. LIN, A.; McINTYRE, N.S.; DAVIDSON, R.D. Studies on the adhesion of glass-ionomer cements to dentin. J. dent. Res., v.71, n.11, p.1836-41, Nov. 1992.

75. LOPES, G.C. et al. Efeito do tempo e da intensidade de luz na microinfiltração de restaurações de resina composta. J.B.C., v.5, n.25, p.11-4, jan./fev. 2001.

76. LÖSCHE, G.M. Marginal adaptation of class II composite fillings: guided polymerization vs reduced light intensity. J. Adhes. Dent., v.1, n.1, p.31-9, Jan. 1999.

77. LUCENA-MARTIN, C. et al. Influence of time and thermocycling on marginal sealing of several dentin adhesive systems. Oper. Dent., v.26, n.6, p.550-5, Nov./Dec. 2001.

78. MANGUM, F.I. et al. Microleakage of incremental versus compression matrix bulk filling of cervical resin composite restorations. Gen. Dent., v.42, n.4, p.304-8, July/Aug. 1994.

79. MANHART, $\mathrm{J}$ et al. Marginal quality and microleakage of adhesive class $\mathrm{V}$ restorations. J. Dent., v.29, n.2, p.123-30, Feb. 2001.

80. MARTIN, F.E.; O'ROURKE, M. Marginal seal of cervical tooth-coloured restorations. A laboratory investigation of placement techniques. Aust. dent. J., v.38, n.2, p.102-7, Apr. 1993.

81. MASON, P.N.; FERRARI, M. In vivo evaluation of glass-ionomer cement adhesion to dentin. Quintessence Int., v.25, n.7, p.499-504, July 1994.

82. MASOTTI, A.S. et al. Avaliação in vivo e in vitro da resistência de união à dentina do sistema adesivo Single Bond (3M). J. B. D., v.1, n.2, p.160-4, abr./jun. 2002.

83. MATHIS, R.S. et al. Marginal leakage in class V composite resin restorations with glass ionomer liners in vitro. J. prosth. Dent., v.63, n.5, p.522-5, May 1990.

84. MAZUR, R.F. et al. Microinfiltração marginal em cavidades classe V, com resina composta submetida a diferentes intensidades de luz. Revisão de literatura. J. Bras. Clin. Odont. Int., v.5, n.28, p.307-10, jul./ago. 2001. 
85. MAZUR, R.F. et al. Análise quantitativa da microinfiltração marginal de cavidades Classe $\mathrm{V}$ em cemento com resina composta submetida às diferentes intensidades de luz. J.B.D, v.1, n.2, p.146-50, abr./jun. 2002.

86. McCABE, J.F. Resin-modified glass-ionomers. Biomaterials, v.19, n.6, p.521-7, Mar. 1998

87. McLEAN, J.W. et al. The use of glass-ionomer cements in bonding composite resins to dentine. Brit. dent. J., v.158, n.10, p.410-4, June 1985.

88. MEHL, A.; HICKEL, R.; KUNZELMANN, K.H. Physical properties and gap formation of light-cured composites with and without 'softstart-polymerization'. J. Dent., v.25, n.3-4, p.321-30, May/July 1997.

89. MILLAR, B.J.; NICHOLSON, J.W. Effect of curing with a plasma light on the properties of polymerizable dental restorative materials. J. oral Rehab., v.28, n.6, p.549-52, June 2001 .

90. MITRA, S.B. Adhesion to dentin and physical properties of a light-cured glass-ionomer liner/base. J. dent. Res., v.70, n.1, p.72-4, Jan. 1991.

91. MIYAZAKI, M. et al. Resin-modified glass ionomers: dentin bond strength versus time. Oper. Dent., v.23, n.3, p.144-9, Mar./ Apr. 1998.

92. MOUNT, G.J. Glass ionomers: a review of their current status. Oper. Dent., v.24, n.2, p.115-24, Mar./Apr. 1999.

93. MOUNT, G.J.; PAPAGEORGIOU, A.; MAKINSON, O.F. Microleakage in the sandwich technique. Amer. J. Dent., v.5, n.4, p.195-8, Aug. 1992.

94. MUENCH, A.; SILVA, E.M da.; BALLESTER, R.Y. Influence of different dentinal substrates on the tensile bond strength of three adhesive systems. J. Adhes. Dent., v.2, n.3, p.209-12, Autumn 2000.

95. NAKAMICHI, I.; IWAKU, M.; FUSAYAMA, T. Bovine teeth as possible substitutes in the adhesion test. J. dent. Res., v.62, n.10, p.1076-81, Oct. 1983. 
96. NAVARRO, M.F.L.; PASCOTTO, R.C. Cimentos de ionômero de vidro. In:

Cimentos de ionômero de vidro: aplicações clínicas em odontologia. São Paulo, Artes Médicas, 1998. Cap. 1, p.3-24.

97. OBICI, A.C. et al. Effect of the photo-activation method on polymerization shrinkage of restorative composites. Oper. Dent., v.27, n.2, p.192-8, Mar./ Apr. 2002.

98. OLIVA, R.A.; LOWE, J.A. Dimensional stability of composite used as a core material. J. prosth. Dent., v.56, n.5, p.554-61, Nov. 1986.

99. PARK, S.H.; KREJCI, I.; LUTZ, F. Microhardness of resin composites polymerized by plasma arc or conventional visible light curing. Oper. Dent., v.27, n.1, p.30-7, Jan./ Feb. 2002.

100. PAZINATTO, F.B. Efeito do condicionamento da superfície do cimento de ionômero de vidro modificado por resina e de técnicas de inserção na infiltração marginal de restaurações de resina composta. Bauru, 2003. 120p. Dissertação (Mestrado) - Faculdade de Odontologia de Bauru, Universidade de São Paulo.

101. PENTEADO, V.A.; ASMUSSEN, E. Filling of resin composites and glass-ionomers: reduced marginal gaps. Rev. Fac. Odont. Bauru., v.3, n.1/4, p.19-23, jan./dez. 1995.

102. PEUTZFELDT, A. Resin composites in dentistry: the monomer systems. Eur. J. Oral Sci, v.105, n.2, p.97-116, Apr. 1997.

103. PEUTZFELDT, A.; SAHAFI, A.; ASMUSSEN, E. Characterization of resin composites polymerized with plasma arc curing units. Dent. Mat., v.16, n.5, p.330-6, Sept. 2000.

104. PRATI, C.; PASHLEY, D.H. Dentin wetness, permeability and thickness and bond strength of adhesive systems. Amer. J. Dent., v.5, n.1, p.33-8, Feb. 1992.

105. PRATI, C. et al. Marginal morphology of class V composite restorations. Amer. J. Dent., v.10, n.5, p.231-6, Oct. 1997. 
106. PUCKETT, A. et al. The effect of incremental versus bulk fill techniques on the microleakage of composite resin using a glass-ionomer liner. Oper. Dent., v.17, n.5, p.186-91, Sept./Oct. 1992.

107. RASKIN, A. et al. Reliability of in vitro microleakage tests: a literature review. J Adhes. Dent., v.3, n.4, p. 295-308, Winter 2001

108. REEVES, G.W. et al. Microleakage of new dentin bonding systems using human and bovine teeth. Oper. Dent., v.20, n.6, p.230-5, Nov./Dec. 1995.

109. RETIEF, D.H. Standardizing laboratory adhesion tests. Amer. J. Dent., v.4, n.5, p.2316, Oct. 1991.

110. RETIEF, D.H. Do adhesives prevent microleakage? Int. dent. J., v.44, n.1, p.19-26, Feb.1994.

111. RISSI, R.C; CABRAL, A. Fotopolimerização: principais variáveis clínicas que podem interferir no processo. Rev. Ass. paul. cirurg. Dent., v.56, n.2, p.123-8, Mar./Apr. 2002.

112. ROSSOMANDO, K.J.; WENDT JUNIOR, S.L. Thermocycling and dwell times in microleakage evaluation for bonded restorations. Dent. Mat., v.11, n.1, p.47-51, Jan. 1995.

113. RUEGgeberG, F. Contemporary issues in photocuring. Comp. Continuing Educ. Dent., v.20, n.25, p.4-15, Nov.1999.

114. RUEGGEBERG, F.A.; CAUGHMAN, W.F.; CURTIS Jr., J.W. Effect of light intensity and exposure duration on cure of resin composite. Oper. Dent., v.19, n.1, p.26-32, Jan./ Feb. 1994.

115. RUEGGEBERG, F.A. et al. Factors affecting cure at depths within light-activated resin composites. Amer. J. Dent., v.6, n.2, p.91-5, Apr. 1993

116. RUEGGEBERG, F.A. et al. A predictive model for the polymerization of photoactivated resin composites. Int. J. Prosthodont., v.7, n.2, p.159-66, Mar./ Apr. 1994. 
117. SABBAGH, J.; VREVEN, J.; LELOUP, G. Dynamic and static moduli of elasticity resin-based materials. Dent. Mat., v.18, n.1, p.64-71, Jan. 2002.

118. SAHAFI, A.; PEUTZFELDT, A.; ASMUSSEN, E. Effect of pulse-delay curing on in vitro wall-to-wall contraction of composite in dentin cavity preparations. Amer. J. Dent., v.14, n.5, p.295-6, Oct. 2001.

119. SAHAFI, A.; PEUTZFELDT, A.; ASMUSSEN, E. Soft-start polymerization and marginal gap formation in vitro. Amer. J. Dent., v.14, n.3, p.145-7, June 2001.

120. SAKAGUCHI, R.L. A review of the curing mechanics of composites and their significance in dental applications. Comp. Continuing Educ. Dent., v.20, n.25, p.S16-S23, Nov. 1999.

121. SAKAGUCHI, R.L.; DOUGLAS, W.H.; PETERS, M.C.R.B. Curing light performance and polymerization of composite restorative materials. J. Dent., v.20, n.3, p.183-8, June 1992.

122. SCHILKE, R. et al. Comparison of the number and diameter of dentinal tubules in human and bovine dentine by scanning electron microscopic investigation. Arch. oral Biol., v.45, n.5, p.355-61, May 2000.

123. SCHMALZ, G. et al. Permeability characteristics of bovine and human dentin under different pretreatment conditions. J. Endod., v.27, n.1, p.23-30, Jan. 2001.

124. SCHUCKAR, M.; GEURTSEN, W. Proximo-cervical adaptation of class II-composite restorations after thermocycling. J. dent. Res., v.75, p.40, 1996. Special issue. /Abstract n. 183/

125. SCHWARTZ, J.L.; ANDERSON, M.H.; PELLEU JÚNIOR, G.B. Reducing microleakage with the glass-ionomer/resin sandwich technique. Oper. Dent., v.15, n.5, p. 186-92, Sept./Oct. 1990.

126. SHORTALL, A.C. Microleakage, marginal adaptation and composite resin restorations. Brit. dent. J., v.153, n.5, p.223-7, Sept. 1982. 
127. SHORTALL, A.C.; HARRINGTON, E.; WILSON, H.J. Light curing unit effectiveness assessed by dental radiometers. J. Dent., v.23, n.4, p.227-32, Aug. 1995.

128. SIDHU, S.K. Sealing effectiveness of light-cured glass ionomer cement liners. J. prosth. Dent., v.68, n.6, p.891-4, Dec. 1992.

129. SILIKAS, N.; ELIADES, G.; WATTS, D.C. Light intensity effects on resin-composite degree of conversion and shrinkage strain. Dent. Mat., v.16, n.4, p.292-6, July 2000.

130. SILVA, F.F. et al. Microinfiltração em diferentes tipos de cimentos de ionômero de vidro. Rev. bras. Odont., v.57, n.1, p.35-8, jan./fev. 2000.

131. SILVA E SOUZA JÚNIOR, M.H. Procedimentos restauradores estéticos em resina e porcelana para dentes posteriores. Rev. Dent. Rest., v.1, n.1, jan./ mar. 1998.

132. SILVA E SOUZA JÚNIOR, M.H.; CARVALHO, R.M.; MONDELLI, R.F.L. Odontologia Estética: fundamentos e aplicações clínicas. São Paulo, Ed. Santos, 2000.

133. SILVA E SOUZA JÚNIOR, M.H.; GONÇALVES, A.M.; MONDELLI, R.F.L. Avaliação do ionômero de vidro como material intermediário em restaurações de resina composta. Rev. bras. Odont., v.56, n.1, p.42-7, jan./fev. 1999.

134. SJÖDIN, L.; UUSITALO, M.; VAN DIJKEN, J. Resin modified glass ionomer cements. In vitro microleakage in direct class $\mathrm{V}$ and class II sandwich restorations. Swed. dent. J., v.20, n.3, p.77-86, 1996.

135. SMALL, B.W. Effects of light intensity, time, and direction on gap formation of resin composite restorations. Gen. Dent., v.47, n.5, p.460-2, Sept./ Oct. 1999.

136. SMALL, B.W. A review of devices used for photocuring resin-based composites. Gen. Dent., v.49, n.5, p.457-60, Sept./Oct. 2001.

137. STRITIKUS, J.; OWENS, B. An in vitro study of microleakage of occlusal composite restorations polymerized by a conventional curing light and a PAC curing light. J. clin. pediat. Dent., v.24, n.3, p.221-7, Spring. 2000. 
138. SUH, B.I. Controlling and understanding the polymerization shrinkage-induced stresses in light-cured composites. Comp. Continuing Educ. Dent., v.20, Suppl.n.25, p.S3441, Nov. 1999.

139. TAGAMI, J.; TAO, L.; PASHLEY, D.H. Correlation among dentin depth, permeability, and bond strength of adhesive resins. Dent. Mat., v.6, n.1, p.45-50, Jan. 1990.

140. TAPETY, C.M.C. Influência da interposição de bases na infiltração marginal em cavidades classe II (MOD), restauradas com resinas compostas para dentes posteriores. Bauru, 2001. 138p. Dissertação (Mestrado) - Faculdade de Odontologia de Bauru, Universidade de São Paulo.

141. TATE, W.H.; PORTER, K.H.; DOSCH, R.O. Successful photocuring: don't restore without it. Oper. Dent., v.24, n.2, p.109-14, Mar./Apr. 1999.

142. TAYLOR, M.J.; LYNCH, E. Microleakage. J. Dent., v.20, n.1, p.3-10, Feb.1992.

143. TAYLOR, M.J.; LYNCH, E. Marginal adaptation. J. Dent., v.21, n.5, p.265-73, Oct. 1993.

144. TJAN, A.H.L.; DUNN, J.R. Microleakage at gingival dentin margins of class V composite restorations lined with light-cured glass ionomer cement. J. Amer. dent. Ass., v.121, n.6, p.706-10, Dec. 1990.

145. TOLIDIS, K., NOBECOURT, A., RANDALL, R.C. Effect of a resin-modified glass ionomer liner on volumetric polymerization shrinkage of various composites. Dent. Mat., v.14, n.6, p. 417-23, Nov. 1998.

146. TRUSHKOWSKY, R.D.; GWINNETT, A.J. Microleakage of Class V composite, resin sandwich and resin-modified glass ionomers. Amer. J. Dent., v.9, n.3, p.96-9, June 1996.

147. UNO, S.; ASMUSSEN, E. Marginal adaptation of a restorative resin polymerized at reduced rate. Scand. J. dent. Res., v.99, n.5, p.440-4, Oct. 1991.

148. UNTERBRINK, G.L.; MUESSNER, R. Influence of light intensity on two restorative systems. J. Dent., v.23, n.3, p.183-9, June 1995. 
149. VERONEZI, M.C. Influência da ciclagem térmica e do método de avaliação na determinação da microinfiltração em restaurações de resina composta. Bauru, 2000. 222p. Tese (Doutorado) - Faculdade de Odontologia de Bauru, Universidade de São Paulo.

150. VERSLUIS, A.; TANTBIROJN, D. Theoretical considerations of contraction stress. Comp. Continuing Educ. Dent., v.20, n.25, p.S24-S32, Nov. 1999.

151. VERSLUIS, A.; SAKAGUCHI, R.L.; DOUGLAS, W.H. Post-gel shrinkage measurements by measurements by means of strain gauges. J. dent. Res., v.72, p.386, 1993. Special issue. /Abstract n.2263/.

152. VERSLUIS, A.; TANTBIROJN, D., DOUGLAS, W.H. Do dental composites always shrink toward the light? J. dent. Res., v.77, n.6, p.1435-45, June 1998.

153. WENDT, S.L.; McINNES, P.M.; DICKINSON, G.L. The effect of thermocycling in microleakage analysis. Dent. Mat., v.8, n.3, p.181-4, May 1992.

154. YAMAUTI, M. Avaliação da infiltração marginal em restaurações de resina composta empregando-se diferentes técnicas de inserção e de ativação da polimerização do material. Bauru, 1999. 141p. Dissertação (Mestrado) - Faculdade de Odontologia de Bauru, Universidade de São Paulo.

155. YAP, A.U.J.; SOH, M.S.; SIOW, K.S. Post- gel shrinkage with pulse activation and softstart polymerization, Oper. Dent., v.27, n.1, p.81-7, Jan./ Feb. 2002.

156. YAP, A.U.J. et al. Polymerization shrinkage of visible-light-cured composites. Oper. Dent., v.25, n.2, p.98-103, Mar./Apr. 2000.

157. YOSHIKAWA, T.; BURROW, M.F.; TAGAMI, J. A light curing method for improving marginal sealing and cavity wall adaptation of resin composite restorations. Dent. Mat., v.17, n.4, p.359-66, July 2001.

158. YOSHIKAWA, T.; BURROW, M.F.; TAGAMI, J. The effects of bonding system and light curing method on reducing stress of different $\mathrm{C}$-factor cavities. J. Adhes. Dent., v.3, n.2, p. 177-83, Summer 2001. 
159. YOSHIKAWA, T. et al. Effects of dentin depth and cavity configuration on bond strength. J. dent. Res., v.78, n.4, p.898-905, Apr. 1999. 


\begin{abstract}
Marginal leakage in class $V$ resin composite restorations: influence of the liner and the curing technique
\end{abstract}

The purpose of this in vitro study was to evaluate the influence of different glass ionomer cement liners and curing techniques on the microleakage of resin composite restorations. Class V root cavities were prepared in the buccal surfaces of 120 bovine incisors. The specimens were divided into twelve groups of ten each, according to the liner and to the curing technique employed. Group 1- Single Bond + Z100; group 2- RMGIC (Vitrebond) + Single Bond + Z100; group 3- conventional GIC (Ketac Bond) + Single Bond + Z100, which were light cured by conventional technique; the other groups were restored similar to groups 1, 2 and 3, respectively; although, they were light cured by ramp technique (groups 4, 5, 6); pulse technique (groups $7,8,9)$ and high intensity $(10,11,12)$. The thickness of the liner was $0.5 \mathrm{~mm}$ and the resin composite was inserted in one increment. The four curing techniques were applied with different light intensities as follows: $450 \mathrm{~mW} / \mathrm{cm}^{2} / 40 \mathrm{~s}$ (conventional), 100 $800 \mathrm{~mW} / \mathrm{cm}^{2} / 15 \mathrm{~s}+800 \mathrm{~mW} / \mathrm{cm}^{2} / 25 \mathrm{~s}(\mathrm{ramp}) ; 200 \mathrm{~mW} / \mathrm{cm}^{2} / 3 \mathrm{~s}+3$ minutes delay + $600 \mathrm{~mW} / \mathrm{cm}^{2} / 30 \mathrm{~s}$ (pulse); $1600 \mathrm{~mW} / \mathrm{cm}^{2} / 3 \mathrm{~s}$ (high intensity). After 7 days, the teeth were thermocycled (500 cycles at $5^{\circ} \mathrm{C}-55^{\circ} \mathrm{C}$ with a dwell time of 60 seconds) and immersed in aqueous solution of $0.5 \%$ basic fuchsin for $4 \mathrm{~h}$. Then, they were sectioned and the dye penetration was measured in millimeters by means of a computer program (Image Tool). Data were analyzed by two-way ANOVA and Tukey test. There were no significant differences among conventional, ramp and pulse techniques. The high intensity technique showed significant dye penetration when compared with others curing techniques. There were no significant differences in marginal leakage between the liners (conventional GIC and resin modified GIC), but the microleakage was significantly higher in the groups restored with no liner. No relationship between filling techniques and light curing methods was observed. It can be concluded that sandwich restorations were efficient in microleakage prevention, while the high intensity curing technique may lead to the highest dye penetration values in dentin cavities restored with resin composites. 